U.S. Department of the Interior

U.S. Geological Survey

\title{
Water-Quality, Biology, and Streambed Sediment Data and Preliminary Geochemical Interpretations for Streams in the Upper Prickly Pear Creek Watershed, Montana, 2000
}

Edited by Terry L. Klein ${ }^{1}$, Joanna N. Thamke ${ }^{2}$, and Aïda M. Farag ${ }^{3}$

U.S. Geological Survey, Geologic Division, Open-File Report

In cooperation with the U.S. Department of Agriculture-Forest Service

\footnotetext{
${ }^{1}$ Denver, Colorado

2 Helena, Montana

3 Jackson, Wyoming
} 
Introduction

Water-quality data for streams by Joanna N. Thamke and Sharon L. Gelinas

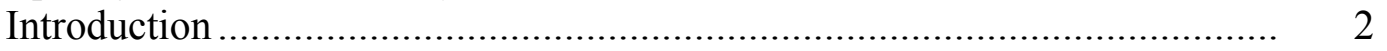

Water quality data......................................................................... 2

Sampling and processing methods ........................................... 2

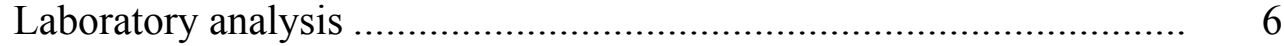

Quality-assurance data............................................................. 6

Streambed sediment data and preliminary geochemical interpretation by Terry L. Klein and David L. Fey

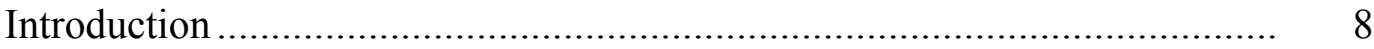

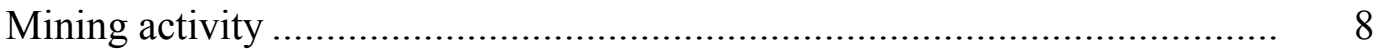

Mineral deposits, smelter and mill sites..................................................... 9

Geologic setting............................................................................ 10

Sample distribution ............................................................... 11

Total and partial-digestion metals .................................................... 12

Mercury in water survey ................................................................ 13

Sample and analytical protocol .......................................................... 13

Data tables...................................................................... 13

Streambed sediment samples .................................................. 13

Water samples for mercury analysis........................................... 13

Water samples for hardness, alkalinity and soluble and total iron analyses.................................................................... 14

Sample analysis ............................................................ 14

Total digestion of bed sediments ......................................... 14

Warm 2M HCl-1 percent $\mathrm{H}_{2} \mathrm{O}_{2}$ partial-digestion of streambed sediments ............................................................... 14

Mercury analyses of water samples ...................................... 14

Field alkalinity measurements of selected water samples ........... 15

Field hardness measurements of selected water samples ........... 15

Field measurements of total and soluble iron in selected water samples .................................................................. 15

Conductivity and $\mathrm{pH}$ field measurements of water samples ....... 15

Background sites ........................................................................ 15

Streambed sediment metal chemistry and biological screening levels........... 16

Ribbon maps.................................................................................... 18

Results of reconnaissance mercury in water survey ................................. 24

Biology data by Aida M. Farag and Bradley G. Mueller

Introduction ................................................................................ 25

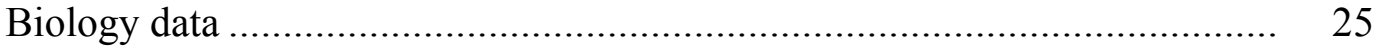

Methods ........................................................................ 25

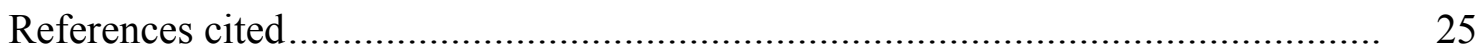

\section{FIGURES}

1. Location of the upper Prickly Pear Creek watershed and sampling sites, 
2. Boundaries of mining districts ...................................................................... 9

3. Cultural and natural features with potential effects on streambed sediment

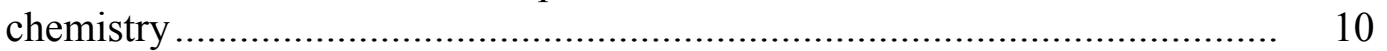

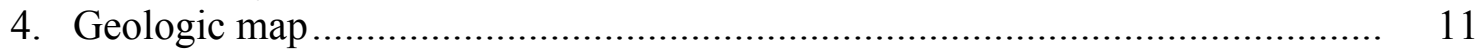

5. Location of NURE streambed samples ...................................................... 12

6. Locations of background streambed sediment sites....................................... 17

7. Population summary of base metal concentrations.......................................... 19

8. Arsenic concentrations (partial-digestion) in stream segments ......................... 20

9. Cadmium concentrations (partial-digestion) in stream segments..................... 20

10. Copper concentrations (partial-digestion) in stream segments........................... 21

11. Lead concentrations (partial-digestion) in stream segments ............................ 21

12. Zinc concentrations (partial-digestion) in stream segments .............................. 22

13. Prickly Pear stream segments that exceed CBSLC ........................................ 24

\section{TABLES}

1. Water-quality sampling sites ………..........................................................

2. Median background values of streambed sediments....................................... 16

3. Summary of provisional streambed sediment screening levels .......................... 18

\section{APPENDICES}

1. Physical properties and concentrations of selected major ions and trace elements in water samples collected from streams ....................................................... $\quad 30$

2. Concentrations of additional trace elements at periodic water-quality sites ....... 35

3. Water-quality data for field duplicates.......................................................... 36

4. Water-quality data for field blank ................................................................. 37

5. Field numbers, site descriptions, sample descriptions, latitude and longitude, and field measurements of streambed sediment localities .................................. 38

6. Mixed acid total digestion ICP-AES results from streambed sediments ............ 40

7. Results of NURE streambed sediment sample reanalysis by ICP-AES using mixed acid total digestion ......................................................................... 42

8. $2 \mathrm{M} \mathrm{HCL}-1 \%$ hydrogen peroxide (weak) partial-digestion ICP-AES results from streambed sediments 43

9. Mercury in water, filtered and unfiltered samples ........................................... 45

10. Provisional biology data from streams ........................................................ 46 
CONVERSION FACTORS, ABBREVIATED UNITS, AND ACRONYMS

\begin{tabular}{rll}
\hline Multiply & By & \multicolumn{1}{c}{ To obtain } \\
\hline cubic foot per second $\left(\mathrm{ft}^{3} / \mathrm{s}\right)$ & 0.028317 & cubic meters per second $\left(\mathrm{m}^{3} / \mathrm{s}\right)$ \\
foot (ft) & 0.3048 & meter $(\mathrm{m})$ \\
inch (in.) & 25.4 & millimeter $(\mathrm{mm})$ \\
mile (mi) & 1.609 & kilometer \\
\hline
\end{tabular}

Temperature can be converted to degrees Celsius $\left({ }^{\circ} \mathrm{C}\right)$ or degrees Fahrenheit $\left({ }^{\circ} \mathrm{F}\right)$ by the following equations:

$$
\begin{aligned}
& { }^{\circ} \mathrm{C}=5 / 9\left({ }^{\circ} \mathrm{F}-32\right) \\
& { }^{\circ} \mathrm{F}=9 / 5\left({ }^{\circ} \mathrm{C}\right)+32
\end{aligned}
$$

Sea level: In this report, "sea level" refers to the National Geodetic Vertical Datum of 1929 (NGVD of 1929) - a geodetic datum derived from a general adjustment of the first-order level nets of both the United States and Canada, formerly called Sea Level Datum of 1929.
Abbreviated units used in this report:
$\mu \mathrm{g} / \mathrm{L} \quad$ micrograms per liter
$\mu \mathrm{m} \quad$ micrometer (micron)
$\mu \mathrm{S} / \mathrm{cm} \quad$ microsiemens per centimeter at 25 degrees Celsius
$\mathrm{mg} / \mathrm{L} \quad$ milligrams per liter
mm millimeter 


\section{INTRODUCTION}

The upper Prickly Pear Creek watershed encompasses the upstream 15 miles of Prickly Pear Creek, south of Helena, Montana (fig. 1). The headwaters of Prickly Pear Creek and its tributaries (Beavertown Creek, Clancy Creek, Dutchman Creek, Golconda Creek, Lump Gulch, Spring Creek, and Warm Springs Creek) are primarily in the Helena National Forest, whereas the central part of the watershed primarily is within either Bureau of Land Management (BLM) or privately owned property. Three mining districts are in the upper Prickly Pear Creek watershed: Alhambra, Clancy, and Colorado. Numerous prospects, adits, tailings piles, mills, dredge piles, and mines (mostly inactive) are located throughout the watershed.

Hard-rock mining in the upper Prickly Pear Creek watershed began in the 1860s, peaked prior to 1900, and has been sporadic since then (Metesh and others, 1993). Gold, silver, lead, copper, zinc, and arsenic were the primary metals produced (Metesh and others, 1993). Previous investigations have identified large concentrations of metals in parts of Prickly Pear Creek and some of its tributaries ([Montana] Department of Health and Environmental Sciences, 1981; David Stiller and Assoc., OEA Research, 1983; Grotbo and Stiller, 1984; Streamworks, 1984; Olympus Environmental Science and Engineering, Inc., 1998; Harper, 1999; Olympus Technical Services, Inc., 2000). However, these investigations did not address the cumulative effects of mining at a watershed scale.

As part of a cooperative effort with Federal land management agencies, the U.S. Geological Survey (USGS) is currently using an integrated approach to investigate two mining impacted watersheds in the western United States (the Animas River in Colorado and the Boulder River in Montana). These studies provide the USDA-Forest Service (USFS) and USDOI Bureau of Land Management (BLM) scientific data for implementing informed land-management decisions regarding cleanup of abandoned mine lands within each watershed. A similar integrated-science approach will be used to characterize the upper Prickly Pear Creek watershed with respect to water and streambedsediment chemistry, aquatic biota, and the geologic and geochemical framework. This integrated database and preliminary stream bed-sediment interpretations can be used to identify important pathways of metals movement and biological impacts, thereby guiding resource-management decisions of land management agencies. Watershed-level characterization will facilitate determinations of whether removal of contaminated materials or other cleanup activities are necessary, planning of short- and long-term restoration efforts, and development of a monitoring plan to document cleanup effectiveness. 


\title{
WATER-QUALITY DATA FOR STREAMS IN THE UPPER PRICKLY PEAR CREEK WATERSHED, MONTANA
}

\author{
By Joanna N. Thamke and Sharon L. Gelinas
}

\section{INTRODUCTION}

This section presents hydrologic data that were collected by the in the upper Prickly Pear Creek watershed during the period June through October 2000. Data presented include measurements of streamflow quantity and quality, and qualityassurance data.

A site number is used as the primary identification for sample sites (fig. 1, table 1). This alpha-numeric identification allows cross reference between tables and figures. The alpha character denotes the first letter of the stream name. The numeric characters denote the downstream sequence, beginning at the most upstream site. In addition, each site is assigned an eight-digit or fifteen-digit station-identification number (table 1). Eight-digit station-identification numbers represent the standard USGS numbering system for streamflow-gaging stations or routine streamflow-measurement sites. Fifteendigit station-identification numbers are used for miscellaneous or temporary surfacewater stations. The fifteen-digit numbers represent the approximate latitude and longitude of the site (first 13 digits), plus the sequence number (last 2 digits).

\section{WATER-QUALITY DATA}

Water-quality samples were collected at 37 sites (table 1, fig. 1) from June through October 2000. Water-quality data for field parameters (specific conductance, $\mathrm{pH}$ ), hardness, selected trace elements, and suspended sediment are presented in Appendix 1. Sample sites were located throughout the watershed. Five of the sites (C5, L5, PP-3, PP-5, and WS-3) were sampled periodically as part of a routine sampling program to characterize seasonal variability in water quality, including a more comprehensive analysis of trace element concentrations (Appendix 2).

\section{Sampling and Processing Methods}

Composite water samples for measurements of physical properties and analyses of chemical constituents were collected from multiple verticals across the stream using depth- and width-integration methods described by Knapton (1999) and Edwards and Glysson (1999). These methods provide an instantaneous mean discharge-weighted sample that is representative of the entire stream. Sampling equipment consisted of standard USGS depth-integrating suspended samplers (DH-81 and DH-48), which are constructed of plastic or coated with non-metallic epoxy paint, and equipped with a $5 / 16^{-}$ inch nylon nozzle (Edwards and Glysson, 1999). Grab samples were collected when streamflow was too low to allow use of the depth-integrated sampler. 
Figure 1. Location of the upper Prickly Pear Creek watershed and sampling site, Montana

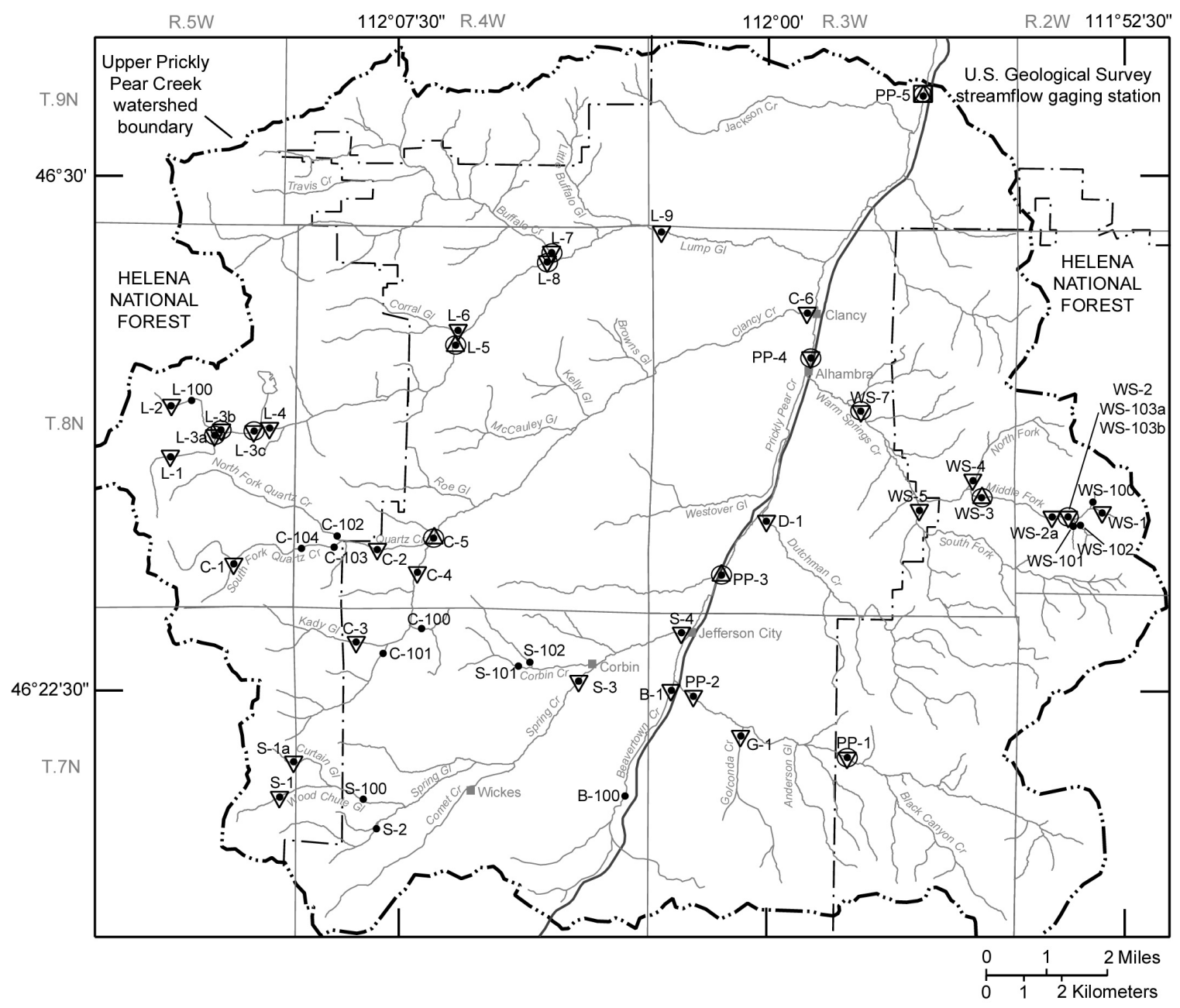

EXPLANATION SITE TYPE AND NUMBER

${ }^{\mathrm{S}-1} \nabla \quad$ Water Quality

PP-3 $\triangle$ Periodic Water Quality

S-100 Streambed Sediment

${ }^{\text {PP- }} 5 \square$ Continuous-record streamflow

${ }^{\mathrm{C}-5} \bigcirc$ Biology

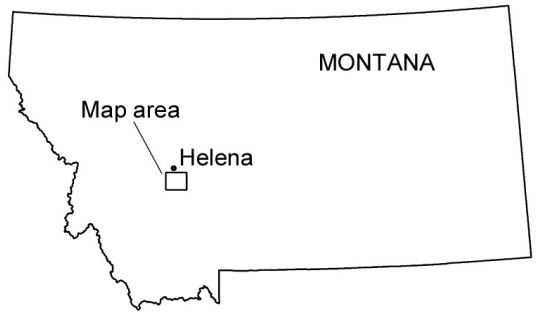


Table 1. Water-quality sampling sites in the upper Prickly Pear Creek watershed, Montana, 2000

Latitude Longitude

\begin{tabular}{|c|c|c|c|c|c|c|c|c|c|c|}
\hline $\begin{array}{c}\text { Site } \\
\text { number } \\
\text { (fig. 1) }\end{array}$ & $\begin{array}{c}\text { Station identification } \\
\text { number }\end{array}$ & Station name & $\begin{array}{c}\text { Altitude } \\
\text { (feet) }\end{array}$ & d & $\mathbf{m}$ & $\mathbf{s}$ & d & m & $\mathbf{s}$ & Topographic map \\
\hline B-1 & 462234112014001 & Beavertown Creek above Prickly Pear Creek, near Jefferson City & 4,642 & 46 & 22 & 34 & 112 & 01 & 50 & Jefferson City \\
\hline $\mathrm{C}-1$ & 462421112105101 & Unnamed tributary above South Fork Quartz Creek, near Jefferson City & 6,460 & 46 & 24 & 17 & 112 & 10 & 57 & Chessman Reservoir \\
\hline $\mathrm{C}-2$ & 462429112080301 & Quartz Creek above Clancy Creek, near Jefferson City & 5,400 & 46 & 24 & 29 & 112 & 08 & 04 & Chessman Reservoir \\
\hline $\mathrm{C}-3$ & 462308112082901 & Kady Gulch above Clancy Creek, near Jefferson City & 5,760 & 46 & 23 & 08 & 112 & 08 & 29 & Chessman Reservoir \\
\hline $\mathrm{C}-4$ & 462417112070801 & Clancy Creek above Quartz Creek, near Jefferson City & 5,226 & 46 & 24 & 08 & 112 & 07 & 10 & Jefferson City \\
\hline $\mathrm{C}-5$ & 462449112064301 & Clancy Creek below Quartz Creek, near Jefferson City ${ }^{1,2,3,4}$ & 5,040 & 46 & 24 & 40 & 112 & 06 & 50 & Jefferson City \\
\hline C-6 & 06060000 & Clancy Creek at Clancy, Mont. & 4,223 & 46 & 27 & 57 & 111 & 59 & 08 & Clancy \\
\hline D-1 & 462500111595901 & Dutchman Creek above Prickly Pear Creek, near Jefferson City & 4,418 & 46 & 25 & 00 & 111 & 59 & 59 & Clancy \\
\hline G-1 & 462156112002301 & Golconda Creek, above Prickly Pear Creek, near Jefferson City & 4,800 & 46 & 21 & 56 & 112 & 00 & 23 & Wickes \\
\hline L-1 & 462544112122201 & Lump Gulch above meadows, near Clancy & 6,690 & 46 & 25 & 45 & 112 & 12 & 22 & Chessman Reservoir \\
\hline $\mathrm{L}-2$ & 462633112122701 & Lump Gulch above Nellie Grant Mill, near Clancy & 6,960 & 46 & 26 & 29 & 112 & 12 & 23 & Chessman Reservoir \\
\hline L-3a & 462603112112101 & Lump Gulch tributary 1 below Frohner Meadow, near Clancy ${ }^{2,3}$ & 6,480 & 46 & 26 & 03 & 112 & 11 & 21 & Chessman Reservoir \\
\hline $\mathrm{L}-3 \mathrm{~b}$ & 462612112111501 & Lump Gulch tributary 2 below Frohner Meadows, near Clancy ${ }^{2}$ & 6,480 & 46 & 26 & 12 & 112 & 11 & 16 & Chessman Reservoir \\
\hline $\mathrm{L}-3 \mathrm{c}$ & 462609112103201 & Lump Gulch above Park Lake, near Clancy ${ }^{2,3}$ & 6,200 & 46 & 26 & 07 & 112 & 10 & 36 & Chessman Reservoir \\
\hline $\mathrm{L}-4$ & 462615112102201 & Lump Gulch below Park Lake, near Clancy & 6,190 & 46 & 26 & 12 & 112 & 10 & 20 & Chessman Reservoir \\
\hline $\mathrm{L}-5$ & 462733112062201 & Lump Gulch above Corral Gulch, near Clancy ${ }^{1,2,3,4}$ & 5,120 & 46 & 27 & 27 & 112 & 06 & 24 & Jefferson City \\
\hline L-6 & 462733112061701 & Corral Gulch above Lump Gulch, near Clancy & 5,120 & 46 & 27 & 37 & 112 & 06 & 19 & Jefferson City \\
\hline $\mathrm{L}-7$ & 462840112042701 & Lump Gulch above Buffalo Creek, near Clancy ${ }^{2,3}$ & 4,640 & 46 & 28 & 39 & 112 & 04 & 30 & Jefferson City \\
\hline $\mathrm{L}-8$ & 462841112042601 & Buffalo Creek above Lump Gulch, near Clancy ${ }^{3}$ & 4,640 & 46 & 28 & 43 & 112 & 04 & 27 & Jefferson City \\
\hline L-9 & 462900112020001 & Lump Gulch below Little Buffalo Gulch, near Clancy & 4,360 & 46 & 29 & 05 & 112 & 02 & 16 & Jefferson City \\
\hline PP-1 & 462134111582301 & Prickly Pear Creek above Golconda Creek, near Jefferson City ${ }^{2,3,4}$ & 5,360 & 46 & 21 & 33 & 111 & 58 & 12 & Elkhorn \\
\hline PP-2 & 462228112012101 & Prickly Pear Creek above Beavertown Creek, near Jefferson City & 4,680 & 46 & 22 & 27 & 112 & 01 & 26 & Wickes \\
\hline PP-3 & 462352112010201 & Prickly Pear Creek near Jefferson City ${ }^{1,2,3,4}$ & 4,480 & 46 & 24 & 07 & 112 & 00 & 52 & Jefferson City \\
\hline PP-4 & 462718111590501 & Prickly Pear Creek at Alhambra RV Park, near Clancy ${ }^{3}$ & 4,240 & 46 & 27 & 18 & 111 & 59 & 03 & Clancy \\
\hline PP-5 & 06061500 & Prickly Pear Creek near Clancy ${ }^{1,2,3}$ & 4,067 & 46 & 31 & 09 & 111 & 56 & 45 & East Helena \\
\hline S-1 & 462052112100001 & Wood Chute Gulch above Spring Creek, near Jefferson City & 6,530 & 46 & 20 & 52 & 112 & 10 & 00 & Mt. Thompson \\
\hline S-1a & 462122112094301 & Curtain Gulch above Wood Chute Gulch near Jefferson City & 6,750 & 46 & 21 & 22 & 112 & 09 & 43 & Mt. Thompson \\
\hline
\end{tabular}


Table 1. Water-quality sampling sites in the upper Prickly Pear Creek watershed, Montana, 2000 (Continued)

Latitude Longitude

\begin{tabular}{|c|c|c|c|c|c|c|c|c|c|c|}
\hline \multirow[b]{2}{*}{$\begin{array}{c}\text { Site } \\
\text { number } \\
\text { (fig. 1) }\end{array}$} & \multirow[b]{2}{*}{$\begin{array}{c}\text { Station identification } \\
\text { number }\end{array}$} & \multirow[b]{2}{*}{ Station name } & \multicolumn{4}{|c|}{ Latitude } & \multicolumn{3}{|c|}{ Longitude } & \multirow[b]{2}{*}{ Topographic map } \\
\hline & & & $\begin{array}{l}\text { Altitude } \\
\text { (feet) }\end{array}$ & d & $\mathbf{m}$ & $\mathbf{s}$ & d & $\mathbf{m}$ & $\mathbf{s}$ & \\
\hline S-2 & 462025112075501 & Spring Gulch above Spring Creek, near Jefferson City & 5,640 & 46 & 20 & 28 & 112 & 07 & 56 & Mt. Thompson \\
\hline S-3 & 462234112031201 & Spring Creek above Prickly Pear Creek, near Jefferson City & 4,800 & 46 & 22 & 35 & 112 & 03 & 48 & Jefferson City \\
\hline S-4 & 462320112012901 & Spring Creek at Jefferson City & 4,558 & 46 & 23 & 20 & 112 & 01 & 38 & Jefferson City \\
\hline WS-1 & 462509111530001 & Middle Fork Warm Springs Creek above mines, near Clancy & 5,600 & 46 & 25 & 10 & 111 & 53 & 02 & Clancy \\
\hline WS-2 & 462502111533801 & Middle Fork Warm Springs Creek below mines, near Clancy ${ }^{3}$ & 5,381 & 46 & 25 & 02 & 111 & 53 & 38 & Clancy \\
\hline WS- $2 \mathrm{a}$ & 462504111534901 & Middle Fork Warm Springs Creek below tailings, near Clancy & 5,295 & 46 & 25 & 04 & 111 & 53 & 49 & Clancy \\
\hline WS-3 & 462521111552101 & Middle Fork Warm Springs Creek near Clancy ${ }^{1,3,4}$ & 4,800 & 46 & 25 & 21 & 111 & 55 & 40 & Clancy \\
\hline WS-4 & 462528111554301 & North Fork Warm Springs Creek above Warm Springs Creek, near Clancy & 4,801 & 46 & 25 & 29 & 111 & 55 & 44 & Clancy \\
\hline WS-5 & 462511111563301 & South Fork Warm Springs Creek near Clancy & 4,594 & 46 & 25 & 11 & 111 & 56 & 44 & Clancy \\
\hline WS-7 & 462635111575701 & Warm Springs Creek above Prickly Pear Creek, near Clancy ${ }^{2,3}$ & 4,500 & 46 & 26 & 33 & 111 & 58 & 01 & Clancy \\
\hline
\end{tabular}

${ }^{1}$ Site sampled periodically as part of routine water quality sampling program.

${ }^{2}$ Site sampled as part of biology sampling program ñ aquatic vegetation.

${ }^{3}$ Site sampled as part of biology sampling program ñ benthic macroinvertebrates.

${ }^{4}$ Site sampled as part of biology sampling program ñ fish tissues.

NOTE: Biofilm (aufwuchs) samples also collected from sites PP4 and WS7. 
Field measurements of specific conductance, $\mathrm{pH}$, and water temperature were made during sample collection. Samples were processed according to procedures described by Horowitz and others (1994), Ward and Harr (1990), and Knapton (1985). Samples for dissolved constituents were filtered using a $0.45-\mu \mathrm{m}$ pore size filter. Instantaneous streamflow at the time of sample collection was determined by stagedischarge rating at PP-5 (gage station) and by direct measurement (Rantz and others, 1982) at all other sites.

\section{Laboratory Analysis}

Trace elements selected for analysis were similar to those analyzed for another abandoned mine lands study in the Boulder River watershed, Montana. Trace elements in the Boulder River watershed that consistently had concentrations less than the minimum reporting level (Nimick and Cleasby, 2000) were not analyzed. Analysis of an extensive suite of trace elements from five periodic sites in October 2000 confirmed nondetectable concentrations for the omitted elements in the upper Prickly Pear Creek watershed (table 3).

The USGS National Water Quality Laboratory (NWQL) in Denver, Colo., analyzed water samples for trace elements according to methods described by Fishman and Freidman (1989), Patton and Truitt (1992), Faires (1993), Fishman (1993), Hoffman and others (1996), Garbarino and Struzeski (1998), Garbarino (1999), and Jones and Garbarino (1999). The USGS Montana District sediment laboratory in Helena, Mont., analyzed water samples for suspended-sediment concentration and the percentage of suspended sediment finer than 0.062-mm diameter (silt size and smaller) according to methods described by Guy (1969) and Lambing and Dodge (1993).

\section{Quality-Assurance Data}

Data-collection and analytical procedures used in this study incorporate practices designed to control, verify, and assess the quality of sample data. Quality-assurance procedures used for the collection and field processing of water-quality samples are described by Knapton (1985), Ward and Harr (1990), Knapton and Nimick (1991), Horowitz and others (1994), and Edwards and Glysson (1999). Standard procedures used by the NWQL for internal sample handling and quality assurance are described by Friedman and Erdmann (1982), Jones (1987), and Pritt and Raese (1995). The Montana District sediment laboratory uses quality-assurance procedures described by Lambing and Dodge (1993).

Duplicate samples are two samples considered essentially identical in composition. Duplicate samples were obtained in the field by splitting a single sample into two subsamples, which then were analyzed separately. Analyses of field duplicates are presented in Appendix 3.

A blank sample of deionized water was routinely analyzed to identify the presence and magnitude of contamination that potentially could bias analytical results. The particular type of blank sample routinely tested was a "field" blank. A field blank is an aliquot of deionized water, which is certified as trace element free and is processed through the sampling equipment used to collect stream samples. The blank is then subjected to the same processing (filtration, preservation, transportation, and laboratory handling) as stream samples. The blank sample was analyzed for the same constituents 
as those of stream samples to identify whether any detectable concentrations exist. Analytical results for a field blank are presented in Appendix 4.

The USGS NWQL collects quality-control data on a continuing basis to evaluate selected analytical methods to determine laboratory reporting levels (LRL's).

Accordingly, concentrations are reported as $<$ LRL for samples in which the analyte was either not detected or did not pass identification. Analytes that are detected at concentrations less than LRL and that pass identification criteria are estimated.

Estimated concentrations will be noted with a remark code of "E." These data should be used with the understanding that their uncertainty is greater than that of data reported without the "E" remark code. 


\title{
STREAMBED SEDIMENT DATA AND PRELIMINARY GEOCHEMICAL INTERPRETATION FOR STREAMS IN THE UPPER PRICKLY PEAR CREEK WATERSHED, MONTANA
}

\author{
By Terry L. Klein and David L. Fey
}

\section{INTRODUCTION}

This section presents descriptions of sample sites, geochemical data, and preliminary data interpretations of a streambed sediment sampling program and a reconnaissance dissolved- and suspended- mercury in water survey undertaken in early October 2000. This sampling program was designed to examine the concentrations of ore-related metals in streambed sediment and to understand their sources. The mercury survey was undertaken to determine whether mercury transport was occurring in stream water. The results of re-analyses of streambed sediments from an earlier Department of Energy sampling program by more sensitive methods are also tabulated. These samples were collected during the mid-1970's as part of the National Uranium Resource Evaluation (NURE) program (Aamodt, 1978; Broxton, 1980).

Chemical concentrations in streambed sediments represent: 1) the composition of the underlying bedrock and glacial deposits at and above the sample site 2) input from natural or anthropogenic point sources, for example naturally outcropping mineral deposits, or abandoned or active mines and mills. These sediments represent a timeintegrated view of the chemical input from these sources. Stream water chemistry is related to interaction of water with bedrock and its weathering products such as soil and streambed sediment; many of the process are governed by the $\mathrm{pH}$ (acidity) and Eh (oxidation potential) of the water. One important intermediate source of metal in water is metal loosely held in colloidal sediment grain coatings such as manganese and iron oxyhydroxides. These deposits can rapidly interchange metals with water governed by modest changes in water chemistry or during bed sediment transport. Bed sediment composition is also important because it may directly affect the health and metal content of benthic fauna, which are a primary food source for fish.

\section{MINING ACTIVITY}

Mining activity in the upper part of Prickly Pear Creek began in 1864 near the headwaters of Clancy Creek (Roby and others, 1960). Since that time metal production has occurred throughout most of the upper Prickly Pear Creek watershed, with most of the metal production taking place during three time periods: 1) 1870-1893; 2) 1900-1930 3); 1940-1960. Recent periods of gold mining have been restricted to the upper Spring Creek drainage (Montana Tunnels) and upper Golconda Creek.

The approximate areas of mining activity are shown in figure 2. The Clancy district includes many mines from near the town of Clancy, westward to the upper part of Lump Gulch. Mines in the district have produced mainly silver, lead, and zinc. Mines in the Warm Springs-Alhambra district are found along Warm Springs Creek and have produced primarily silver and zinc, with minor gold and lead. The Golconda district is a small district located along Golconda Creek that has produced minor amounts of silver, lead and gold. Mines in the Colorado-Wickes district have produced the largest volume of ore. Three types were produced: 1) gold and copper, 2) silver and lead, 3) gold. 
Zinc was not typically mined for or recovered prior to flotation technology (circa 1917 ) and, as a result, zinc may be abundantly present in mine waste piles

Figure 2. Approximate boundaries of mining districts in the upper Prickly Pear Creek drainage watershed.

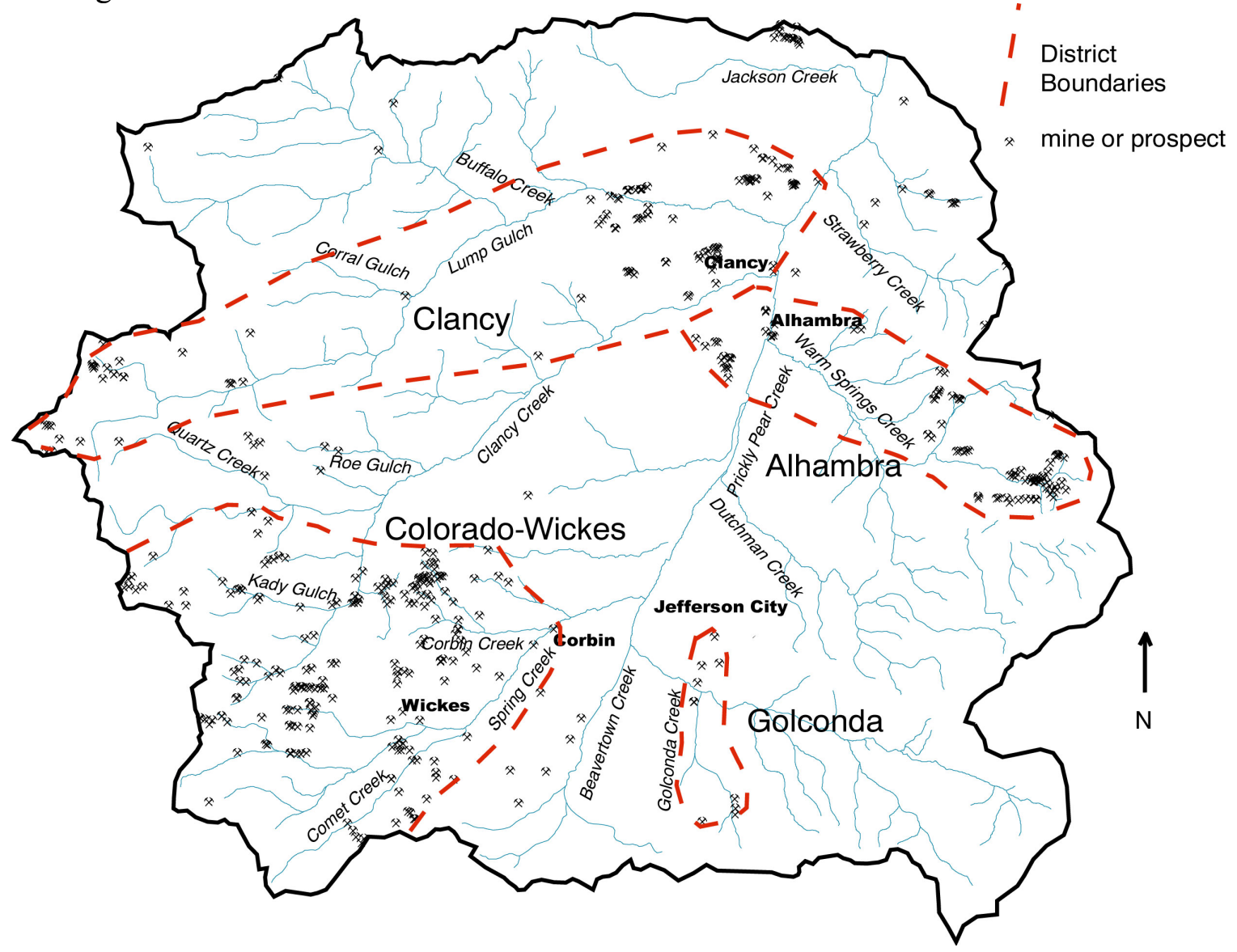

\section{MINERAL DEPOSITS, SMELTER AND MILL SITES}

A number of cultural and natural features within the drainage may potentially affect the chemistry of the streambed sediments and water. These are summarized in figure 3. Seven major mill sites processed ore from multiple sources. These may represent point sources of metals because the tailings material may contain metals remaining after incomplete extraction. This, coupled with the fine grain size makes the tailings particles susceptible to leaching. In addition, many of these older tailings impoundments have been breached during periods of high water flow and their tailings have been distributed downstream as fluvial deposits. A smelter at Wickes operated in the late 1800's and may represent a potential source of high levels of metals (Roby and others, 1960). Many of the larger streams in the basin were mined for gold placer deposits. While gold placer deposits and the mining methods used to extract them typically are not sources of other metals, the tailings left from mining alter the sediment characteristics and may disrupt the stream courses and local gradients. This may alter the metal concentrations in the streams, due to settling of colloid-trapped metals in reaches of low energy. Several areas in figure 3 are underlain by hydrothermally altered rocks or possibly porphyry copper deposits (Becraft and others, 1963; Tysdale and others, 1996). 
The bedrock and streams draining them may contain natural enrichments in copper, molybdenum, lead and zinc that are unrelated to mining activity. When hydrothermal alteration is severe, bedrock is leached of acid-neutralizing minerals and may lose the ability to naturally buffer the acidity of surface water. If these areas are coincident with areas of past mining, then acid mine drainage will not be mitigated as much as in unaltered areas, resulting in potentially higher acidity of streams in these areas.

Figure 3. Cultural and natural features with potential effects on streambed sediment chemistry in the upper Prickly Pear Creek watershed.

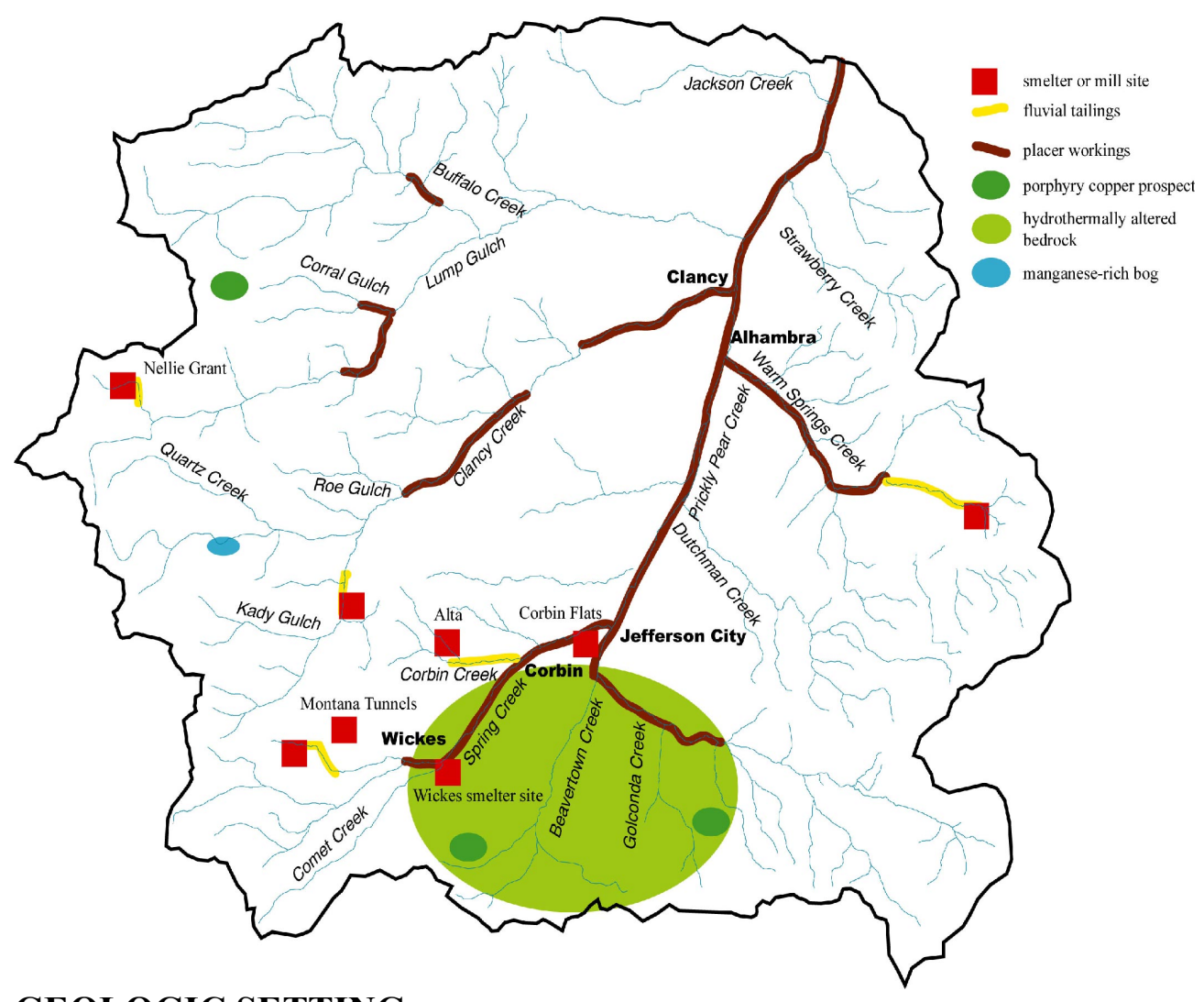

\section{GEOLOGIC SETTING}

The Prickly Pear Creek watershed lies nearly completely within rocks of the late Cretaceous Boulder batholith (fig. 4) (Becraft, and others, 1963; Smedes, 1966). Minor amounts of Paleozoic and Mesozoic sedimentary rocks are found along the northeast boundary of the watershed. The Butte Quartz Monzonite and related igneous plutonic rocks underlie more than $80 \%$ of the watershed; the Elkhorn Mountains Volcanics, a genetically related and geochemically similar sequence of volcanic rocks, comprise most of the remainder. A small enclave of the Eocene Lowland Creek Volcanics of quartz latite composition overlies the Elkhorn Mountains Volcanics in the southwestern part of the watershed. These volcanic rocks and a few scattered small rhyolitic volcanic domes or shallow intrusions of presumed Tertiary-age are also generally similar in bulk chemistry to rocks of the Boulder batholith.

Bedrock geochemistry is a major control on streambed sediment chemistry. The distribution of streambed sediment sample sites is shown in figure 4 . Because the 
composition of about $90 \%$ of the bedrock in this watershed is similar, much of the variation in the streambed sediments likely originates from point source natural features such as outcropping mineral deposits or anthropogenic features such as mine and mill sites.

Figure 4. Geologic map of the Prickly Pear Creek watershed showing location of streambed sediment sample sites. Adapted from Tysdale and others (1996).

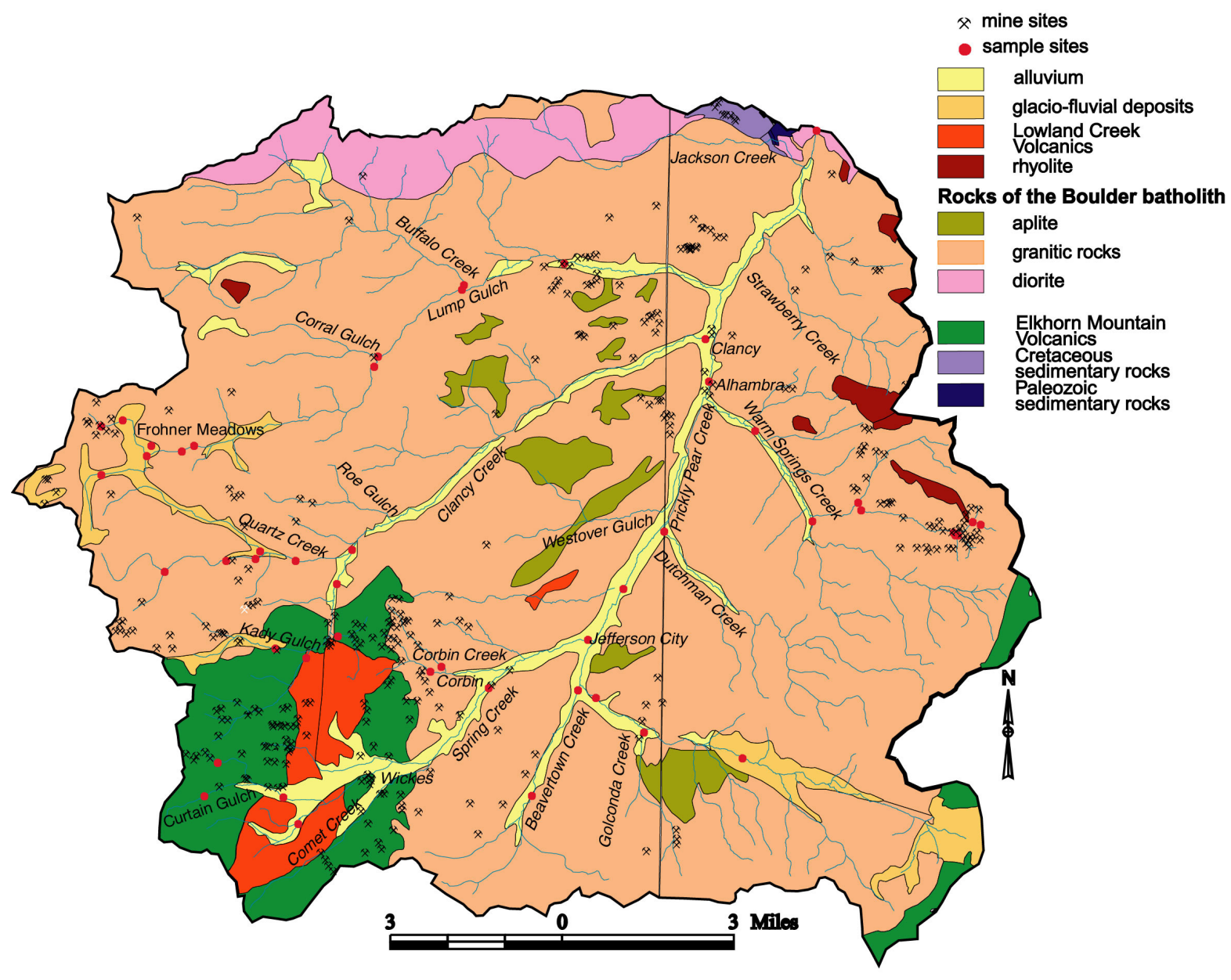

\section{SAMPLE DISTRIBUTION}

The location of 50 steambed sediment samples from the October 2000 sampling program is shown in figures 1 and 4 . The locations of the 122 NURE streambed sediment samples found within the basin are shown in figure 5 . For reference, the locations of metal mines and prospects are also indicated. In general, most areas of high concentrations of mine workings were sampled in October of 2000, along with some areas with little mining history. Five samples were collected along the main stem of Prickly Pear Creek, twelve samples were collected from Lump Gulch and its tributaries, 
eleven samples were collected from Clancy Creek and its tributaries, eight samples from Spring Creek and its tributaries, and ten samples were collected from Warm Springs Creek. Two streambed sediment samples were collected from Beavertown Creek, and one each were collected from Dutchman Creek and Golconda Creek.

Figure 5. Location of NURE streambed sediment samples in the upper Prickly Pear Creek watershed

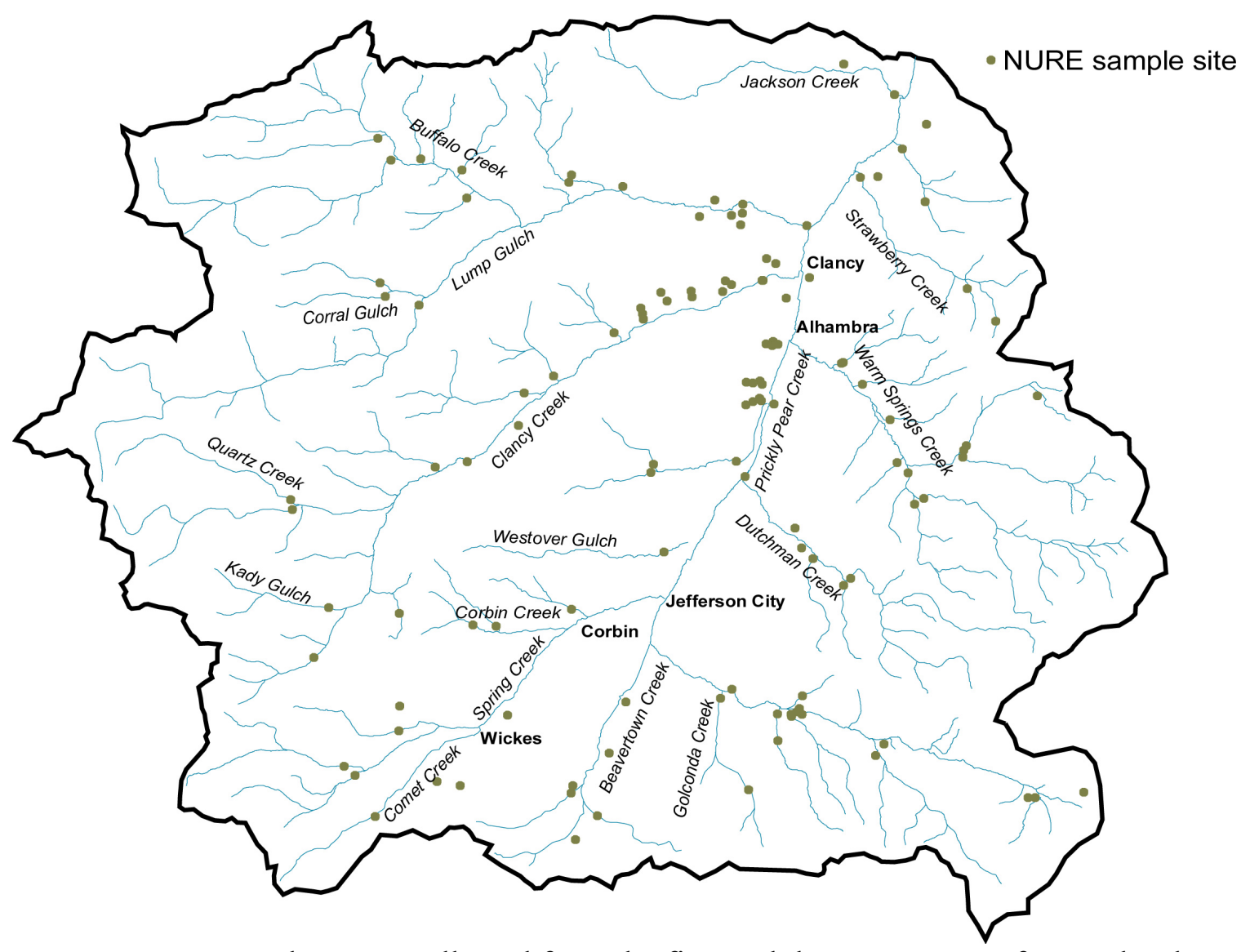

NURE samples were collected from the first and the upper parts of second order streams; none were taken along Prickly Pear Creek except near the headwaters. Many small streams were sampled in the Clancy area. Some of these were sampled at very small intervals in order to evaluate the area for the presence of uranium deposits.

\section{TOTAL AND PARTIAL-DIGESTION METALS}

Sample collected in October 2000 were analyzed using two different digestions. A four acid digestion is used to determine the "total" amount of metal in the mineral grains that comprise the sediment and metal present as grain coatings. A weak acidperoxide partial-digestion is used to determine the amount of loosely held (easily leachable) metals that are present mainly in grain coatings.

The "total" metal values reflect the composition of the mineral grains, the bulk of which represent the rock-forming and resistant minerals from the source area. These total metal values also include the metal found in the less stable grain coatings. 
Loosely held metals recovered by the partial-digestion are found primarily in manganese and iron oxy-hydroxide coatings on the sediment grains.

\section{MERCURY IN WATER SURVEY}

Seventeen sample sites were selected from the 50 streambed sediment sample locations for reconnaissance mercury in water survey. These sites were chosen to determine whether mercury is transported in water in dissolved form or with finely divided (colloidal) material in Prickly Pear Creek watershed. Several sites were located immediately below each of the major areas of historic mining. Additional sites were located within areas that had been extensively placer mined (see fig. 3).

\section{SAMPLE AND ANALYTICAL PROTOCOL}

\section{Data tables}

Tabulated field and chemical data from streambed sediments are presented in Appendices 5-9 and as separate Excel spreadsheets. Appendix 5 contains field observations and locations of samples. Locations from the October 2000 sampling program were obtained from Global Positioning System (GPS) readings and transferred to a Geographic Information Systems (GIS) layer. GPS locations used the NAD 27 datum. Digital raster graphics (DRG) topographic maps were then registered to the layer and the locations were checked against the topography for accuracy. Several GPS site locations were revised and reconciled with site locations on the DRG topographic maps based on field observations.

\section{Streambed sediment samples}

All samples were collected from the upper part of Prickly Pear Creek and its tributaries (fig. 1). The sample sites are located on the Chessman Reservoir, Clancy, Jefferson City, Wickes, East Helena, Elkhorn and Mt. Thompson, Montana USGS 1:24,000 topographic maps.

An integrated streambed sediment sample was collected from the active alluvial channel at each site by combining 10 to 20 individual sub sites within $15 \mathrm{~m}(50 \mathrm{ft}$.) of the plotted site. In the field, each composite sample was sieved through a $2 \mathrm{~mm}$ (10 mesh) stainless steel screen, and the minus- $2 \mathrm{~mm}$ fraction retained; the larger fractions were discarded.

Streambed sediment samples were air-dried at ambient room temperature $\left(25^{\circ} \mathrm{C}\right)$ and sieved to minus-80-mesh $(<0.18 \mathrm{~mm})$ prior to laboratory analyses.

\section{Water samples for mercury analysis}

Water samples were collected for mercury analyses at seventeen sites. Both filtered and unfiltered samples were collected and preserved in pre-cleaned glass bottles with five percent of a one percent-sodium dichromate/concentrated ultra-pure nitric acid solution. We used a $30 \mathrm{ml}$ disposable syringe mounted with a disposable $0.45 \mu \mathrm{m}$ filter to collect filtered samples. 


\section{Water samples for hardness, alkalinity, and soluble and total iron analyses}

Water samples for these parameters were collected and analyzed in the field at selected sites; no samples were returned to the laboratory for additional work.

\section{Sample Analysis}

\section{Total- digestion of streambed sediments}

The streambed sediment samples were digested with a mixed-acid procedure consisting of $\mathrm{HCl}, \mathrm{HNO}_{3}, \mathrm{HClO}_{4}$, and $\mathrm{HF}$. Results are reported for 34 elements analyzed by inductively coupled plasma-atomic emission spectroscopy (ICP-AES) (Crock and others, 1983; Briggs, 1996). This procedure is effective in dissolving most minerals, including silicates, oxides and sulfides; however, resistant or refractory minerals such as zircon, chromite, and some tin oxides are only partially dissolved. Previous investigations using a variety of materials support the completeness of the digestion (Church and others, 1987; Wilson and others, 1994). Limits of determination for the total digestion method are given in table 5 of Fey and others (1999a). A statistical summary of mean values, standard deviations, and median values for four National Institute of Standards and Technology (NIST) standard reference materials (SRM-2704, SRM-2709, SRM-2710, and SRM-2711) analyzed with samples from the Boulder River watershed Abandoned Mine Lands Initiative study is contained in table 6 of Fey and others, (1999a). Comparisons with certified values for these standards (NIST, 1993a, 1993b, 1993c and 1993d) are also in Fey and others, (1999a). The results of these analyses in the upper Prickly Pear Creek watershed are in Appendix 6. Reanalysis of a subset of NURE samples within the basin was completed using this analytical protocol; the results are shown in Appendix 7.

\section{Warm 2M HCl-1 percent $\mathrm{H}_{2} \mathrm{O}_{2}$ partial-digestion of bed sediments}

The use of a partial-digestion enables one to determine concentrations of trace elements bound within different mineral phases, whereas a total-digestion releases all trace elements in a sample (Chao, 1984). The streambed sediments were subjected to a partialdigestion consisting of warm $\left(50^{\circ} \mathrm{C}\right) 2 \mathrm{M} \mathrm{HCl}-1$ percent $\mathrm{H}_{2} \mathrm{O}_{2}$ for three hours with continuous agitation; the leachates were subsequently analyzed by ICP-AES for 32 elements. This partial-digestion releases trace elements associated with hydrous amorphous iron- and manganese-oxide mineral coatings and colloidal particles (Appendix III of Church and others, 1993; Church and others, 1997). Mineral coatings such as those observed in the study area can contain a significant percentage of the trace elements in a sample (Church and others, 1997; Fey and Church, 1998; Fey and others, 1999b; 2000). Analytical limits of determination for the partial-digestion method are shown in table 5 of Fey and others (1999a). A statistical summary of mean values, standard deviations, and median values obtained from the partial-digestion procedure for the same four National Institute of Standards and Technology standard reference materials (SRM-2704, SRM2709, SRM-2710, and SRM-2711) is in table 8 of Fey and others, (1999a). The results of the partial-digestions analyses are shown in Appendix 8.

\section{Mercury analyses of water samples}

In the laboratory, all water samples, both filtered and unfiltered, were mixed with stannous chloride ( $\mathrm{SnCl}_{2}$, a reducing agent). Mercury (II) was reduced to $\mathrm{Hg}^{\mathrm{O}}$ in a flow 
injection manifold; mercury vapor was measured using flow injection cold vapor-atomic fluorescence spectrometry (CV-FAAS) (Hageman, 2001). The results of these analyses are shown in Appendix 9.

\section{Field alkalinity measurements of selected water samples}

Alkalinity measurements on selected water samples were performed in the field using Chemetrics ampoules, where an acid titrant and a mixed $\mathrm{pH}$ indicator are mixed with the sample (APHA, 1995). The results, expressed in ppm calcium carbonate $\left(\mathrm{CaCO}_{3}\right)$, are in Appendix 5.

\section{Field hardness measurements of selected water samples}

Hardness measurements of selected water samples were conducted using a Chemetrics kit. This procedure employs the titration of ethylene-diaminetetraacidic acid (EDTA) with sample water. EDTA forms a colored soluble complex with calcium and magnesium ions (APHA, 1995). The results, expressed in ppm calcium carbonate $\left(\mathrm{CaCO}_{3}\right)$, are in Appendix 5.

\section{Field measurements of total and soluble iron in selected water samples}

A colorimetric method using a Chemetrics kit was used to analyze for iron in field water samples. To measure for total iron, thioglycolic acid is added to the sample, reducing ferric iron $\left(\mathrm{Fe}^{3}\right)$ to soluble ferrous iron $\left(\mathrm{Fe}^{2}\right)$. The reduced iron reacts with 1,10 phenanthroline to form a red-colored chelate, whose darkness is dependent on the concentration of iron (APHA, 1995). To measure for soluble $\left(\mathrm{Fe}^{2}\right)$ iron, the sample is mixed with the 1,10 phenanthroline without adding the thioglycolic acid; thus only the sample's original ferrous iron reacts with the chelating agent, and the ferric iron is not measured. The results, expressed as ppm $(\mathrm{mg} / \mathrm{L})$ are in Appendix 5.

\section{Conductivity and $p H$ field measurements of water samples}

Conductivity and $\mathrm{pH}$ were measured using temperature-compensated instruments calibrated daily with solutions of the appropriate range. The results, expressed as microsiemens/centimeter $(\mu \mathrm{S} / \mathrm{cm})$ and standard $\mathrm{pH}$ units are in Appendix 5.

\section{BACKGROUND SITES}

In order to interpret the results of the chemical analysis of the streambed sediments in a regional context, the chemical elements in each sample must be compared to some value that is characteristic of "normal" streambed sediment within the drainage basin. Sample sites for background calculation were chosen from streams that drain areas with little or no mining history and that represent typical bedrock in the basin. Six sites identified during the October 2000 sampling program were used to determine the easily leachable metal background values. Those six sites plus 8-27 sample from the NURE sampling program were used to establish the background values. The variation in number of total sites reflects the difference in the number of elements that were determined at each NURE site. The locations of the background sites are shown in figure 6; medians for these background values are shown in table 2 .

Comparison between the analytical methods used for the October 2000 samples and the NURE samples was made. The NURE samples were originally analyzed using 
neutron activation methods. Twenty-five NURE samples were re-analyzed using the "total" digestion and ICP-AES methods. The results were compared statistically (t-test) for five metals, $\mathrm{As}, \mathrm{Cd}, \mathrm{Cu}, \mathrm{Pb}$, and $\mathrm{Zn}$. As and $\mathrm{Cd}$ values were not similar in the comparison of the two analytical methods, whereas, $\mathrm{Cu}, \mathrm{Pb}$, and $\mathrm{Zn}$ were similar.

Based on the results of the comparison, $\mathrm{Cu}, \mathrm{Pb}$ and $\mathrm{Zn}$ values from both data sets were used to estimate regional background values. Only re-analyzed NURE samples or samples from the October 2000 program were used in estimating background for As and Cd.

Table 2. Median background values of streambed sediments in the upper Prickly Pear Creek watershed. All values are in ppm. Partial-digestion values from October 2000 sampling program only. Total digestion values are from NURE and October 2000 programs.

\begin{tabular}{|l|c|c|c|c|}
\hline element & $\begin{array}{c}\text { Partial- } \\
\text { digestion } \\
\text { value }\end{array}$ & $\begin{array}{c}\text { Number of } \\
\text { samples }\end{array}$ & $\begin{array}{c}\text { Total } \\
\text { digestion } \\
\text { value }\end{array}$ & $\begin{array}{c}\text { Number of } \\
\text { samples }\end{array}$ \\
\hline $\mathrm{As}$ & 6.6 & 6 & 14 & 15 \\
\hline $\mathrm{Cd}$ & 1 & 6 & 4 & 16 \\
\hline $\mathrm{Cu}$ & 15 & 6 & 42 & 33 \\
\hline $\mathrm{Pb}$ & 12 & 6 & 25 & 30 \\
\hline $\mathrm{Zn}$ & 80 & 6 & 96 & 15 \\
\hline
\end{tabular}

\section{STREAMBED SEDIMENT METAL CHEMISTRY AND BIOLOGICAL SCREENING LEVELS}

The effect of streambed sediments on the ecosystem is complex, and it is difficult to assess their relationship on water chemistry. Streambed sediment chemistry is most directly related to the accumulation of metals by benthic fauna, which represent a food source for many fresh water fish. Sediment influence on water chemistry is more difficult to understand. The silicate and oxide mineral grains that make up most of the bed sediments release small amounts of metals over a long time span during weathering. Thus, high concentrations of those elements in silicate and oxide grains will likely not have a great effect on water chemistry. However, easily leachable metals found in oxyhydroxide grain coatings can have a marked effect on water chemistry and benthic fauna health. Large releases of metals into water may be induced by changes in water chemistry or flow conditions. Benthic fauna in direct contact with streambed sediment are also probably most affected by the easily leachable metals in oxy-hydroxide coatings because of their high solubility and the ease with which the coatings can be physically released during streambed sediment transport.

Screening-level concentrations of metals in streambed sediments are poorly understood. No standard has yet been adopted by any major environmental agency. 
Table 3 summarizes three different standards. The screening-level (SLC) is defined as the highest level of concentration of a metal in streambed sediment that can be tolerated by $95 \%$ of the benthic fauna (Jones and others, 1997). The acute effects threshold (AET) is the concentration of a metal in streambed sediment where statistically significant affects always occur in benthic fauna. The consensus-based screening-level concentration (CBSLC) uses an approach where the protective concentrations of metals are determined by a consensus of multiple methodologies (MacDonald and others, 2000). The value of the consensus-based approach is enhanced because multiple methodologies lead to similar conclusions, thereby validating the results. The CBSLC thresholds are used for comparison with the streambed sediment concentrations in the upper Prickly Pear Creek watershed in the following discussion. The populations of $\mathrm{As}, \mathrm{Cd}, \mathrm{Cu}, \mathrm{Pb}, \mathrm{Zn}$ concentrations in stream bed sediments in the Prickly Pear Creek watershed based on the October 2000 sampling program are summarized in figure 7. Metals in both the partialdigestion and total digestions are represented. The CBSLC and regional background concentration is also shown for each metal.

Figure 6. Locations of background streambed sediment sites, upper Prickly Pear Creek watershed.

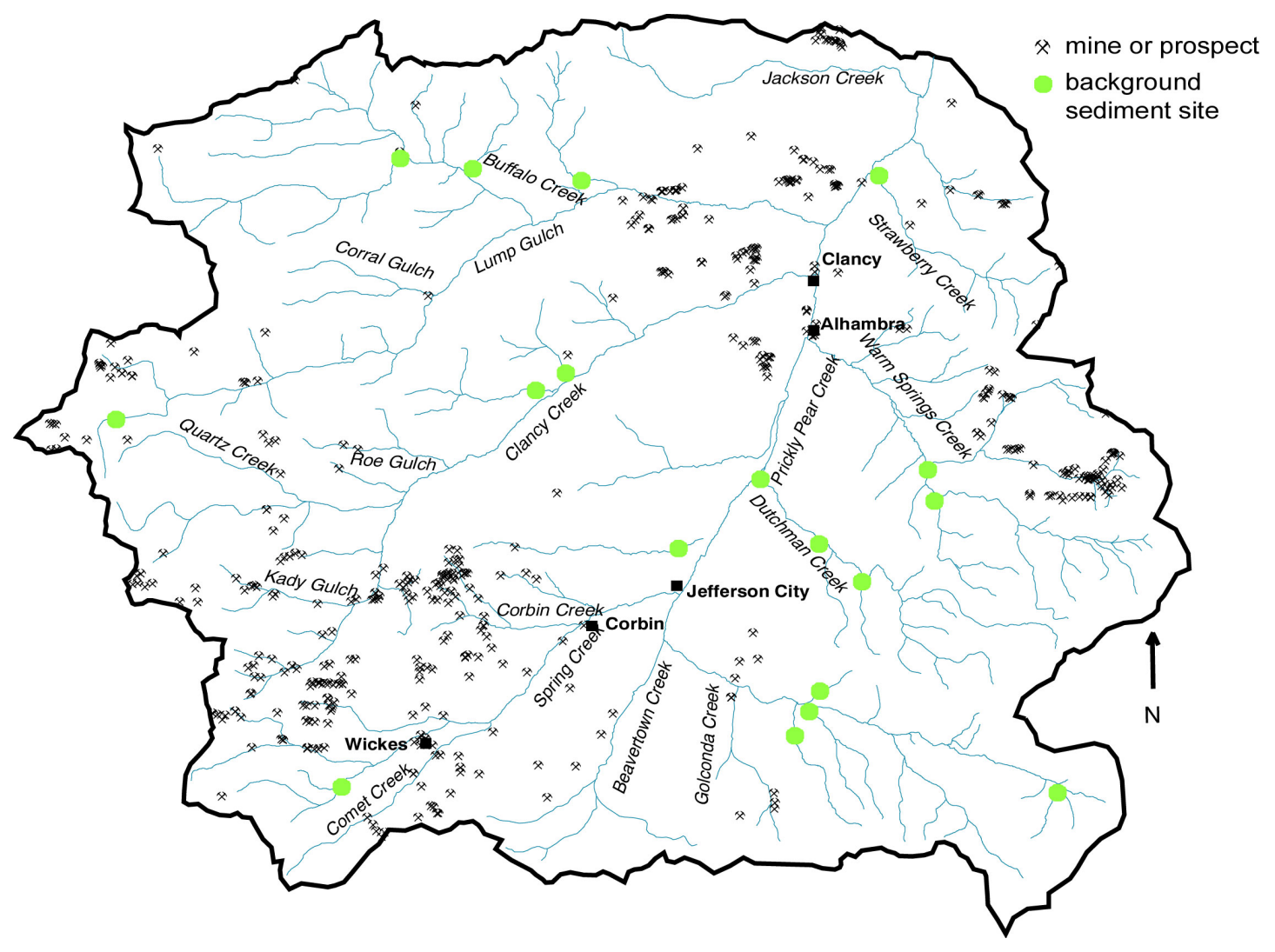


Table 3. Summary of provisional streambed sediment screening levels. Concentrations in ppm.

\begin{tabular}{|c|c|c|c|}
\hline element & $\begin{array}{c}\text { SLC range } \\
\text { (Jones and others, } \\
1997)\end{array}$ & $\begin{array}{c}\text { AET range } \\
\text { (Jones and } \\
\text { others, 1997) }\end{array}$ & $\begin{array}{c}\text { CBSLC } \\
\text { (Macdonald and } \\
\text { others, 2000 }\end{array}$ \\
\hline Arsenic & $7-12$ & $33-57$ & 33 \\
\hline Cadmium & $0.6-1.0$ & $10-12$ & 4.98 \\
\hline Copper & $16-34$ & $78-110$ & 149 \\
\hline Lead & $30-47$ & $250-400$ & 128 \\
\hline Zinc & $120-160$ & $820-1500$ & 459 \\
\hline
\end{tabular}

In the summary below, measured metal concentrations are examined in two ways. The concentrations are expressed in terms of enrichment or depletions relative to the regional background; this represents the sediment site in terms of metal levels relative to non-mineralized bedrock. The metal concentrations are also expressed in terms of the CBSLC level, which relates to the metal concentrations in benthic fauna and fishery health.

Partial-digestion (easily leachable) median values for As and $\mathrm{Cd}$ are $4 \mathrm{x}$ greater than regional background (fig. 7), $\mathrm{Cu}$ is $2 \mathrm{x}, \mathrm{Pb}$ is $9 \mathrm{x}$, and $\mathrm{Zn}$ is $7 \mathrm{x}$ greater than regional background. Enrichments relative to median values of the total-digestion analyses are somewhat lower for all elements. Total $\mathrm{As}$ is $3 \mathrm{x}, \mathrm{Cd}$ is $2 \mathrm{x}, \mathrm{Cu}$ is $1.5 \mathrm{x}$, and $\mathrm{Pb}$ and $\mathrm{Zn}$ are $5 \mathrm{x}$ enriched relative to regional background.

Leachable median values of $\mathrm{As}, \mathrm{Cd}$, and $\mathrm{Pb}$ are at the CBSLC level and $\mathrm{Zn}$ median value is $30 \%$ greater than the CBSLC, whereas $\mathrm{Cu}$ is $25 \%$ of the CBSLC. In other words, $50 \%$ of the sample sites ( 25 sample sites) are at or exceed the As, Cd, and $\mathrm{Pb}$ CBSLC, and more than $50 \%$ of the sites exceed the CBSLC for $\mathrm{Zn}$. For totaldigestion analyses, median values of As and Zn exceed the CBSLC by $50 \%$, median values of $\mathrm{Cd}$ by $100 \%$, and median values of $\mathrm{Cu}$ by $30 \%$. The median total $\mathrm{Pb}$ value is at approximately the same level as the CBSLC. For As and $\mathrm{Zn}$, median total value exceeds the CBSLC at $50 \%$ of the sample sites. Total Cd values at more than $50 \%$ of the sample sites exceed the CBSLC. Median Pb values are at the CBSLC at 50\% of the sample sites.

\section{RIBBON MAPS}

Preliminary interpretation of the metal distribution in streambed sediments was aided by plotting maps that show the metal values at the samples site. This concentration is carried headward along the stream segment until it is replaced by the value at another site on the segment, or the head of the stream segment is encountered. Thus, a stream segment can be characterized in terms of a metal concentration at a single site, which should approximate an integrated value for the stream above it. 
Figure 7. Population summary of base metal concentrations in the upper Prickly Pear Creek watershed. Based on fifty streambed sediment samples taken during October 2000. CBSLC is the consensus-based screening level concentration (MacDonald and others, 2000)
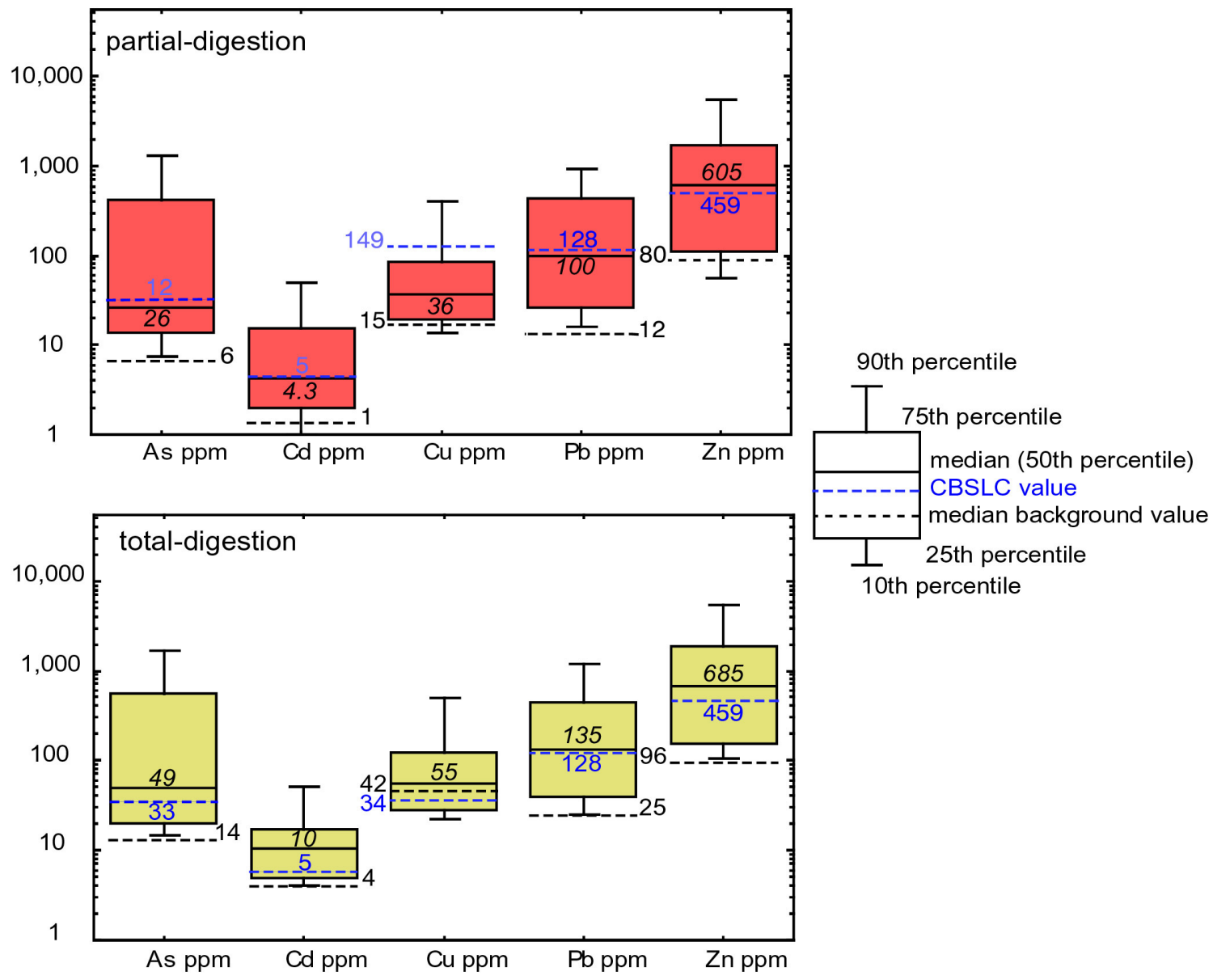

Figures 8 through 12 show the distribution of partial-digestion values for $\mathrm{As}, \mathrm{Cd}$, $\mathrm{Cu}, \mathrm{Pb}$, and $\mathrm{Zn}$. The value of each element at a site is normalized to the regional background value, which places the metal concentrations in a regional context. The CBSLC value for each element is shown in terms of concentration and its multiple of the regional background illustrates which drainage segments are above the guideline levels for biological effects. Values from the partial-digestion are shown in the following figures because they relate more directly to heavy metal effects on biota and water chemistry. Diagrams constructed using total-digestion values (not shown) show features similar to those for the partial-digestion values. 
Figure 8. Arsenic concentrations (partial-digestion) in upper Prickly Pear Creek watershed stream segments normalized to regional background.

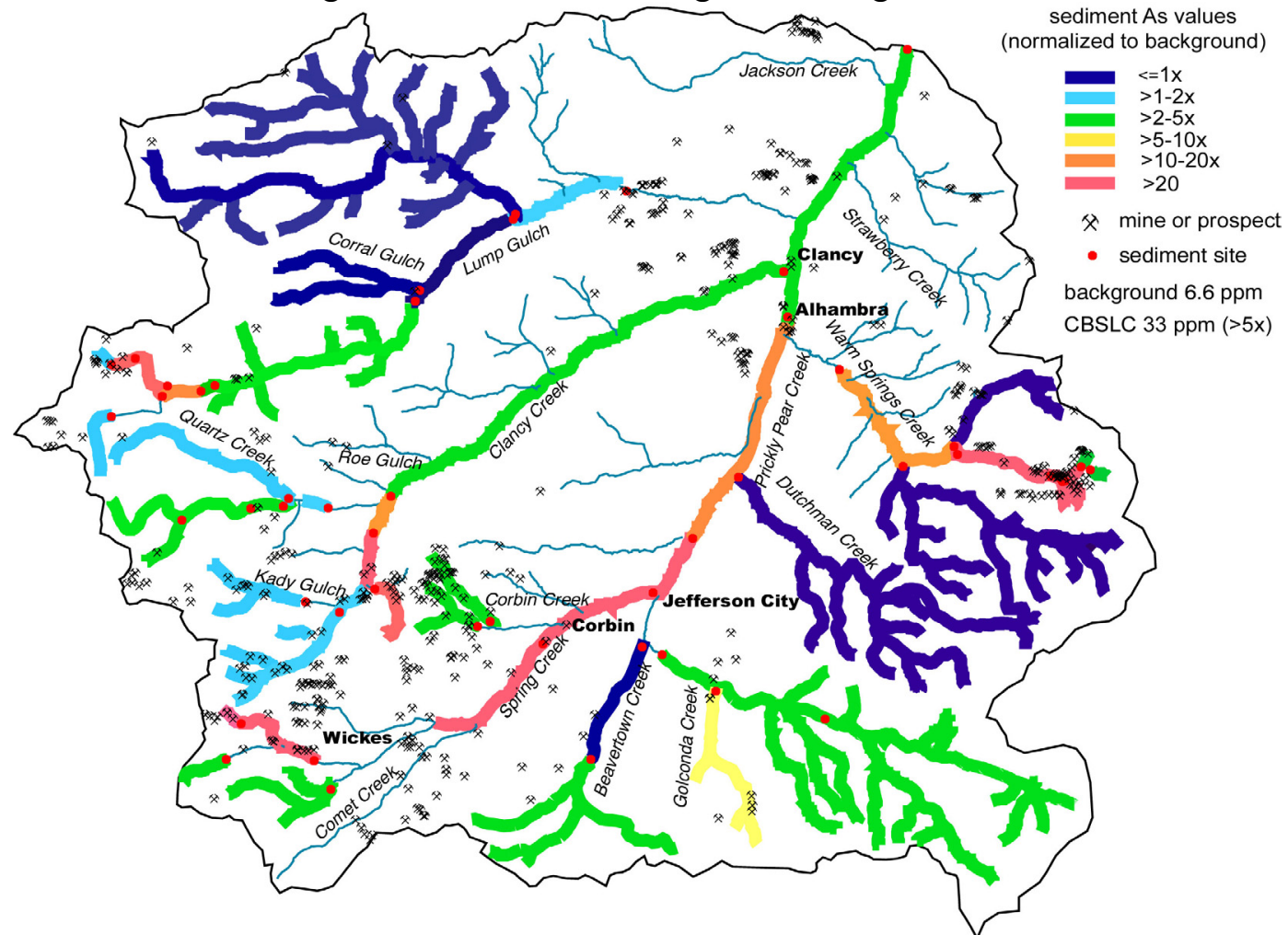

Figure 9. Cadmium concentrations (partial-digestion) in upper Prickly Pear Creek watershed stream segments normalized to regional background.

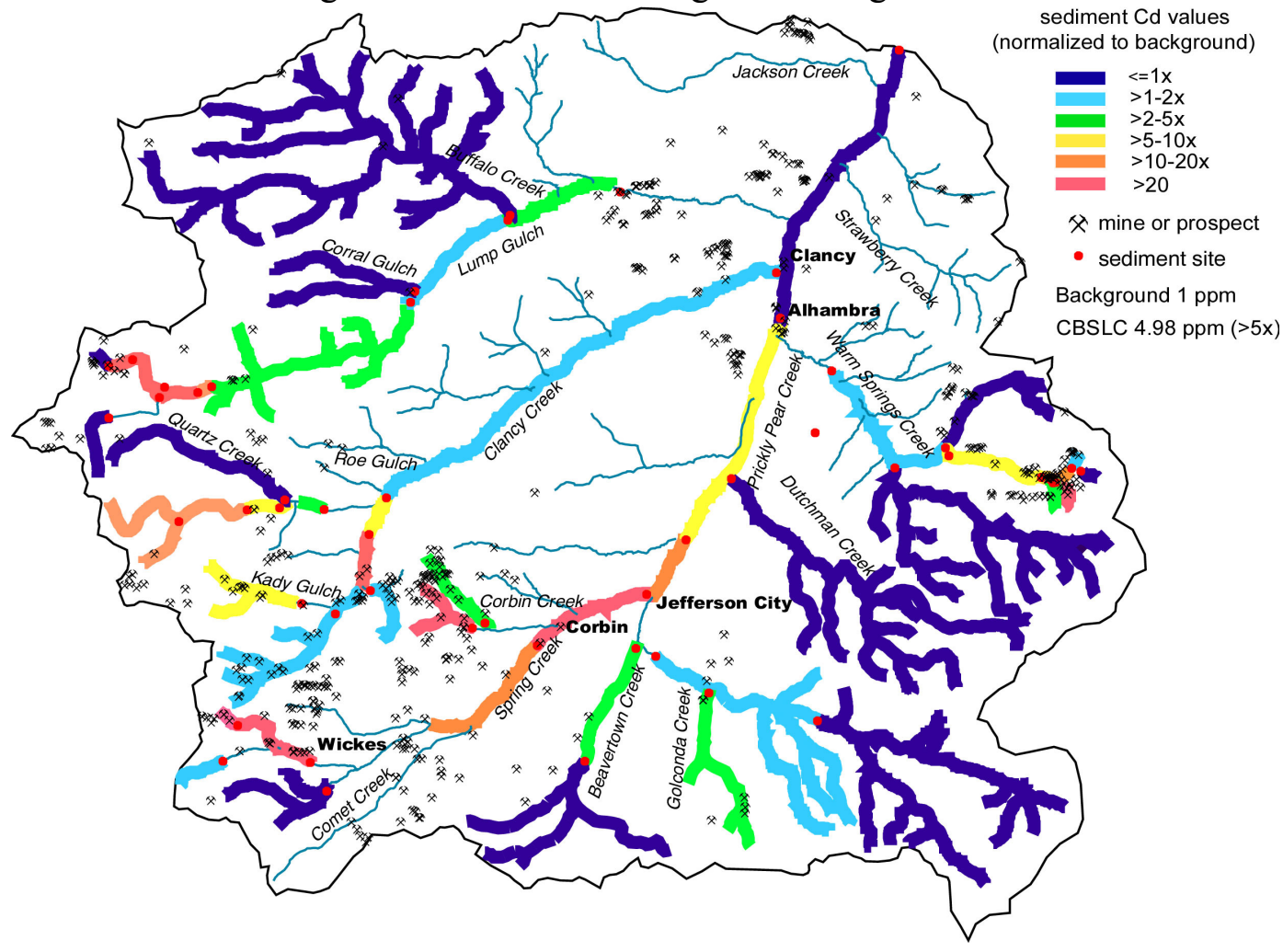


Figure 10. Copper concentrations (partial-digestion) in upper Prickly Pear Creek watershed stream segments normalized to regional background.

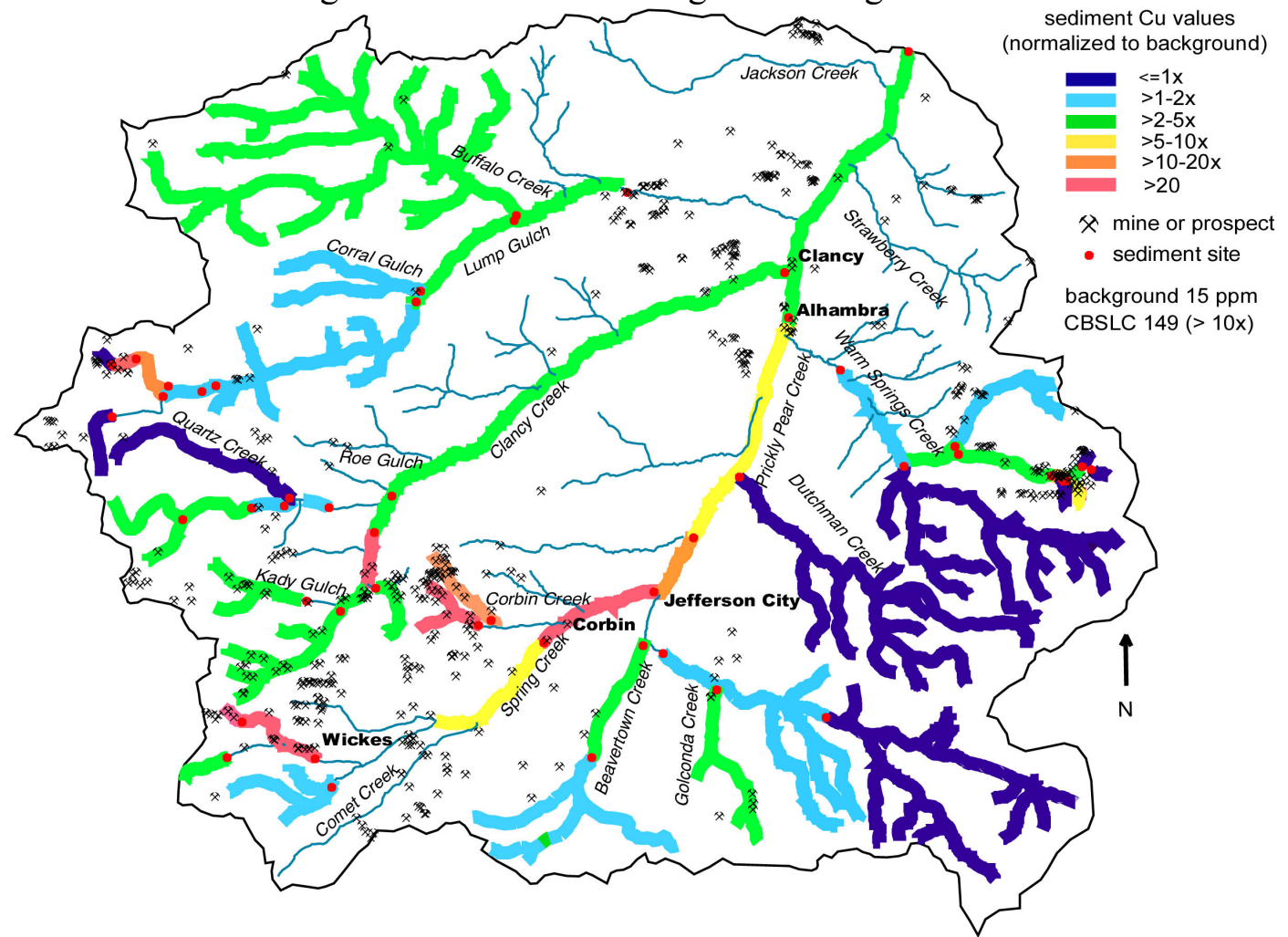

Figure 11. Lead concentrations (partial-digestion) in upper Prickly Pear Creek watershed stream segments normalized to regional background.

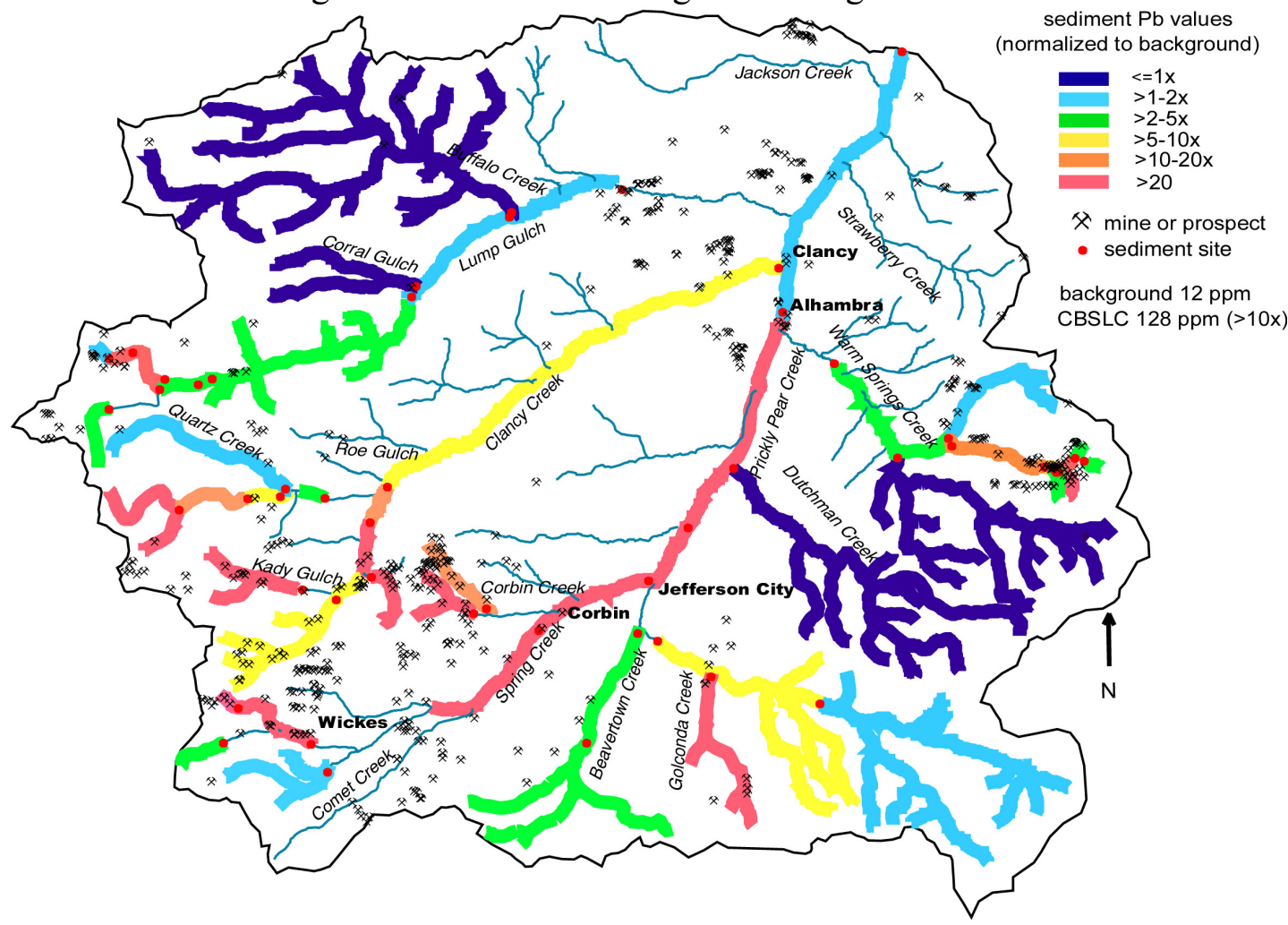


Figure 12. Zinc concentrations (partial-digestion) in upper Prickly Pear Creek watershed stream segments normalized to regional background.

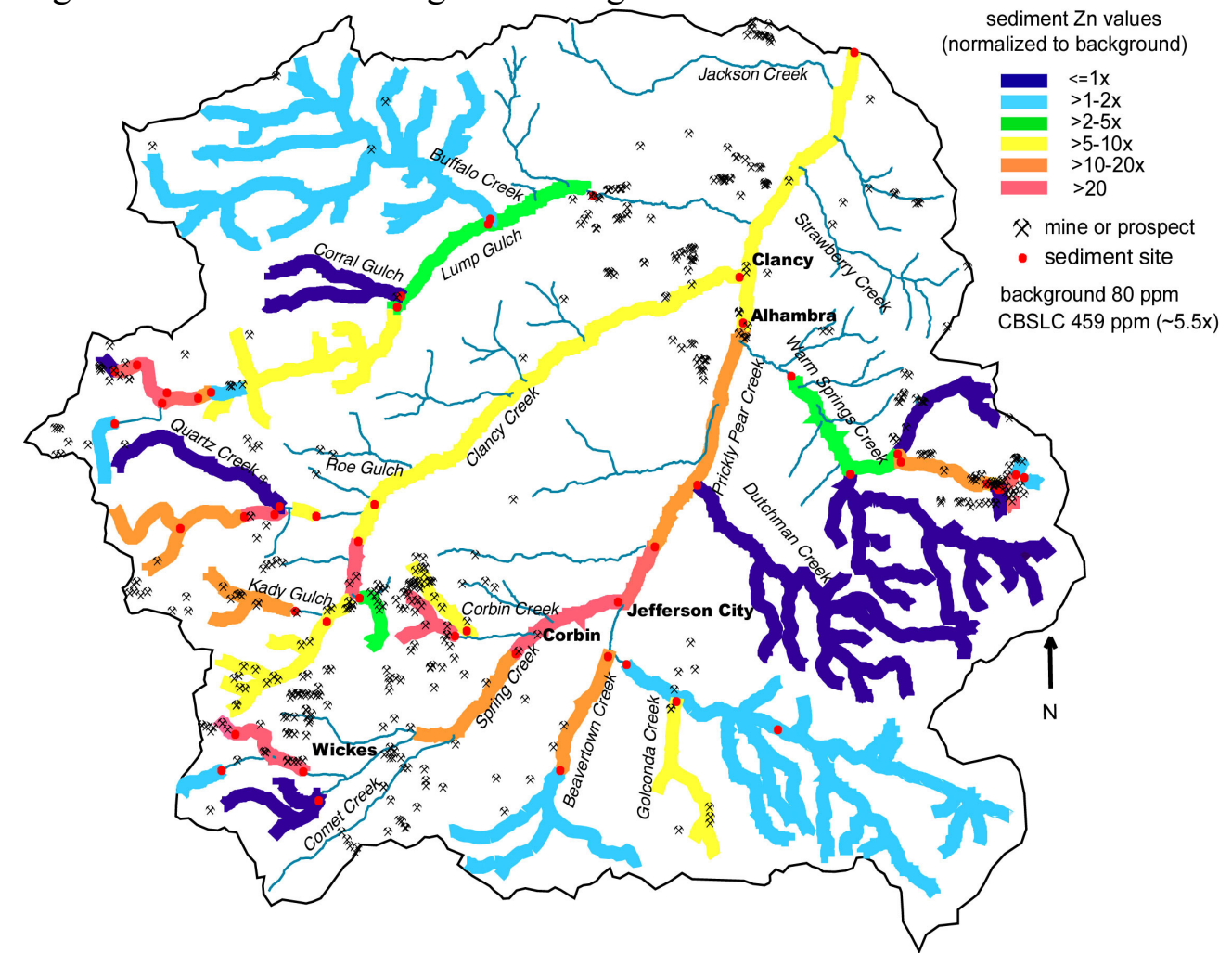

Streambed sediments in upper Lump Gulch show extreme enrichments relative to background in $\mathrm{As}, \mathrm{Cd}, \mathrm{Pb}$, and $\mathrm{Zn}$ from the Frohner and Nellie Grant mines to the outlets of Frohner Meadows, whereas $\mathrm{Cu}$ is moderately enriched (figs. 8-12). Below the meadows, $\mathrm{As}$ and $\mathrm{Pb}$ decrease to moderate levels at site L-5, whereas $\mathrm{Cd}$ and $\mathrm{Zn}$ are moderately enriched down to the lowest segment of Lump Gulch sampled.

In the south fork of Quartz Creek, streambed sediments are highly enriched in $\mathrm{Cd}$ and $\mathrm{Zn}$ with moderate enrichments of $\mathrm{As}$, and $\mathrm{Pb}$. The source of the metals is not known.

In Kady Gulch, $\mathrm{Pb}$ and $\mathrm{Zn}$ are moderately enriched. Downstream in upper Clancy Creek, near the Gregory mine and mill site, $\mathrm{As}$ and $\mathrm{Pb}$ are highly enriched in the unnamed southeastern fork below the Gregory mine, whereas downstream of the mill site, just above the junction with Quartz Creek, all metals are highly enriched. Downstream, enrichments in $\mathrm{As}, \mathrm{Cu}, \mathrm{Pb}$, and $\mathrm{Zn}$ at moderate levels are seen to site $\mathrm{C}-6$ near the junction of Clancy Creek and Prickly Pear Creek.

Warm Springs Creek is highly enriched in $\mathrm{As}, \mathrm{Cd}, \mathrm{Pb}$, and $\mathrm{Zn}$ in the area of mining at the headwaters of its central fork. Arsenic levels are highly enriched to sample site WS-7. The lower part of Warm Springs was not sampled. However, the high levels of As enrichment likely continues downstream to Prickly Pear Creek. High $\mathrm{Pb}$ and $\mathrm{Zn}$ enrichments continue from the mine area to the first major stream junction, below which they are moderately enriched. Cadmium and $\mathrm{Cu}$ only show significant enrichment in the area of the mines.

Golconda Creek is moderately enriched in $\mathrm{As}, \mathrm{Cd}, \mathrm{Cu}$, and $\mathrm{Zn}$. Lead is highly enriched. Contribution of $\mathrm{As}, \mathrm{Cd}, \mathrm{Cu}$, and $\mathrm{Pb}$ from Golconda Creek to upper Prickly 
Pear Creek may raise the metal levels in Prickly Pear Creek to slightly to moderately enriched below their junction.

In Beavertown Creek, $\mathrm{Zn}$ is highly enriched and $\mathrm{Cd}$ and $\mathrm{Cu}$ moderately enriched in the lower reach, whereas As is moderately enriched in the upper reach. Lead is moderately enriched throughout Beavertown Creek. High $\mathrm{Cu}$ values (24x background) in the NURE total analyses are present in Stagecoach and Copper Gulches, the two southwestern tributaries of upper Beavertown Creek. Partial-digestion data are not available for these sites, so they are not shown in figure 9.

Spring Creek drains a large area that is highly mineralized and extensively mined. Much of the drainage basin is underlain by highly altered bedrock and, as a result, many tributaries and most of its main stem are highly contaminated with metals. The only exceptions are the uppermost segments of the main stem. Comet Creek was not sampled during October 2000 but NURE total analyses show near-regional background levels. Other segments in the middle portion of the main stem were not sampled because either access to sites was not available or the sites lacked appropriate sampling media due to disturbed drainages and cultural effects. The unnamed drainage north of Wickes that drains the Mt. Washington mine shows highly anomalous concentrations of $\mathrm{As}, \mathrm{Cd}, \mathrm{Pb}$ and $\mathrm{Zn}$ in NURE total analyses. These results are not shown in Figs. 8-12 because samples from these sites have not been analyzed with the partial-digestion method.

Prickly Pear Creek below Jefferson City is highly enriched in As, $\mathrm{Pb}$ and $\mathrm{Zn}$ downstream to Alhambra. $\mathrm{Cd}$ and $\mathrm{Cu}$ are moderately enriched through this stream segment. Much of the enrichment appears to be related to sediments derived from Spring Creek. However, Beavertown Creek may contribute to $\mathrm{Cu}$ and $\mathrm{Zn}$ enrichment. Some As and perhaps Zn may be contributed to Prickly Pear Creek by Warm Springs Creek near Alhambra. Moderate levels of As, $\mathrm{Cu}$, and $\mathrm{Zn}$ enrichment persist below Alhambra to PP5, the most downstream sample site in the upper Prickly Pear Creek watershed.

The results of the partial-digestion determinations relative to the CBSLC are summarized in Figure 13. Stream segments that contain metal levels at or greater than the CBSLC are indicated. The metals exceeding the screening level are noted for each segment. 
Figure 13. Upper Prickly Pear Creek watershed stream segments that exceed CBSLC. Elements that exceed the screening level are noted for each stream segment.

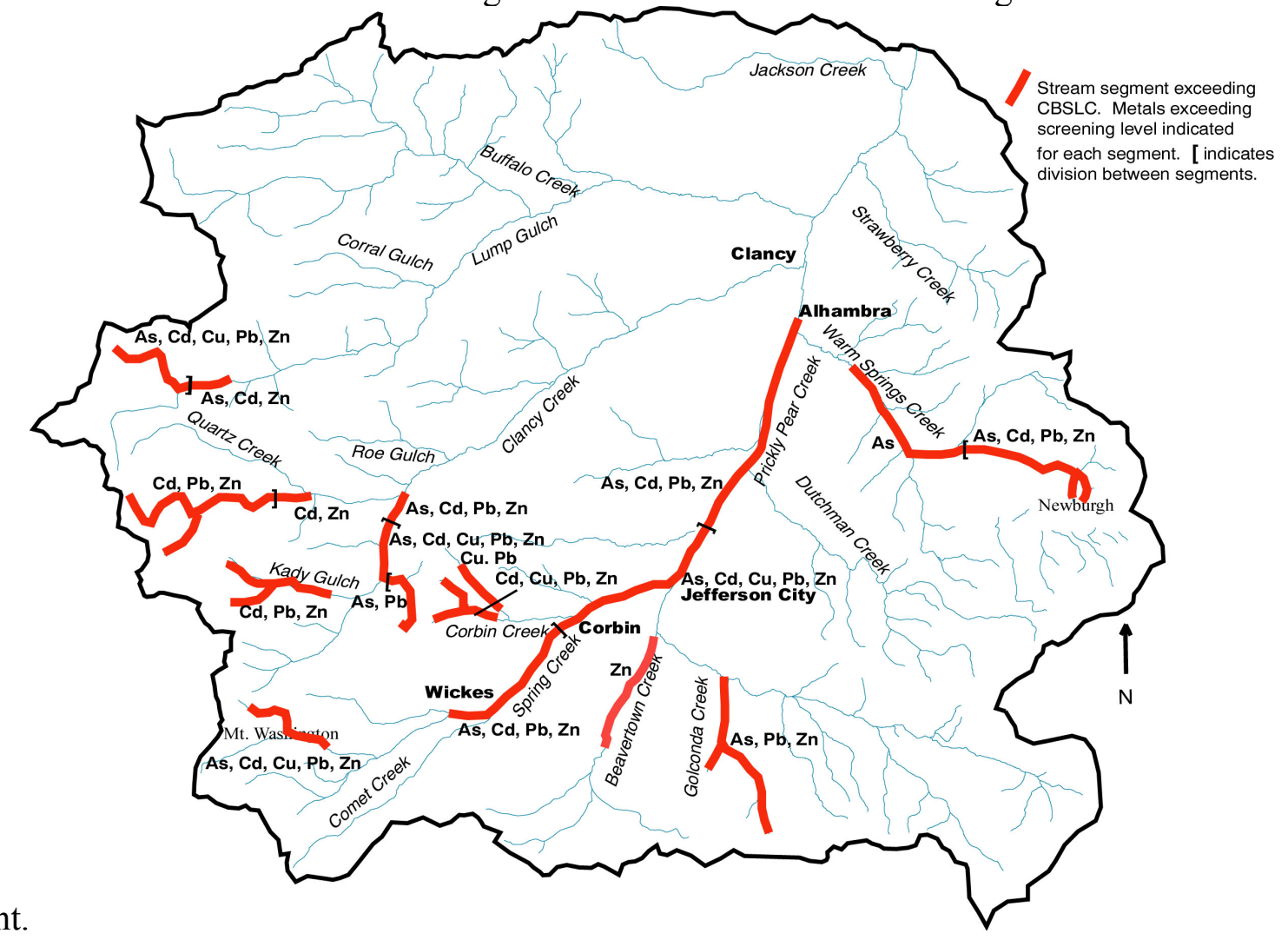

\section{RESULTS OF THE RECONNAISSANCE MERCURY IN WATER SURVEY}

Concentrations of mercury in both the filtered and unfiltered water samples are all at or below the analytical detection limit of $0.005 \mathrm{ppb}$. At samples sites S-1a (upper Spring Creek), S-4 (Spring Creek, above Jefferson City), and B-1 (lower Beavertown Creek), mercury concentrations in unfiltered samples were $0.005 \mu \mathrm{g} / \mathrm{l}$ (fig. 1). In upper Lump Gulch at the outlet to Frohner Meadows (site L-3b), the filtered sample contained $0.006 \mu \mathrm{g} / 1$ whereas the unfiltered sample was below the detection limit. The unfiltered sample should have given a minimum concentration similar to that of the filtered sample. This effect is caused by increased analytical uncertainty near the detection limit.

None of these concentrations in water approaches the $2.4 \mu \mathrm{g} / 1$ maximum stream water concentration or the $0.012 \mu \mathrm{g} / 1$ chronic effects level recommended by the U.S. Environmental Protection Agency (U.S. Environmental Protection Agency, 1992) and therefore is not considered to represent hazardous mercury concentrations. 


\title{
BIOLOGY DATA FOR STREAMS IN THE UPPER PRICKLY PEAR CREEK WATERSHED, MONTANA
}

\author{
By Aïda M. Farag and Bradley G. Mueller
}

\section{INTRODUCTION}

This section presents biology data that were collected in the upper Prickly Pear Creek watershed during October 2000. Data presented in this section include provisional measurements of metal residues in aquatic vegetation, biofilm (aufwuchs) benthic macroinvertebrates, and fish tissues. Specific results of quality assurance data are not yet available.

Site numbers for biology sampling were similar to the alpha-numeric system used for water quality and sediment sampling efforts. The alpha character denotes the first letter of the stream name and the numeric characters denote the downstream sequence, beginning at the most upstream site (fig. 1, table 1). Because multiple biology samples were collected from identical sites, additional numeric designations refer to the individual samples.

\section{BIOLOGY DATA}

Biology samples were collected from 14 sites (table 1). Aquatic vegetation was collected from 10 sites, biofilm was collected from 2 sites, benthic macroinvertebrates were collected from 13 sites, and fish tissues were collected from 5 sites. As, $\mathrm{Cu}, \mathrm{Cd}, \mathrm{Pb}$, and $\mathrm{Zn}$ were measured in all samples and reported as $\mu \mathrm{g} / \mathrm{g}$ dry weight (Appendix 10). Note: The biology data are presented as uncensored; therefore, some negative numbers appear for As. All of the biology data reported are provisional and the data in Appendix 10 should be viewed as preliminary.

\section{Methods}

Sampling methods were similar to those described by Farag et al. (1998). Rocks along the shore were removed from the water and their surface was scraped gently with acid-washed plastic utensils. The aquatic vegetation or biofilm was placed directly in acid-washed plastic vials. For benthos, an area of approximately $6 \mathrm{~m}^{2}$ was overturned upstream of a 3-mm mesh net. Benthos were removed with plastic or stainless steel forceps and placed in acid-washed vials. The invertebrates were rinsed with site water to remove debris, but they were not allowed time to depurate. Without depuration, the metal concentrations in the invertebrates represent the "dose" of metals received by fish. Fish were collected by electrofishing, fish were pithed and lengths and weights were recorded. Individual fish were placed in plastic bags for whole fish analyses of metals. Fillet, gills, livers, and pyloric caeca were removed from additional fish and each tissue was placed in an acid-washed plastic vial. In the laboratory, fillet, gills, livers, and pyloric caeca from approximately three fish were combined for a composite sample of each tissue. A duplicate sample was measured for every 20 samples (data not reported). All samples were measured with atomic absorption spectroscopy with graphite furnace or flame.

The tissues were dried at $58^{\circ} \mathrm{C}$ for 48 hours and digested with $30 \%$ nitric acid at $76^{\circ} \mathrm{C}$ for 48 hours. Quality control was monitored for all chemical analyses. Instrument calibration was verified by analyzing certified calibration solutions during each 
instrumental run. These external reference standards were generally within $80 \%$ to $120 \%$ of the nominal concentrations. All of the sample spikes for tissues were within $80 \%$ to $120 \%$ recovery. Preparation blanks were prepared to detect potential contamination during the digestion procedure. These preparation blanks generally measured below the detection limit.

\section{REFERENCES CITED}

Aamodt, P.L., 1978, Uranium hydrogeochemical and stream sediment pilot study of the Boulder batholith, Montana: GJBX-56 (78), U.S. Department of Energy, Grand Junction, Colorado, $118 \mathrm{p}$.

APHA,1995, Standard methods, $19^{\text {th }}$ ed., p. 2-36, method 2340 C (hardness of water)

APHA 1995, Standard methods, $19^{\text {th }}$ ed., p. 2-26, method 2320 B (alkalinity of water)

APHA 1995, Standard methods, $19^{\text {th }}$ ed., p. 3-68, method 3500-Fe D (total and soluble iron)

Becraft, G.E., Pinckney, D.M., and Rosenblum, S., 1963, Geology and mineral deposits of the Jefferson City Quadrangle, Jefferson and Lewis and Clark Counties, Montana: U.S. Geological Survey Professional Paper 428, 101 p.

Briggs, P.H., 1996, Forty elements by inductively coupled-plasma atomic emission spectrometry, in Arbogast, B.F., ed., Analytical methods manual for the Mineral Resources Program, U.S. Geological Survey Open-File Report 96-525, p. 77-94.

Broxton, W.W., 1980, Uranium hydrogeochemical and stream sediment reconnaissance data release for the Butte NTMS quadrangle, Montana, including concentrations of forty-two additional elements, GJBX-129 (80), U.S. Department of Energy, Grand Junction, Colorado, $207 \mathrm{p}$.

Chao, T.T., 1984, Use of partial dissolution techniques in geochemical exploration: Journal of Geochemical Exploration, v. 20, p. 101-135.

Crock, J.G., Lichte, F.E., and Briggs, 1983, Determination of elements in National Bureau of Standards geologic reference materials SRM 278 obsidian and SRM 688 basalt by inductively coupled plasma-atomic emission spectroscopy: Geostandards Newsletter, v.7, p. 335-340.

Church, S.E., Mosier, E.L., and Motooka, J.M., 1987, Mineralogical basis for the interpretation of multielement (ICP-AES), oxalic acid, and aqua-regia partial digestions of stream sediments for reconnaissance exploration geochemistry: Journal of Geochemical Exploration, v. 29, p. 207-233.

Church, S.E., Holmes, C.E., Briggs, P.H., Vaughn, R.B., Cathcart, James and Marot, Margaret, 1993, Geochemical and lead-isotope data from stream and lake sediments, and cores from the upper Arkansas River drainage: Effects of mining at Leadville Colorado on heavy-metal concentrations in the Arkansas River: U.S. Geological Survey Open-File Report 93-534, $61 \mathrm{p}$.

Church, S.E., Kimball, B.A., Fey, D.L., Ferderer, D.A., Yager, T.J., and Vaughn, R.B., 1997, Source, transport, and partitioning of metals between water, colloids, and bed sediments of the Animas River, Colorado: U.S. Geological Survey Open-File Report 97-151, $135 \mathrm{p}$

David Stiller and Assoc., OEA Research, 1983, Prickly Pear Creek abandoned mine lands study: Helena, Mont., prepared for Montana Department of State Lands, 90 p. 
Edwards, T.K., and Glysson, G.D., 1999, Field methods for measurement of fluvial sediment: U.S. Geological Survey Techniques of Water-Resources Investigations , book 3, chapter C2, 89 p.

Faires, L.M., 1993, Methods of analysis by the U.S. Geological Survey National Water Quality Laboratory-Determination of metals in water by inductively coupled plasma-mass spectrometry: U.S. Geological Survey Open-File Report 92-634, $28 \mathrm{p}$.

Farag, A.M., D.F. Woodward, J.N. Goldstein, W. Brumbaugh, and J.S. Meyer, 1998, Concentrations of metals associated with mining waste in sediments, biofilm, benthic macroinvertebrates, and fish from the Coeur d'Alene River Basin, Idaho: Archives of Environmental Contamination and Toxicology 34, p. 119-127.

Fey, D.L., and Church, S.E., 1998, Analytical results for 42 fluvial tailings cores and 7 stream-sediment samples from High Ore Creek, northern Jefferson County, Montana: U. S. Geological Survey Open-File Report 98-215, 49 p.

Fey, D.L., Unruh, D.M., and Church, S.E., 1999a, Chemical data and lead isotopic compositions in stream-sediment samples from the Boulder River watershed, Jefferson County, Montana: U. S. Geological Survey Open-File Report 99-575, $147 \mathrm{p}$

Fey, D.L., Church, S.E., and Finney, C.J., 1999b, Analytical results for 35 mine-waste tailings cores and six bed-sediment samples, and an estimate of the volume of contaminated material at Buckeye Meadow on upper Basin Creek, northern Jefferson County, Montana: U.S. Geological Survey Open-File Report 99-537, 59 p.

Fey, D.L., Church, S.E., and Finney, C.J., 2000, Analytical results for Bullion Mine and Crystal Mine waste samples and bed sediments from a small tributary to Jack Creek and from Uncle Sam Gulch, Boulder River watershed, Montana: U.S. Geological Survey Open-File Report 00-031, 63 p.

Fishman, M.J., 1993, Methods of analysis by the U.S. Geological Survey National Water Quality Laboratory-Determination of inorganic and organic constituents in water and fluvial sediments: U.S. Geological Survey Open-File Report 93-125, $217 \mathrm{p}$.

Fishman, M.J., and Friedman, L.C., 1989, Methods for determination of inorganic substances in water and fluvial sediments: U.S. Geological Survey Techniques of Water-Resources Investigations, book 5, chap. A6, $181 \mathrm{p}$.

Friedman, L.C., and Erdmann, D.E., 1982, Quality assurance practices for the chemical and biological analyses of water and fluvial sediments: U.S. Geological Survey Techniques of Water-Resources Investigations, book 5, chap. A1, 545 p.

Garbarino, J.R., 1999, Methods of analysis by the U.S. Geological Survey National Water Quality Laboratory-Determination of dissolved arsenic, boron, lithium, selenium, strontium, thallium, and vanadium using inductively coupled plasmamass spectrometry: U.S. Geological Survey Open-File Report 99-093, 31 p.

Garbarino, J.R., and Struzeski, T.M., 1998, Methods of analysis by the U.S. Geological Survey National Water Quality Laboratory-Determination of elements in wholewater digests using inductively coupled plasma-optical emission spectrometry and inductively coupled plasma-mass spectrometry: U.S. Geological Survey OpenFile Report 98-165, 101 p. 
Grotbo, M.F., and Stiller, D.M., 1984, Ground-water contamination in abandoned mine lands near Corbin, Montana: Montana Bureau of Mines and Geology Special Publication, v. 91, p. 25.

Guy, H.P., 1969, Laboratory theory and methods for sediment analysis: U.S. Geological Survey Techniques of Water-Resources Investigations, book 5, chap. C1, 58 p.

Hageman, P.L., 2001, Mercury in water by flow injection-cold vapor-atomic fluorescence spectrometry: U.S. Geological Survey Open-File report 2001-xxx xx p (in review)

Harper, Archie, 1999, Clancy-Unionville vegetation/travel management project affected environment and effects analysis for fisheries: Helena, Mont., U.S. Forest Service, $15 \mathrm{p}$.

Hoffman, G.L., Fishman, M.J., and Garbarino, J.R., 1996, Methods of analysis by the U.S. Geological Survey National Water Quality Laboratory-In bottle acid digestion of whole-water samples: U.S. Geological Survey Open-File Report 96-225, $28 \mathrm{p}$.

Horowitz, A.J., Demas, C.R., Fitzgerald, K.K., Miller, T.L., and Rickert, D.A., 1994, U.S. Geological Survey protocol for the collection and processing of surfacewater samples for the subsequent determination of inorganic constituents in filtered water: U.S. Geological Survey Open-File Report 94-539, 57 p.

Jones, B.E., 1987, Quality control manual of the U.S. Geological Survey's National Water-Quality Laboratory: U.S. Geological Survey Open-File Report 87-457, $17 \mathrm{p}$.

Jones, D.S., Suter, G.W.II, and Hull, R.N., 1997, Toxicology benchmarks for screening contaminants of potential conern for effects on sediment-associated biota: 1997 revision: Department of Energy Report ES/ER/TM-95/R4, 30 p.

Jones, S.R., and Garbarino, J.R., 1999, Methods of analysis by the U.S. Geological Survey National Water Quality Laboratory-Determination of arsenic and selenium in water and sediment by graphite furnace-atomic adsorption spectrometry: U.S. Geological Survey Open-File Report 98-639, 39 p.

Knapton, J.R., 1985, Field guidelines for collection, treatment, and analysis of water samples, Montana District: U.S. Geological Survey Open-File Report 85-409, $86 \mathrm{p}$.

Knapton, J.R., and Nimick, D.A., 1991, Quality assurance for water-quality activities of the U.S. Geological Survey in Montana: U.S. Geological Survey Open-File Report 91-216, $41 \mathrm{p}$.

Lambing, J.H., and Dodge, K.A., 1993, Quality assurance for laboratory analysis of suspended-sediment samples by the U.S. Geological Survey in Montana: U.S. Geological Survey Open-File Report 93-131, 34 p.

MacDonald, D.D., Ingersoll, C.G., and Berger, T.A., 2000, Development and evaluation of consensus-based sediment quality guidelines for freshwater ecosystems: Archives of Contamination and Toxicology 14, p. 20-31

Metesh, J.J., Lonn, J.D., Marvin, R.K., Hargrave, Phyllis, and Madison, J.P., 1993, Abandoned-inactive mines, Helena National Forest, Volume I--Upper Missouri River drainage: Montana Bureau of Mines and Geology Open-File Report 352, [variously paged]. 
[Montana] Department of Health and Environmental Sciences, 1981, Prickly Pear Creek, a report on manís debilitating impacts for use by the Prickly Pear Task Force:

Helena, Mont., Water Quality Bureau Report WQB No. 81-2 [variously paged].

Nimick, D.A., and Cleasby, T.E., 1999, Water-quality data for streams in the Boulder River watershed, Jefferson County, Montana: U.S. Geological Survey Open-File Report 00-99, 70 p.

Olympus Environmental Science and Engineering, Inc., 1998, Surface water quality investigation of the Middle Fork Warm Springs site: Helena, Mont., prepared for Montana Department of Environmental Quality, Mine Waste Cleanup Bureau, [variously paged].

Olympus Technical Services, Inc., 2000, Voluntary cleanup plan, upper Corbin area of the Corbin Flats Tailings Facility, Jefferson County, Montana: Helena, Mont.; submitted to Montana Department of Environmental Quality, Remediation Division, Hazardous Waste Site Cleanup Bureau; submitted by Montana Tunnels Mining, Inc., Jefferson City, Montana, [variously paged].

Patton, C.J., and Truitt, E.P., 1992, Methods of analysis by the U.S. Geological Survey National Water Quality LaboratoryóDetermination of total phosphorous by a Kjeldahl digestion method and an automated colorimetric finish that includes dialysis: U.S. Geological Survey Open-File Report 92-146, 39 p.

Pritt, J.W., and Raese, J.W., eds., 1995, Quality assurance quality/control manualóNational Water Quality Laboratory: U.S. Geological Survey Open-File Report 95-443, 35 p.

Rantz, S.E., and others, 1982, Measurement and computation of streamflow: U.S. Geological Survey Water-Supply Paper 2175, v. 2, Computation of discharge, p. 285-631.

Roby, R.N., Ackerman, F.B., Fulkerson, F.B., and Crowley, F.A., 1960, Mines and mineral deposits (except fuels) Jefferson County, Montana: Montana Bureau of Mines and Geology, Bulletin 16, 122 p.

Streamworks, 1984, Prickly Pear Creek, a stream corridor management plan, Jefferson and Lewis and Clark Counties, Montana: Helena, Mont., prepared for the Jefferson and Lewis and Clark Conservation Districts, [variously paged].

Smedes, H.W, 1966, Geology and igneous petrology of the northern Elkhorn Mountains, Jefferson and Broadwater Counties, Montana: U.S. Geological Survey Professional Paper 510, 116p.

Tysdale, R.G., Ludington, S. and McCafferty, A.E., 1996, Mineral and energy resource assessment of the Helena National Forest, west-central Montana: U.S. Geological Survey Open-file Report 96-683-A.

U.S. Environmental Protection Agency, 1992, Water quality standards; establishment of numeric criteria for priority toxic pollutants; states, compliance; final rule: Federal Register, 40 CFR Part 131, v. 57, no. 246, p. 60847-60916.

Ward, J.R., and Harr, C.A., eds., 1990, Methods for collection and processing of surface- water and bed-material samples for physical and chemical analyses: U.S. Geological Survey Open-File Report 90-140, 71 p. 
Wilson, S. A., Briggs, P.H., Mee, J.S., and Siems, D.F., 1994, Determinations of thirtytwo major and trace elements in three NIST soil SRMs using ICP-AES and WDXRF: Geostandards Newsletter, v. 18, p. 85-89 
Appendix 1. Physical properties and concentrations of selected major ions and trace elements in water samples collected from streams in the upper Prickly Pear Creek watershed, Montana, 2000.

[Samples collected by the U.S. Geological Survey. ANC, acid-neutralizing capacity determined on unfiltered samples, formerly referred to as alkalinity. Abbreviations: $\mathrm{ft}^{3} / \mathrm{s}$, cubic feet per second; ${ }^{0} \mathrm{C}$, degrees Celsius; $\mu \mathrm{g} / \mathrm{L}$, micrograms per liter; $\mu \mathrm{S} / \mathrm{cm}$, microsiemens per centimeter at $25^{\circ} \mathrm{C} ; \mathrm{mg} / \mathrm{L}$, milligrams per liter; mm, millimeters. Symbols: <, less than minimum reporting level; -- no data; $\mathrm{E}$,

\begin{tabular}{|c|c|c|c|c|c|c|c|c|c|c|c|c|}
\hline $\begin{array}{c}\text { Site } \\
\text { number }\end{array}$ & Date & Time & $\begin{array}{c}\text { Discharge } \\
\left(\mathrm{ft}^{3} / \mathrm{s}\right)\end{array}$ & $\begin{array}{l}\text { Sediment, } \\
\text { suspended } \\
\text { (mg/L) }\end{array}$ & $\begin{array}{c}\text { Sediment, } \\
\text { suspended, } \\
\text { diameter (percent } \\
\text { finer than } 0.062 \\
\mathrm{~mm} \text { ) }\end{array}$ & $\begin{array}{c}\text { Specific } \\
\text { conductance, } \\
\text { field } \\
(\mu \mathrm{S} / \mathrm{cm})\end{array}$ & $\begin{array}{c}\mathrm{pH}, \\
\text { field } \\
\text { (standard } \\
\text { units) }\end{array}$ & $\begin{array}{c}\text { Temperature, } \\
\text { water }\left({ }^{\circ} \mathrm{C}\right)\end{array}$ & $\begin{array}{c}\text { Hardnes } \\
\mathrm{s}(\mathrm{mg} / \mathrm{L} \\
\text { as } \\
\left.\mathrm{CaCO}_{3}\right)\end{array}$ & $\begin{array}{l}\text { Calcium, } \\
\text { dissolved } \\
\text { (mg/L as } \\
\text { Ca) }\end{array}$ & $\begin{array}{l}\text { Magnesium, } \\
\text { dissolved } \\
\text { (mg/L as Mg) }\end{array}$ & $\begin{array}{c}\text { ANC, lab } \\
\left(\mathrm{mg}^{\prime} \mathrm{L} \text { as }\right. \\
\left.\mathrm{CaCO}_{3}\right)\end{array}$ \\
\hline B-1 & $10-16-00$ & 1540 & 0.48 & 6 & 72 & 476 & 7.9 & 8.0 & 190 & 56 & 13 & -- \\
\hline $\mathrm{C}-1$ & $10-17-00$ & 1330 & 0.08 & 1 & 78 & 148 & 7.9 & 2.0 & 62 & 20 & 3.0 & -- \\
\hline$C-2$ & $10-17-00$ & 1210 & 1.0 & 2 & 50 & 207 & 8.1 & -- & 91 & 28 & 5.2 & -- \\
\hline C-3 & $10-17-00$ & 1600 & 0.36 & 11 & 60 & 138 & 8.0 & 4.0 & 56 & 18 & 2.8 & -- \\
\hline C-4 & $10-17-00$ & 1445 & 0.10 & 1 & 70 & 248 & 7.9 & 7.6 & 110 & 33 & 6.4 & -- \\
\hline \multirow[t]{3}{*}{ C-5 } & $06-14-00$ & 1215 & 1.6 & 4 & 83 & 192 & 8.1 & 9.0 & 82 & 24 & 5.2 & -- \\
\hline & $06-16-00$ & 1400 & 4.2 & 8 & 62 & 162 & 8.6 & 9.5 & 66 & 20 & 4.1 & -- \\
\hline & $10-17-00$ & 1340 & 1.3 & 3 & 68 & 224 & 8.0 & 7.2 & 98 & 29 & 6.0 & 66 \\
\hline C-6 & $10-12-00$ & 1430 & 0.89 & 7 & 40 & 276 & 8.1 & 6.5 & 110 & 32 & 7.9 & -- \\
\hline D-1 & $10-16-00$ & 0945 & 1.4 & 2 & 54 & 112 & 8.0 & 3.5 & 44 & 13 & 2.7 & -- \\
\hline G-1 & $10-16-00$ & 1240 & 0.51 & 1 & 50 & 105 & 8.6 & 5.5 & 40 & 13 & 2.0 & -- \\
\hline \multirow[t]{2}{*}{ L-1 } & $06-16-00$ & 1230 & 2.2 & 1 & 78 & 43 & 7.7 & 5.5 & 18 & 5.9 & .85 & -- \\
\hline & $10-11-00$ & 1220 & 0.14 & 1 & 60 & 87 & 7.3 & 0.5 & 35 & 11 & 1.6 & -- \\
\hline \multirow[t]{2}{*}{ L-2 } & $06-16-00$ & 1045 & 0.16 & 2 & 62 & 61 & 8.1 & 4.0 & 24 & 8.0 & 1.1 & -- \\
\hline & $10-11-00$ & 1000 & 0.04 & 1 & 47 & 88 & 8.4 & 2.0 & 35 & 11 & 1.5 & -- \\
\hline \multirow[t]{2}{*}{ L-3a } & $06-16-00$ & 1415 & 0.62 & 1 & 67 & 119 & 7.2 & 10.0 & 41 & 13 & 2.0 & -- \\
\hline & $10-11-00$ & 1345 & 0.0003 & 14 & 97 & 483 & 6.3 & 1.5 & 210 & 67 & 9.2 & -- \\
\hline \multirow[t]{2}{*}{ L-3b } & $06-16-00$ & 1445 & 1.2 & 2 & 83 & 138 & 7.2 & 12.0 & 47 & 15 & 2.2 & -- \\
\hline & $10-11-00$ & 1630 & 0.11 & 1 & 80 & 398 & 6.0 & 2.0 & 150 & 49 & 6.1 & -- \\
\hline L-3c & $10-11-00$ & 1450 & 0.15 & 2 & 90 & 203 & 6.9 & 2.0 & 78 & 25 & 3.9 & -- \\
\hline \multirow[t]{2}{*}{ L-4 } & $06-16-00$ & 1545 & 1.8 & 7 & 59 & 89 & 7.7 & 12.0 & 34 & 10 & 1.9 & -- \\
\hline & $10-11-00$ & 1520 & 0.18 & 2 & 57 & 129 & 7.1 & 2.0 & 49 & 15 & 2.8 & -- \\
\hline
\end{tabular}




\begin{tabular}{|c|c|c|c|c|c|c|c|c|c|c|c|c|}
\hline $\begin{array}{c}\text { Site } \\
\text { number }\end{array}$ & Date & Time & $\begin{array}{l}\text { Discharge } \\
\left(\mathrm{ft}^{3} / \mathrm{s}\right)\end{array}$ & $\begin{array}{l}\text { Sediment, } \\
\text { suspended } \\
\text { (mg/L) }\end{array}$ & $\begin{array}{c}\text { Sediment, } \\
\text { suspended, } \\
\text { diameter (percent } \\
\text { finer than } 0.062 \\
\mathrm{~mm} \text { ) }\end{array}$ & $\begin{array}{c}\text { Specific } \\
\text { conductance, } \\
\text { field } \\
(\mu \mathrm{S} / \mathrm{cm})\end{array}$ & $\begin{array}{c}\mathrm{pH}, \\
\text { field } \\
\text { (standard } \\
\text { units) }\end{array}$ & $\begin{array}{c}\text { Temperature, } \\
\text { water }\left({ }^{\circ} \mathrm{C}\right)\end{array}$ & $\begin{array}{c}\text { Hardnes } \\
\text { s (mg/L } \\
\text { as } \\
\left.\mathrm{CaCO}_{3}\right)\end{array}$ & $\begin{array}{l}\text { Calcium, } \\
\text { dissolved } \\
(\mathrm{mg} / \mathrm{L} \text { as } \\
\mathrm{Ca})\end{array}$ & $\begin{array}{l}\text { Magnesium, } \\
\text { dissolved } \\
\text { (mg/L as Mg) }\end{array}$ & $\begin{array}{c}\text { ANC, lab } \\
(\mathrm{mg} / \mathrm{L} \text { as } \\
\left.\mathrm{CaCO}_{3}\right)\end{array}$ \\
\hline \multirow[t]{3}{*}{$L-5$} & $06-12-00$ & 1415 & 0.93 & 1 & 60 & 127 & 8.1 & 13.0 & 68 & 20 & 4.2 & -- \\
\hline & $06-16-00$ & 1715 & 3.9 & 2 & 62 & 114 & 7.7 & 11.5 & 42 & 12 & 2.7 & -- \\
\hline & $10-17-00$ & 0900 & 1.2 & 1 & 88 & 146 & 8.1 & 3.0 & 59 & 17 & 3.8 & 47 \\
\hline \multirow[t]{2}{*}{ L-6 } & $06-16-00$ & 1800 & 1.2 & 28 & 76 & 125 & 7.7 & 10.0 & 45 & 13 & 3.1 & -- \\
\hline & $10-17-00$ & 0940 & 0.35 & 2 & 47 & 331 & 7.2 & 3.0 & 120 & 36 & 8.1 & -- \\
\hline \multirow[t]{2}{*}{ L-7 } & $06-16-00$ & 1020 & 7.3 & 5 & 84 & 117 & 7.8 & 9.0 & 44 & 13 & 2.9 & -- \\
\hline & $10-17-00$ & 1120 & 1.1 & 4 & 94 & 184 & 7.6 & 4.5 & 71 & 21 & 4.5 & -- \\
\hline \multirow[t]{2}{*}{ L-8 } & $06-16-00$ & 1120 & 4.5 & 15 & 79 & 226 & 7.8 & 9.0 & 78 & 23 & 5.3 & -- \\
\hline & $10-17-00$ & 1045 & 0.67 & 1 & 75 & 442 & 7.3 & 4.0 & 170 & 52 & 11 & -- \\
\hline \multirow[t]{2}{*}{ L-9 } & $06-16-00$ & 1240 & 11 & 12 & 77 & 172 & 8.1 & 10.5 & 61 & 18 & 4.0 & -- \\
\hline & $10-17-00$ & 1230 & 2.4 & 2 & 71 & 281 & 7.8 & 5.0 & 110 & 32 & 6.9 & -- \\
\hline PP-1 & $10-16-00$ & 1100 & 3.5 & 1 & 64 & 89 & 7.9 & 4.0 & 37 & 12 & 1.8 & 37 \\
\hline PP-2 & $10-16-00$ & 1350 & 4.7 & 2 & 70 & 111 & 8.3 & 6.5 & 44 & 14 & 2.3 & -- \\
\hline \multirow[t]{3}{*}{ PP-3 } & $06-14-00$ & 1415 & 3.7 & 1 & 45 & 176 & 7.9 & 10.0 & 49 & 14 & 3.2 & -- \\
\hline & $06-16-00$ & 1640 & 8.9 & 6 & 43 & 176 & 7.8 & 10.5 & 67 & 20 & 4.2 & -- \\
\hline & $10-16-00$ & 1630 & 3.3 & 6 & 72 & 213 & 7.7 & 8.5 & 81 & 24 & 4.8 & 49 \\
\hline PP-4 & $10-12-00$ & 1330 & 11 & 6 & 64 & 282 & 8.1 & 8.0 & 85 & 25 & 5.5 & -- \\
\hline \multirow[t]{3}{*}{ PP-5 } & $06-12-00$ & 0920 & 16 & 4 & 98 & 269 & 8.3 & 11.5 & 91 & 26 & 6.3 & -- \\
\hline & $06-16-00$ & 1745 & 45 & 26 & 64 & 201 & 8.1 & 13.0 & 70 & 20 & 4.8 & -- \\
\hline & $10-19-00$ & 0945 & 17 & 5 & 73 & 282 & 8.1 & 8.0 & 97 & 28 & 6.4 & 81 \\
\hline$S-1$ & $10-18-00$ & 1040 & 0.02 & 3 & 65 & 133 & 8.1 & 8.5 & 56 & 17 & 3.6 & -- \\
\hline$S-1 a$ & $10-18-00$ & 1300 & 0.07 & 21 & 99 & 316 & 7.7 & 8.0 & 130 & 41 & 6.9 & -- \\
\hline S-3 & $10-19-00$ & 1100 & 2.4 & 18 & 40 & 603 & 7.8 & 8.0 & 270 & 85 & 14 & -- \\
\hline S-4 & $10-16-00$ & 1450 & 0.04 & 3 & 43 & 521 & 8.2 & 9.5 & 230 & 72 & 11 & -- \\
\hline WS-1 & $10-12-00$ & 1050 & 0.06 & 4 & 84 & 98 & 8.3 & 2.5 & 35 & 10 & 2.2 & -- \\
\hline WS-2 & $10-11-00$ & 1100 & 0.28 & 2 & 65 & 245 & 8.1 & 4.5 & 110 & 30 & 7.6 & -- \\
\hline
\end{tabular}




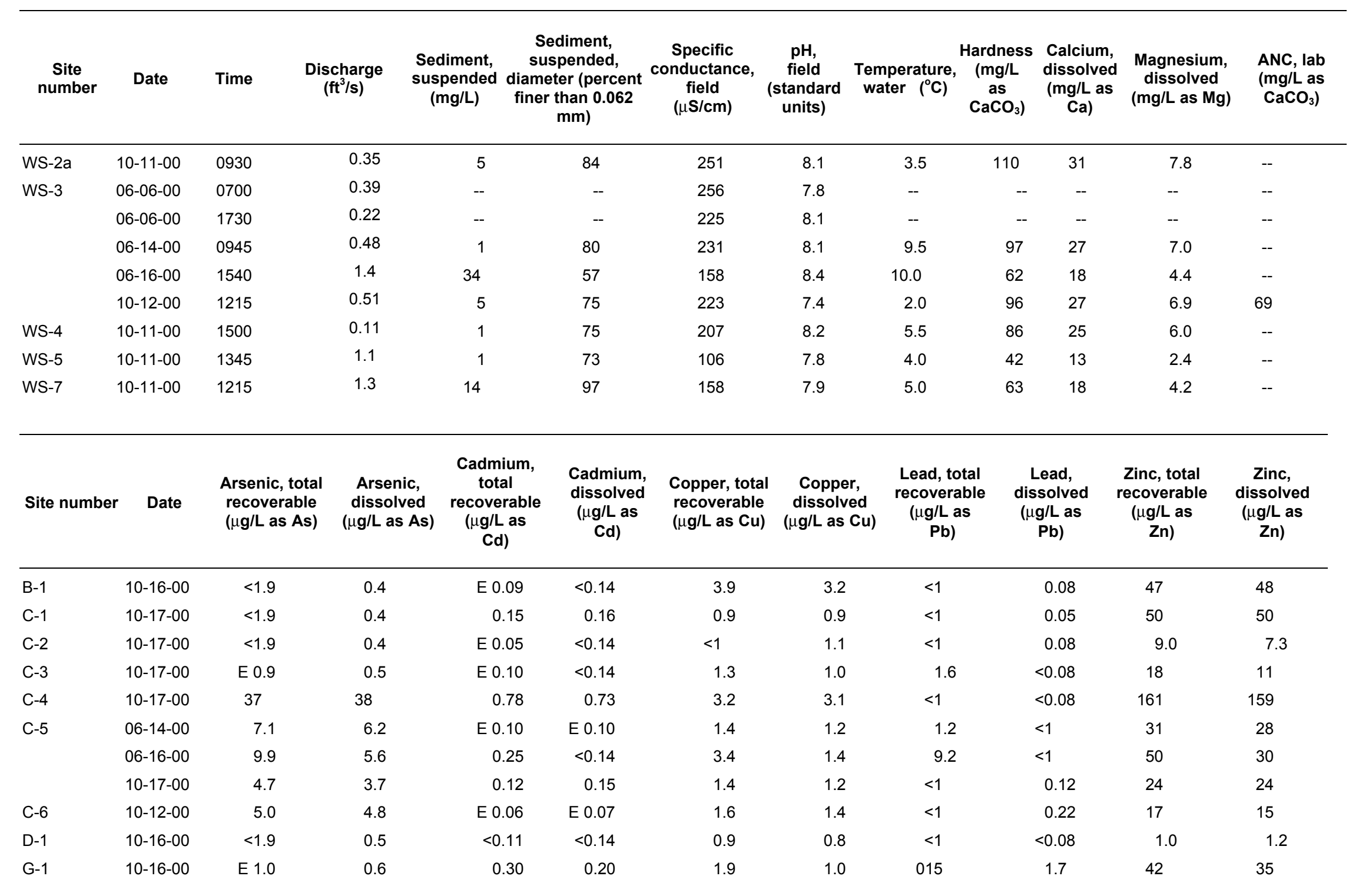




\begin{tabular}{|c|c|c|c|c|c|c|c|c|c|c|c|}
\hline Site number & Date & $\begin{array}{l}\text { Arsenic, total } \\
\text { recoverable } \\
\text { ( } \mu \mathrm{g} / \mathrm{L} \text { as As) }\end{array}$ & $\begin{array}{c}\text { Arsenic, } \\
\text { dissolved } \\
(\mu \mathrm{g} / \mathrm{L} \text { as As) }\end{array}$ & $\begin{array}{l}\text { Cadmium, } \\
\text { total } \\
\text { recoverable } \\
(\mu \mathrm{g} / \mathrm{L} \text { as } \\
\text { Cd })\end{array}$ & $\begin{array}{l}\text { Cadmium, } \\
\text { dissolved } \\
(\mu \mathrm{g} / \mathrm{L} \text { as } \\
\text { Cd })\end{array}$ & $\begin{array}{l}\text { Copper, total } \\
\text { recoverable } \\
\text { ( } \mu \mathrm{g} / \mathrm{L} \text { as } \mathrm{Cu} \text { ) }\end{array}$ & $\begin{array}{c}\text { Copper, } \\
\text { dissolved } \\
(\mu \mathrm{g} / \mathrm{L} \text { as } \mathrm{Cu})\end{array}$ & $\begin{array}{l}\text { Lead, total } \\
\text { recoverable } \\
(\mu \mathrm{g} / \mathrm{L} \text { as } \\
\mathrm{Pb})\end{array}$ & $\begin{array}{l}\text { Lead, } \\
\text { dissolved } \\
(\mu \mathrm{g} / \mathrm{L} \text { as } \\
\mathrm{Pb})\end{array}$ & $\begin{array}{l}\text { Zinc, total } \\
\text { recoverable } \\
(\mu \mathrm{g} / \mathrm{L} \text { as } \\
\mathrm{Zn})\end{array}$ & $\begin{array}{c}\text { Zinc, } \\
\text { dissolved } \\
(\mu \mathrm{g} / \mathrm{L} \text { as } \\
\mathrm{Zn})\end{array}$ \\
\hline \multirow[t]{2}{*}{ L-1 } & $06-16-00$ & E 1.7 & 1.4 & $<0.11$ & $<0.14$ & 2.1 & 2.5 & $<1$ & $<1$ & $<4.7$ & 5.6 \\
\hline & $10-11-00$ & $<1.9$ & 0.9 & $<0.11$ & $<0.14$ & $<1$ & 0.8 & $<1$ & $<0.08$ & 2.6 & 2.0 \\
\hline \multirow[t]{2}{*}{$\mathrm{L}-2$} & $06-16-00$ & E 1.8 & 1.4 & $<0.11$ & $<0.14$ & 1.6 & 1.7 & $<1$ & $<1$ & $<2.4$ & 1.4 \\
\hline & $10-11-00$ & $<1.9$ & 0.9 & $<0.11$ & $<0.14$ & $<1$ & 0.6 & $<1$ & $<0.08$ & 1.6 & $<1$ \\
\hline \multirow[t]{2}{*}{ L-3a } & $06-16-00$ & 6.3 & 5.3 & 6.3 & 6.9 & 7.4 & 8.2 & 2.1 & 1.3 & 1,450 & 1,570 \\
\hline & $10-11-00$ & 9.8 & 7.8 & 9.8 & 9.9 & 2.7 & 2.1 & $<1$ & $<0.08$ & 3,970 & 4,090 \\
\hline \multirow[t]{2}{*}{$L-3 b$} & $06-16-00$ & 15 & 9.7 & 13 & 14 & 11 & 11 & 8.3 & 3.7 & 2,650 & 2,750 \\
\hline & $10-11-00$ & 6.0 & 1.6 & 47 & 48 & 5.8 & 4.1 & 4.3 & 0.19 & 15,400 & 15,100 \\
\hline L-3c & $10-11-00$ & $<1.9$ & 0.5 & 3.4 & 3.0 & 1.2 & 1.0 & $<1$ & $<0.08$ & 1,580 & 1,560 \\
\hline \multirow[t]{2}{*}{ L-4 } & $06-16-00$ & 3.3 & 2.1 & 0.42 & 0.26 & 2.3 & 2.0 & $<1$ & $<1$ & 158 & 152 \\
\hline & $10-11-00$ & $<1.9$ & 0.9 & 0.16 & E 0.11 & 1.1 & 0.9 & $<1$ & $<0.08$ & 149 & 150 \\
\hline \multirow[t]{3}{*}{$L-5$} & $06-12-00$ & $<2.6$ & 1.7 & 0.29 & 0.31 & 2.3 & 2.2 & 1.0 & $<1$ & 166 & 163 \\
\hline & $06-16-00$ & E 1.8 & 2.6 & 0.13 & E 0.10 & 1.4 & $<1$ & $<1$ & $<1$ & 81 & $<1$ \\
\hline & $10-17-00$ & $<1.9$ & 0.50 & E 0.07 & $<0.14$ & $<1$ & 0.75 & $<1$ & $<0.08$ & 30 & 31 \\
\hline \multirow[t]{2}{*}{ L-6 } & $06-16-00$ & $<2.6$ & $<0.9$ & $<0.11$ & $<0.14$ & 5.0 & 3.1 & $<1$ & $<1$ & $<4.0$ & 1.5 \\
\hline & $10-17-00$ & $<1.9$ & 0.3 & $<0.11$ & $<0.14$ & 2.0 & 1.7 & $<1$ & $<0.08$ & 2.1 & 1.2 \\
\hline \multirow[t]{2}{*}{ L-7 } & $06-16-00$ & $<2.6$ & E 0.7 & E 0.08 & $<0.14$ & 2.1 & 1.7 & $<1$ & $<1$ & 55 & 41 \\
\hline & $10-17-00$ & $<1.9$ & 0.6 & $<0.11$ & $<0.14$ & 1.1 & 1.0 & $<1$ & $<0.08$ & 28 & 30 \\
\hline \multirow[t]{2}{*}{ L-8 } & 06-16-00 & $<2.6$ & E 0.5 & $<0.11$ & $<0.14$ & 7.6 & 4.3 & $<1$ & $<1$ & $<3.9$ & 1.3 \\
\hline & $10-17-00$ & $<1.9$ & 0.2 & $<0.11$ & $<0.14$ & 2.9 & 2.5 & $<1$ & $<0.08$ & 3.6 & 2.3 \\
\hline \multirow[t]{2}{*}{ L-9 } & $06-16-00$ & $<2.6$ & E 0.7 & E 0.07 & $<0.14$ & 4.6 & 2.5 & $<1$ & $<1$ & 37 & 18 \\
\hline & $10-17-00$ & $<1.9$ & 0.4 & $<0.11$ & $<0.14$ & 1.7 & 1.6 & $<1$ & $<0.08$ & 15 & 15 \\
\hline PP-1 & $10-16-00$ & $<1.9$ & 0.4 & $<0.11$ & $<0.14$ & 1.1 & 1.0 & $<1$ & $<0.08$ & 1.3 & 1.3 \\
\hline PP-2 & $10-16-00$ & $<1.9$ & 0.3 & E 0.08 & $<0.14$ & 0.9 & 0.8 & $<1$ & 0.10 & 5.9 & 5.3 \\
\hline \multirow[t]{2}{*}{ PP-3 } & $06-14-00$ & $<2.6$ & E 0.8 & E 0.07 & $<0.14$ & 1.2 & 1.3 & $<1$ & $<1$ & 48 & 50 \\
\hline & $06-16-00$ & E 2.1 & 1.8 & 0.35 & 0.36 & 3.1 & 2.5 & 2.4 & $<1$ & 192 & 183 \\
\hline
\end{tabular}




\begin{tabular}{|c|c|c|c|c|c|c|c|c|c|c|c|}
\hline Site number & Date & $\begin{array}{l}\text { Arsenic, total } \\
\text { recoverable } \\
\text { ( } \mu \mathrm{g} / \mathrm{L} \text { as As) }\end{array}$ & $\begin{array}{c}\text { Arsenic, } \\
\text { dissolved } \\
(\mu \mathrm{g} / \mathrm{L} \text { as As })\end{array}$ & $\begin{array}{l}\text { Cadmium, } \\
\text { total } \\
\text { recoverable } \\
(\mu \mathrm{g} / \mathrm{L} \text { as } \\
\text { Cd })\end{array}$ & $\begin{array}{c}\text { Cadmium, } \\
\text { dissolved } \\
(\mu \mathrm{g} / \mathrm{L} \text { as } \\
\text { Cd })\end{array}$ & $\begin{array}{l}\text { Copper, total } \\
\text { recoverable } \\
\text { ( } \mu \mathrm{g} / \mathrm{L} \text { as } \mathrm{Cu})\end{array}$ & $\begin{array}{c}\text { Copper, } \\
\text { dissolved } \\
(\mu \mathrm{g} / \mathrm{L} \text { as } \mathrm{Cu})\end{array}$ & $\begin{array}{l}\text { Lead, total } \\
\text { recoverable } \\
(\mu \mathrm{g} / \mathrm{L} \text { as } \\
\mathrm{Pb})\end{array}$ & $\begin{array}{l}\text { Lead, } \\
\text { dissolved } \\
(\mu \mathrm{g} / \mathrm{L} \text { as } \\
\mathrm{Pb})\end{array}$ & $\begin{array}{l}\text { Zinc, total } \\
\text { recoverable } \\
\text { (ug/L as } \\
\mathrm{Zn})\end{array}$ & $\begin{array}{c}\text { Zinc, } \\
\text { dissolved } \\
(\mu \mathrm{g} / \mathrm{L} \text { as } \\
\mathrm{Zn})\end{array}$ \\
\hline & $10-16-00$ & 2.2 & 1.8 & 0.42 & 0.33 & 3.2 & 2.2 & 5.4 & 0.14 & 171 & 173 \\
\hline PP-4 & $10-12-00$ & 7.0 & 5.9 & 0.19 & 0.19 & 3.1 & 2.3 & 3.1 & 0.43 & 72 & 68 \\
\hline \multirow[t]{3}{*}{ PP-5 } & $06-12-00$ & 5.5 & 4.7 & 0.20 & E 0.09 & 2.8 & 1.8 & 4.3 & $<1$ & 73 & 59 \\
\hline & $06-16-00$ & 10 & 5.0 & 0.39 & $<0.14$ & 6.6 & 2.3 & 18 & $<1$ & 91 & 31 \\
\hline & $10-19-00$ & 5.7 & 4.2 & 0.17 & $<0.14$ & 2.8 & 2.0 & 4.9 & 0.40 & 77 & 61 \\
\hline S-1 & $10-18-00$ & 6.0 & 5.1 & $<0.11$ & $<0.14$ & $<1$ & 0.4 & $<1$ & $<0.08$ & 1.6 & 1.2 \\
\hline S-1a & $10-18-00$ & 51 & 7.6 & 7.6 & 4.9 & 112 & 5.3 & 38 & E 0.07 & 1,131 & 898 \\
\hline S-3 & $10-19-00$ & 12 & 4.3 & 1.3 & 0.73 & 5.3 & 1.9 & 12 & E 0.07 & 81 & 68 \\
\hline S-4 & $10-16-00$ & 14 & 6.0 & 1.5 & 0.53 & 17 & 3.8 & 55 & 0.45 & 203 & 63 \\
\hline WS-1 & $10-12-00$ & 2.0 & 1.6 & 2.4 & 2.4 & 4.4 & 4.1 & 1.1 & .22 & 21 & 21 \\
\hline WS-2 & $10-11-00$ & 32 & 18 & 0.50 & 0.32 & 1.9 & 1.0 & 1.1 & E 0.06 & 175 & 170 \\
\hline WS-2a & $10-11-00$ & 53 & 35 & 0.49 & 0.45 & 2.5 & 1.7 & 4.6 & 0.09 & 178 & 181 \\
\hline \multirow[t]{5}{*}{ WS-3 } & $06-06-00$ & -- & 41 & -- & 0.41 & -- & 1.8 & -- & -- & -- & 141 \\
\hline & $06-06-00$ & -- & 46 & -- & 0.36 & -- & 1.9 & -- & -- & -- & 113 \\
\hline & $06-14-00$ & 42 & 39 & 0.43 & 0.41 & 1.9 & 1.7 & 2.1 & $<1$ & 126 & 129 \\
\hline & $06-16-00$ & 87 & 36 & 0.89 & 0.37 & 6.8 & 3.4 & 30 & $<1$ & 208 & 125 \\
\hline & $10-12-00$ & 53 & 37 & 0.37 & 0.33 & 2.6 & 1.2 & 5.1 & $<0.08$ & 145 & 120 \\
\hline WS-4 & $10-11-00$ & $<1.9$ & 1.0 & $<0.11$ & $<0.14$ & 1.2 & 1.1 & $<1$ & 0.22 & $<1$ & $<1$ \\
\hline WS-5 & $10-11-00$ & $<1.9$ & 0.5 & $<0.11$ & $<0.14$ & $<1$ & 0.4 & $<1$ & $<0.08$ & $<1$ & $<1$ \\
\hline WS-7 & $10-11-00$ & 9.3 & 8.3 & $<0.11$ & $<0.14$ & $<1$ & 0.8 & $<1$ & E 0.05 & 22 & 20 \\
\hline
\end{tabular}


Appendix 2. Concentrations of additional trace elements at periodic water-quality sites in the upper Prickly Pear Creek watershed, Montana, 2000

[Samples collected by the U.S. Geological Survey. Abbreviations: $\mu \mathrm{g} / \mathrm{L}$, micrograms per liter. Symbols: <, less than minimum reporting level; E, estimated]

\begin{tabular}{|c|c|c|c|c|c|c|c|}
\hline Site number & Date & Time & $\begin{array}{l}\text { Aluminum, } \\
\text { total } \\
\text { recoverable } \\
(\mu \mathrm{g} / \mathrm{L} \text { as } \\
\mathrm{Al})\end{array}$ & $\begin{array}{c}\text { Aluminum, } \\
\text { dissolved } \\
(\mu \mathrm{g} / \mathrm{L} \text { as } \\
\text { Al })\end{array}$ & $\begin{array}{l}\text { Antimony, } \\
\text { total } \\
\text { recoverable } \\
\text { ( } \mu \text { g/L as } \\
\text { Sb) }\end{array}$ & $\begin{array}{c}\text { Antimony, } \\
\text { dissolved }(\mu \mathrm{g} / \mathrm{L} \\
\text { as } \\
\text { Sb) }\end{array}$ & $\begin{array}{c}\text { Chromium, } \\
\text { total } \\
\text { recoverable } \\
(\mu \mathrm{g} / \mathrm{L} \text { as } \\
\mathrm{Cr})\end{array}$ \\
\hline C-5 & $10-17-00$ & 1340 & 16 & 1.1 & $<0.9$ & 0.14 & -- \\
\hline L-5 & $10-17-00$ & 0900 & 4.2 & $<1$ & $<0.9$ & 0.08 & -- \\
\hline PP-3 & $10-16-00$ & 1630 & 25 & $<1$ & $<0.9$ & 0.25 & E 0.6 \\
\hline PP-5 & $10-19-00$ & 0945 & 87 & 2.5 & $<0.9$ & 0.50 & E 0.7 \\
\hline WS-3 & $10-12-00$ & 1215 & 87 & 1.1 & $<0.9$ & 0.16 & E 0.5 \\
\hline Site number & Date & $\begin{array}{l}\text { Chromium, } \\
\text { dissolved }(\mu \mathrm{g} / \mathrm{L} \\
\text { as } \\
\text { Cr) }\end{array}$ & $\begin{array}{c}\text { Iron, } \\
\text { total } \\
\text { recoverable } \\
(\mu \mathrm{g} / \mathrm{L} \text { as } \\
\mathrm{Fe})\end{array}$ & $\begin{array}{l}\text { Iron, dissolved } \\
(\mu \mathrm{g} / \mathrm{L} \text { as } \\
\mathrm{Fe})\end{array}$ & $\begin{array}{l}\text { Manganese, } \\
\text { total } \\
\text { recoverable } \\
(\mu \mathrm{g} / \mathrm{L} \text { as } \mathrm{Mn})\end{array}$ & $\begin{array}{c}\text { Manganese, } \\
\text { dissolved }(\mu \mathrm{g} / \mathrm{L} \\
\text { as } \mathrm{Mn})\end{array}$ & $\begin{array}{c}\text { Mercury, total } \\
\text { recoverable } \\
(\mu \mathrm{g} / \mathrm{L} \text { as } \\
\mathrm{Hg})\end{array}$ \\
\hline C-5 & $10-17-00$ & $<0.8$ & 67 & 12 & 15 & 11 & $<00.14$ \\
\hline L-5 & $10-17-00$ & $<0.8$ & 107 & 23 & E 2.8 & 0.79 & $<0.14$ \\
\hline PP-3 & $10-16-00$ & $<0.8$ & 53 & $<10$ & 18 & 3.7 & $<0.14$ \\
\hline PP-5 & $10-19-00$ & E 0.4 & 288 & 50 & 68 & 34 & $<0.14$ \\
\hline WS-3 & $10-12-00$ & $<0.8$ & 450 & $<10$ & 26 & 3.9 & $<0.14$ \\
\hline Site number & Date & $\begin{array}{c}\text { Mercury, } \\
\text { dissolved } \\
(\mu \mathrm{g} / \mathrm{L} \text { as } \\
\mathrm{Hg})\end{array}$ & $\begin{array}{r}\mathrm{Ni} \\
\text { total } \mathrm{rec} \\
(\mu \mathrm{g}\end{array}$ & $\begin{array}{l}\text { :kel, } \\
\text { :overable } \\
\text { LL as } \\
\text { ii) }\end{array}$ & $\begin{array}{l}\text { dissolved tota } \\
\text { ig/L as } \\
\mathrm{Ni})\end{array}$ & $\begin{array}{l}\text { Silver, } \\
\text { tal recoverable Si } \\
(\mu \mathrm{g} / \mathrm{L} \text { as } \\
\mathrm{Ag})\end{array}$ & $\begin{array}{l}\text { ilver, dissolved } \\
\qquad \begin{array}{c}(\mu \mathrm{g} / \mathrm{L} \text { as } \\
\mathrm{Ag})\end{array}\end{array}$ \\
\hline C-5 & $10-17-00$ & $<0.23$ & & 1 & 0.27 & $<1$ & $<0.16$ \\
\hline L-5 & $10-17-00$ & $<0.23$ & & 1 & 0.21 & $<1$ & $<0.16$ \\
\hline PP-3 & $10-16-00$ & $<0.23$ & & 1 & 0.62 & $<1$ & $<0.16$ \\
\hline PP-5 & $10-19-00$ & $<0.23$ & & 1 & 0.39 & $<1$ & $<0.16$ \\
\hline WS-3 & $10-12-00$ & $<0.23$ & & 1 & 0.38 & $<1$ & $<0.16$ \\
\hline
\end{tabular}


Appendix 3. Water-quality data for field duplicates, upper Prickly Pear Creek watershed, Montana

[Samples collected by the U.S. Geological Survey. Abbreviations: ${ }^{0} \mathrm{C}$, degrees Celsius; lab, laboratory; $\mu \mathrm{g} / \mathrm{L}$, micrograms per liter; $\mu \mathrm{S} / \mathrm{cm}$, microsiemen per centimeter at $25^{\circ} \mathrm{C} ; \mathrm{mg} / \mathrm{L}$, milligrams per liter. Symbol: <, less than minimum reporting level]

\begin{tabular}{|c|c|c|c|c|c|c|c|c|}
\hline \multirow{2}{*}{$\begin{array}{c}\begin{array}{c}\text { Site } \\
\text { number }\end{array} \\
\text { C-4 }\end{array}$} & \multirow{2}{*}{$\begin{array}{c}\text { Date } \\
10-17-00\end{array}$} & \multirow{2}{*}{$\begin{array}{l}\text { Time } \\
1445\end{array}$} & \multicolumn{2}{|c|}{$\begin{array}{c}\text { Specific } \\
\text { conductance, } \\
\text { lab } \\
(\mu \mathrm{S} / \mathrm{cm})\end{array}$} & \multirow{2}{*}{$\begin{array}{c}\begin{array}{c}\text { pH, lab } \\
\text { (standard } \\
\text { units) }\end{array} \\
7.7\end{array}$} & $\begin{array}{l}\text { Hardness } \\
(\mathrm{mg} / \mathrm{L} \text { as } \\
\left.\mathrm{CaCO}_{3}\right)\end{array}$ & \multirow{2}{*}{$\begin{array}{l}\text { Calcium, } \\
\text { dissolved } \\
\text { (mg/L as } \\
\text { Ca) }\end{array}$} & \multirow{2}{*}{$\begin{array}{c}\text { Magnesium, } \\
\text { dissolved } \\
\text { (mg/L as } \\
\mathrm{Mg})\end{array}$} \\
\hline & & & 257 & & & 110 & & \\
\hline & $10-17-00$ & 1450 & 254 & & 7.3 & 110 & 32 & 6.3 \\
\hline \multirow[t]{2}{*}{ L-7 } & $10-17-00$ & 1120 & 185 & & 7.7 & 71 & 21 & 4.5 \\
\hline & $10-17-00$ & 1125 & 186 & & 7.7 & 70 & 21 & 4.5 \\
\hline \multirow[t]{2}{*}{ PP-4 } & $10-12-00$ & 1330 & 286 & & 7.7 & 85 & 25 & 5.5 \\
\hline & $10-12-00$ & 1335 & 286 & & 7.8 & 86 & 25 & 5.6 \\
\hline \multirow[t]{2}{*}{ WS-3 } & $06-14-00$ & 0945 & 234 & & 8.1 & 97 & 27 & 7.0 \\
\hline & $06-14-00$ & 0950 & 232 & & 7.9 & 98 & 27 & 7.1 \\
\hline $\begin{array}{c}\text { Site } \\
\text { number }\end{array}$ & Date & $\begin{array}{l}\text { Arsenic } \\
\text { recove } \\
(\mu \mathrm{g} / \mathrm{L} \text { a }\end{array}$ & $\begin{array}{l}\text { c, total } \\
\text { erable } \\
\text { as As) }\end{array}$ & $\begin{array}{c}\text { Arsenic, } \\
\text { dissolved } \\
(\mu \mathrm{g} / \mathrm{L} \text { as } \\
\text { As) }\end{array}$ & $\begin{array}{l}\text { Cadmium, total } \\
\text { recoverable } \\
(\mu \mathrm{g} / \mathrm{L} \text { as Cd })\end{array}$ & $\begin{array}{c}\text { Cadmium, } \\
\text { dissolved } \\
(\mu \mathrm{g} / \mathrm{L} \text { as Cd })\end{array}$ & $\begin{array}{l}\text { Copper, total } \\
\text { recoverable } \\
(\mu \mathrm{g} / \mathrm{L} \text { as } \mathrm{Cu})\end{array}$ & $\begin{array}{c}\text { Copper, } \\
\text { dissolved } \\
(\mu \mathrm{g} / \mathrm{L} \text { as } \\
\mathrm{Cu})\end{array}$ \\
\hline \multirow[t]{2}{*}{ C-4 } & $10-17-00$ & 37 & & 38 & 0.78 & 0.73 & 3.2 & 3.1 \\
\hline & $10-17-00$ & 37 & & 38 & 0.81 & 0.75 & 3.3 & 3.0 \\
\hline \multirow[t]{2}{*}{ L-7 } & $10-17-00$ & $<1.9$ & & 0.64 & $<0.11$ & $<0.14$ & 1.1 & 0.96 \\
\hline & $10-17-00$ & $<1.9$ & & 0.64 & $<0.11$ & $<0.14$ & $<1$ & 0.95 \\
\hline \multirow[t]{2}{*}{ PP-4 } & $10-12-00$ & 7.0 & & 5.9 & 0.19 & 0.19 & 3.1 & 2.3 \\
\hline & $10-12-00$ & 7.0 & & 6.1 & 0.14 & 0.21 & 3.1 & 2.3 \\
\hline \multirow[t]{2}{*}{ WS-3 } & $06-14-00$ & 42 & & 39 & 0.43 & 0.41 & 1.9 & 1.7 \\
\hline & $06-14-00$ & 43 & & 40 & 0.45 & 0.36 & 1.9 & 1.7 \\
\hline $\begin{array}{c}\text { Site } \\
\text { number }\end{array}$ & Date & $\begin{array}{l}\text { Lead, } \\
\text { recove } \\
\text { ( } \mu \mathrm{g} / \mathrm{L} \mathrm{a}\end{array}$ & $\begin{array}{l}\text { total } \\
\text { erable } \\
\text { as } \mathrm{Pb} \text { ) }\end{array}$ & $\begin{array}{l}\text { Lead, } \\
\text { dissolved } \\
(\mu \mathrm{g} / \mathrm{L} \text { as } \\
\mathrm{Pb})\end{array}$ & $\begin{array}{l}\text { Zinc, total } \\
\text { recoverable } \\
(\mu \mathrm{g} / \mathrm{L} \text { as } \mathrm{Zn})\end{array}$ & $\begin{array}{c}\text { Zinc, } \\
\text { dissolved } \\
(\mu \mathrm{g} / \mathrm{L} \text { as } \mathrm{Zn})\end{array}$ & & \\
\hline \multirow[t]{2}{*}{ C-4 } & $10-17-00$ & $<1$ & & $<0.08$ & 161 & 159 & & \\
\hline & $10-17-00$ & $<1$ & & 0.14 & 161 & 179 & & \\
\hline \multirow[t]{2}{*}{$\mathrm{L}-7$} & $10-17-00$ & $<1$ & & $<0.08$ & 28 & 30 & & \\
\hline & $10-17-00$ & $<1$ & & $<0.08$ & 28 & 34 & & \\
\hline \multirow[t]{2}{*}{ PP-4 } & $10-12-00$ & & 3.1 & 0.43 & 72 & 68 & & \\
\hline & $10-12-00$ & & 3.1 & 0.41 & 73 & 68 & & \\
\hline \multirow[t]{2}{*}{ WS-3 } & $06-14-00$ & & 2.1 & $<1$ & 126 & 129 & & \\
\hline & $06-14-00$ & & 2.0 & $<1$ & 126 & 132 & & \\
\hline
\end{tabular}


Appendix 4. Water-quality data for field blank, upper Prickly Pear Creek watershed, Montana

[Samples collected by the U.S. Geological Survey. Abbreviations: ${ }^{0} \mathrm{C}$, degrees Celsius; lab, laboratory; $\mu \mathrm{g} / \mathrm{L}$, micrograms per liter; $\mu \mathrm{S} / \mathrm{cm}$, microsiemen per centimeter at $25^{\circ} \mathrm{C} ; \mathrm{mg} / \mathrm{L}$, milligrams per liter. Symbols: <, less than minimum reporting level; E, estimated]

\begin{tabular}{|c|c|c|c|c|c|c|c|c|}
\hline Date & Time & $\begin{array}{c}\text { Specific } \\
\text { conductance, } \\
\text { lab }(\mu \mathrm{S} / \mathrm{cm})\end{array}$ & \multicolumn{2}{|c|}{$\begin{array}{c}\mathrm{pH}, \text { lab } \\
\text { (standard } \\
\text { units) }\end{array}$} & $\begin{array}{c}\text { Calcium, } \\
\text { dissolved } \\
\text { (mg/L as Ca) }\end{array}$ & $\begin{array}{c}\text { Magnesium, } \\
\text { dissolved } \\
(\mathrm{mg} / \mathrm{L} \text { as } \mathrm{Mg})\end{array}$ & $\begin{array}{c}\text { Aluminum, } \\
\text { total } \\
\text { recoverable } \\
(\mu \mathrm{g} / \mathrm{L} \text { as } \mathrm{Al})\end{array}$ & \multirow{2}{*}{$\begin{array}{c}\begin{array}{c}\text { Aluminum, } \\
\text { dissolved } \\
(\mu \mathrm{g} / \mathrm{L} \text { as Al) }\end{array} \\
<1\end{array}$} \\
\hline $10-19-00$ & 0930 & E 2 & & & E 0.01 & $<0.008$ & $<2$ & \\
\hline $\begin{array}{c}\text { Antimony, } \\
\text { total } \\
\text { recoverable } \\
(\mu \mathrm{g} / \mathrm{L} \text { as } \mathrm{Sb})\end{array}$ & $\begin{array}{l}\text { Antimony, } \\
\text { dissolved } \\
(\mu \mathrm{g} / \mathrm{L} \text { as Sb) }\end{array}$ & $\begin{array}{l}\text { Arsenic, total } \\
\text { recoverable } \\
\text { ( } \mu \text { g/L as As) }\end{array}$ & \multicolumn{2}{|c|}{$\begin{array}{c}\text { Arsenic, } \\
\text { dissolved } \\
\text { ( } \mu \mathrm{g} / \mathrm{L} \text { as As) }\end{array}$} & $\begin{array}{c}\text { Cadmium, } \\
\text { total } \\
\text { recoverable } \\
\text { ( } \mu \mathrm{g} / \mathrm{L} \text { as } \mathrm{Cd})\end{array}$ & $\begin{array}{c}\text { Cadmium, } \\
\text { dissolved } \\
(\mu \mathrm{g} / \mathrm{L} \text { as } \mathrm{Cd})\end{array}$ & $\begin{array}{l}\text { Chromium, } \\
\text { dissolved } \\
\text { d) }(\mu \mathrm{g} / \mathrm{L} \text { as Cr })\end{array}$ & $\begin{array}{l}\text { Copper, total } \\
\text { recoverable } \\
(\mu \mathrm{g} / \mathrm{L} \text { as } \mathrm{Cu})\end{array}$ \\
\hline$<0.9$ & E 0.04 & $<1.9$ & \multicolumn{2}{|c|}{$<0.18$} & $<0.11$ & $<0.14$ & $<0.8$ & $<1$ \\
\hline $\begin{array}{c}\text { Copper, } \\
\text { dissolved } \\
(\mu \mathrm{g} / \mathrm{L} \text { as } \mathrm{Cu})\end{array}$ & $\begin{array}{l}\text { Iron, total } \\
\text { recoverable } \\
(\mu \mathrm{g} / \mathrm{L} \text { as Fe) }\end{array}$ & $\begin{array}{c}\text { Iron, } \\
\text { dissolved } \\
(\mu \mathrm{g} / \mathrm{L} \text { as Fe })\end{array}$ & \multicolumn{2}{|c|}{$\begin{array}{l}\text { Lead, total } \\
\text { recoverable } \\
(\mu \mathrm{g} / \mathrm{L} \text { as } \mathrm{Pb})\end{array}$} & $\begin{array}{c}\text { Lead, } \\
\text { dissolved } \\
(\mu \mathrm{g} / \mathrm{L} \text { as } \mathrm{Pb})\end{array}$ & $\begin{array}{c}\text { Manganes } \\
\text { total } \\
\text { recoverabl } \\
(\mu \mathrm{g} / \mathrm{L} \text { as } \mathrm{M}\end{array}$ & $\begin{array}{cc}\text { e, } & \text { Manganese, } \\
\text { dissolved } \\
\text { le } \\
\text { n) }\end{array}$ & $\begin{array}{c}\text { Mercury, total } \\
\text { recoverable } \\
(\mu \mathrm{g} / \mathrm{L} \text { as } \mathrm{Hg})\end{array}$ \\
\hline 0.38 & $<14$ & $<10$ & & & 0.12 & $<2.8$ & $<1$ & $<0.14$ \\
\hline $\begin{array}{c}\text { Mercury, } \\
\text { dissolved }(\mu \mathrm{g} / \mathrm{L} \\
\text { as } \mathrm{Hg})\end{array}$ & $\begin{array}{l}\text { Nickel, tota } \\
\text { recoverable } \\
(\mu \mathrm{g} / \mathrm{L} \text { as } \mathrm{Ni})\end{array}$ & \multicolumn{2}{|c|}{$\begin{array}{c}\text { Nickel, } \\
\text { dissolved }(\mu \mathrm{g} / \mathrm{L} \\
\text { as } \mathrm{Ni})\end{array}$} & \multicolumn{2}{|c|}{$\begin{array}{l}\text { Silver, total } \\
\text { recoverable } \\
(\mu \mathrm{g} / \mathrm{L} \text { as } \mathrm{Ag})\end{array}$} & $\begin{array}{l}\text { Silver, } \\
\text { dissolved }(\mu \mathrm{g} / \mathrm{L} \\
\text { as Ag) }\end{array}$ & $\begin{array}{l}\text { Zinc, total } \\
\text { recoverable } \\
\text { ( } \mu \text { g/L as } Z n)\end{array}$ & $\begin{array}{l}\text { Zinc, dissolved } \\
(\mu \mathrm{g} / \mathrm{L} \text { as } \mathrm{Zn})\end{array}$ \\
\hline$<0.23$ & $<1$ & E0.0 & & & 1 & $<0.16$ & $<1$ & $<1$ \\
\hline
\end{tabular}


Appendix 5. Field numbers, site descriptions, sample descriptions, latitude and longitude, and field measurements of streambed sediment localities in the upper Prickly Pear Creek watershed.

[Samples collected October 2000 by David Fey and Terry Klein, USGS. Latitude in north, longitude is west. Conductivity in $\mu \mathrm{S} / \mathrm{cm}$, alkalinity and hardness in ppm $\left(\mathrm{CaCO}_{3}\right)$, iron measurements in ppm $(\mathrm{mg} / \mathrm{L})]$

\begin{tabular}{|c|c|c|c|c|c|c|c|c|c|}
\hline \multicolumn{2}{|c|}{ Field No. Site description } & \multirow{2}{*}{$\begin{array}{l}\text { Sample Description } \\
\text { sand and gravel }\end{array}$} & \multicolumn{2}{|c|}{$\begin{array}{l}\text { latitude longitude pH } \\
\text { degrees degrees }\end{array}$} & \multirow{2}{*}{$\begin{array}{r}\text { conductivity } \\
135\end{array}$} & \multicolumn{2}{|c|}{$\begin{array}{c}\text { total total } \\
\text { alkalinity hardness }\end{array}$} & \multicolumn{2}{|c|}{$\begin{array}{l}\text { soluble total } \\
\text { iron iron }\end{array}$} \\
\hline B-1 & Beavertown Creek above Prickly Pear Creek & & $46.3760-112.0306$ & 7.67 & & 80 & 180 & & 0.4 \\
\hline B-100 & upper Beavertown Creek & sand & $46.3490-112.0469$ & 7.43 & 173 & & & & \\
\hline $\mathrm{C}-1$ & upper South Fork Quartz Creek & monzonite sand and gravel & $46.4047-112.1824$ & 7.23 & 115 & & & & \\
\hline $\mathrm{C}-2$ & Quartz Creek below North and South Forks & medium sand & $46.4080-112.1344$ & 7.60 & 192 & & & & \\
\hline C-3 & Kady Gulch & coarse and medium sand & $46.3856-112.1414$ & 7.25 & 183 & & & & \\
\hline C-4 & Clancy Creek above Quartz Creek & sand and gravel & $46.4023-112.1194$ & dry & 246 & & & & \\
\hline C-5 & Clancy Creek below Quartz Creek & coarse and medium sand & $46.4110-112.1139$ & 7.50 & 1222 & & & & \\
\hline C-6 & Clancy Creek above Prickly Pear Creek & coarse and medium sand & $46.4658-111.9856$ & 7.78 & 151 & 90 & 140 & 0.0 & \\
\hline C-100 & tributary to Clancy Creek from Gregory Mountain & medium sand & $46.3889-112.1186$ & 3.96 & 142 & $<50$ & 400 & 4.0 & \\
\hline C-101 & upper Clancy Creek & medium sand & $46.3833-112.1301$ & 7.15 & 184 & $<50$ & 105 & 0.0 & \\
\hline C-102 & North Fork Quartz creek above South Fork & sand and gravel & $46.4102-112.1475$ & 7.46 & 145 & & & & \\
\hline C-103 & South Fork Quartz creek above North Fork & sand and gravel, some Mn-oxide & $46.4083-112.1492$ & 7.52 & 105 & & & & \\
\hline C-104 & South Fork Quartz creek & sand and gravel & $46.4077-112.1599$ & 7.56 & 86 & $<50$ & $<100$ & 0.0 & \\
\hline $\mathrm{D}-1$ & Dutchman Creek above Prickly Pear Creek & medium sand & $46.4167-111.9997$ & 7.32 & 67 & & & & \\
\hline G-1 & Golconda Gulch above Warm Springs Creek & sand and gravel & $46.3655-112.0062$ & 7.45 & 74 & & & & \\
\hline L-1 & south tributary to upper Lump Gulch & sand and gravel & $46.4291-112.2061$ & 6.92 & 510 & & & & \\
\hline L-2 & upper Lump Gulch, above mines & sand & $46.4415-112.2064$ & 6.97 & 402 & & $<110$ & & 0.0 \\
\hline L-3a & north outlet of lower Frohner Meadow & sediment below meadow, Mn-oxide & $46.4341-112.1896$ & 6.27 & 108 & & & & \\
\hline$L-3 b$ & south outlet of lower Frohner Meadow & sediment below meadow & $46.4367-112.1879$ & 6.27 & 186 & & 230 & & 0.4 \\
\hline L-4 & below impoundment on upper Lump Gulch & silt, fine sand, muck & $46.4368-112.1722$ & 6.82 & 124 & & & & \\
\hline L-4a & above impoundment on upper Lump Gulch & sandy, Fe-oxide & $46.4354-112.1767$ & 6.65 & 232 & & & & \\
\hline L-5 & Lump Gulch above Corral Gulch & sand and gravel & $46.4576-112.1067$ & 6.93 & 133 & & & & \\
\hline L-6 & Corral Gulch above Lump Gulch & coarse sand & $46.4602-112.1053$ & 6.89 & 270 & & & & \\
\hline L-7 & Lump Gulch above Buffalo Creek & sand and grave & $46.4775-112.0749$ & 7.20 & 180 & & & & \\
\hline L-8 & Buffalo Creek above Lump Gulch & sand and gravel & $46.4787-112.0742$ & 7.31 & 89 & & & & \\
\hline
\end{tabular}




\begin{tabular}{|c|c|c|c|c|c|c|c|c|}
\hline \multicolumn{2}{|c|}{ Field No. Site description } & \multirow{2}{*}{$\begin{array}{l}\text { Sample Description } \\
\text { sand and gravel }\end{array}$} & $\begin{array}{l}\text { latitude longitude pH } \\
\text { degrees degrees }\end{array}$ & conductivity & \multicolumn{2}{|c|}{$\begin{array}{c}\text { total total } \\
\text { alkalinity hardness }\end{array}$} & \multicolumn{2}{|c|}{ soluble total } \\
\hline L-9 & Lump Gulch below Little Buffalo Gulch & & $46.4846-112.0377 \quad 7.70$ & 72 & & 100 & & 0.1 \\
\hline L-100 & Lump Gulch east of Frohner mine & Sand and gravel & $46.4428-112.1994 \quad 6.85$ & 89 & $<50$ & $<100$ & 0.2 & 2.0 \\
\hline PP-1 & upper Prickly Pear Creek & sand and gravel & $46.3590-111.97307 .50$ & 72 & & & & \\
\hline PP-2 & Prickly Pear Creek above Beavertown Creek & sand and gravel & $46.3741-112.02407 .45$ & 257 & $<50$ & $<100$ & 0.0 & \\
\hline PP-3 & Prickly Pear Creek between Beavertown and Dutchman Creeks & medium sand & $46.4019-112.01447 .98$ & 271 & & & & \\
\hline PP-4 & Prickly Pear Creek below Warm Springs Creek & medium sand, mod. Fe-oxide & $46.4550-111.98417 .93$ & 110 & 80 & $<100$ & 0.0 & \\
\hline PP-5 & Prickly Pear Creek at USGS gauging station & medium sand & $46.5192-111.9458 \quad 8.18$ & 270 & & & & \\
\hline S-1 & Wood Chute Gulch, upper Spring Creek tributary & medium sand & $46.3478-112.1667 \quad 7.51$ & & & & & \\
\hline S-1a & Curtain Gulch, upper Spring Creek tributary & sand, w/ Fe-oxide coatings & $46.3563-112.16197 .05$ & 556 & & 150 & 0.2 & 9.0 \\
\hline S-2 & upper Spring Creek & medium sand from burn area & $46.3410-112.1321$ dry & 471 & & & & \\
\hline S-3 & Spring Creek above Corbin & sand & $46.3763-112.06327 .50$ & & & & & \\
\hline S-4 & Spring Creek above Jefferson City & sand and gravel, Mn-oxide & $46.3889-112.02727 .98$ & & 80 & 300 & & 0.0 \\
\hline S-100 & Wood Chute Gulch, above Spring Creek & coarse sand, Mn-oxide & $46.3477-112.1377$ dry & & & & & \\
\hline S-101 & tributary to Spring Creek, above Corbin & sand & $46.3815-112.0806$ dry & 87 & & & & \\
\hline S-102 & tributary to Spring Creek, above Corbin & sand, possible alkali salts & $46.3803-112.0847$ dry & 226 & & & & \\
\hline WS-1 & upper Middle Fork Warm Springs Creek & coarse and medium sand & $46.4194-111.8840 \quad 6.86$ & 199 & & & & \\
\hline WS-2 & upper Middle Fork Warm Springs Creek & sand and gravel & $46.4172-111.89397 .95$ & 217 & 75 & 120 & 0.0 & \\
\hline WS-2a & upper Middle Fork Warm Springs Creek & tailings impacted sand & $46.4178-111.89697 .47$ & 181 & 125 & 75 & 0.0 & \\
\hline WS-3 & Middle Fork Warms Springs Creek above North Fork & grus and rhyolite derived sand & $46.4226-111.9277 \quad 7.72$ & 90 & 75 & 130 & 0.0 & \\
\hline WS-4 & North Fork Warm Springs Creek & sand & $46.4246-111.92907 .67$ & 137 & & & & \\
\hline WS-5 & South Fork Warms Springs Creek & sand and gravel & $46.4197-111.94567 .58$ & 93 & & & & \\
\hline WS-7 & Warm Springs Creek above Prickly Pear Creek & sand and gravel & $46.4425-111.96697 .70$ & 102 & 50 & $<100$ & 0.0 & \\
\hline WS-100 & unnamed tributary above upper Middle Fork Warms Springs Creek & sand and gravel, weak Fe-oxide & $46.4200-111.88696 .45$ & 265 & & & & \\
\hline WS-101 & unnamed tributary south of upper Middle Fork Warm Springs Creek & sand & $46.4165-111.89316 .82$ & & & & & \\
\hline WS-102 & unnamed tributary south of upper Middle Fork Warm Springs Creek & medium and fine sand, some Fe-oxide & $46.4166-111.89227 .79$ & & & & & \\
\hline WS-103a & apper Middle Fork Warm Springs Creek & composite fluvial tailings & $46.4178-111.8969$ dry & & & & & \\
\hline WS-103b & opper Middle Fork Warm Springs Creek & 4 inches of soil over fluvial tailings & $46.4178-111.8969$ dry & & & & & \\
\hline
\end{tabular}


Appendix 6. Mixed acid total digestion ICP-AES results from streambed sediments collected October 2000 from the upper Prickly Pear Creek watershed. [Analyzed by David Fey, USGS]

\begin{tabular}{|c|c|c|c|c|c|c|c|c|c|c|c|c|c|c|c|c|c|c|c|c|c|c|c|c|}
\hline eld No. & $\begin{array}{c}\mathbf{A g} \\
\mathrm{ppm}\end{array}$ & $\begin{array}{l}\text { Al } \\
\%\end{array}$ & $\begin{array}{c}\text { As } \\
\mathrm{ppm}\end{array}$ & $\left|\begin{array}{c}\mathbf{B a} \\
\mathrm{ppm}\end{array}\right|$ & $\begin{array}{c}\text { Be } \\
\text { ppm }\end{array}$ & $\begin{array}{l}\mathrm{Ca} \\
\%\end{array}$ & \begin{tabular}{c|}
$\mathbf{C d}$ \\
$\mathrm{ppm}$
\end{tabular} & \begin{tabular}{|c|} 
Co \\
ppm
\end{tabular} & $\mid \begin{array}{c}\mathbf{C r} \\
\text { ppm }\end{array}$ & $\begin{array}{c}\mathrm{Cu} \\
\mathrm{ppm}\end{array}$ & $\begin{array}{c}\mathrm{Fe} \\
\%\end{array}$ & $\begin{array}{l}\mathbf{K} \\
\%\end{array}$ & $\begin{array}{c}\mathbf{M g} \\
\%\end{array}$ & $\begin{array}{c}\text { Mn } \\
\text { ppm }\end{array}$ & \begin{tabular}{|c|} 
Mo \\
Ppm
\end{tabular} & $\begin{array}{c}\mathrm{Na} \\
\%\end{array}$ & $\begin{array}{c}\mathbf{N i} \\
\text { ppm }\end{array}$ & $\begin{array}{l}\mathbf{P} \\
\%\end{array}$ & \begin{tabular}{|c|}
$\mathbf{P b}$ \\
$\mathrm{ppm}$
\end{tabular} & $\begin{array}{l}\mathrm{Ti} \\
\%\end{array}$ & $\begin{array}{c}\mathrm{Sr} \\
\mathrm{ppm}\end{array}$ & $\begin{array}{c}\text { Th } \\
\text { ppm }\end{array}$ & \begin{tabular}{c|}
$\mathbf{v}$ \\
$\mathrm{ppm}$
\end{tabular} & $\begin{array}{c}\text { Zn } \\
\text { ppm }\end{array}$ \\
\hline B-1 & $<2$ & 7.5 & 14 & 820 & 2 & 1.8 & 6 & 14 & 36 & 130 & 5.6 & 2.9 & 0.60 & 3,900 & 11 & 1.7 & 19 & 0.13 & 58 & 0.26 & 470 & 54 & 130 & 1,100 \\
\hline B-100 & $<2$ & 7.5 & 15 & 590 & 2 & 2.4 & 3 & 14 & 19 & 110 & 3.6 & 2.7 & 1.1 & 1,500 & 0 & 1.8 & 15 & .15 & 36 & 0.42 & 390 & 32 & 86 & 140 \\
\hline C-1 & $<2$ & 8.0 & 44 & 690 & 2 & 2.2 & 15 & 23 & 50 & 59 & 6.9 & 2.4 & 0.90 & 4,200 & 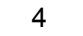 & 1.7 & 20 & 0.15 & 340 & 0.54 & 370 & 33 & 210 & 1,800 \\
\hline C-2 & $<2$ & 8.4 & 14 & 840 & 2 & 2.5 & 5 & 10 & 25 & 21 & 3.8 & 2.6 & 0.81 & 2,800 & 2 & 2.4 & 13 & 0.16 & 63 & 0.37 & 510 & 31 & 99 & 580 \\
\hline C-3 & $<2$ & 7.6 & 51 & 820 & 2 & 1.4 & 12 & 14 & 43 & 50 & 5.1 & 3.1 & 0.78 & 7,100 & 1 & 0.90 & 21 & 0.12 & 230 & 0.38 & 290 & 23 & 140 & 1,400 \\
\hline C-4 & 11 & 6.9 & 1,300 & 790 & 3 & 1.4 & 51 & 22 & 60 & 700 & 5.8 & 2.5 & 0.73 & 12,000 & 3 & $1 .($ & 35 & 0.16 & 1,400 & 0.26 & 280 & 15 & 150 & 7,400 \\
\hline C-5 & $<2$ & 8.1 & 120 & 760 & 2 & 2.2 & 8 & 10 & 28 & 63 & 3.8 & 2.9 & 0.72 & 1,700 & $<2$ & 2.2 & 13 & 0.14 & 170 & 0.32 & 480 & 29 & 110 & 760 \\
\hline C-6 & $<2$ & 8.0 & 37 & 700 & 2 & 2.4 & 7 & 20 & 44 & 42 & 7.0 & 2.3 & 0.79 & 980 & $<2$ & 2.2 & 15 & 0.16 & 95 & 0.34 & 470 & 32 & 210 & 480 \\
\hline C-100 & 7 & 7.4 & 730 & 1,000 & 2 & 0.76 & 4 & 7 & 30 & 88 & 4.3 & 3.2 & 0.50 & 660 & $<2$ & 1.6 & 11 & 0.09 & 450 & 0.24 & 380 & 13 & 66 & 400 \\
\hline C-101 & $<2$ & 7.5 & 49 & 890 & 2 & 1.5 & 5 & 20 & 60 & 70 & 4.8 & 2.6 & 1.2 & 3,200 & $<2$ & 0.78 & 22 & 0.11 & 100 & 0.33 & 310 & 10 & 130 & 840 \\
\hline C-102 & 2 & 8.2 & $<10$ & 790 & 2 & 2.1 & 4 & 12 & 40 & 13 & 5.6 & 2.1 & 0.50 & 880 & $<2$ & 2.8 & 11 & .14 & 32 & 0.26 & 570 & 17 & 60 & 0 \\
\hline C-103 & $<2$ & 8.1 & 49 & 950 & 2 & 2.4 & 12 & 18 & 3 & 43 & 5.8 & 2.7 & 0.82 & & 2 & & 1 & 6 & 150 & 0.40 & 440 & 33 & 50 & 1,800 \\
\hline C-104 & $<2$ & 7.6 & 36 & 710 & 2 & 2.0 & 12 & 18 & 4 & 5. & 5.6 & 2.5 & 0.80 & & 3 & & 1 & & 180 & & 420 & 24 & 30 & 1,200 \\
\hline $\mathrm{D}$ & $<2$ & 7.4 & $<10$ & 640 & 2 & 2 & 6 & 2 & 5 & 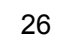 & 8.9 & 2.0 & 0.83 & & 7 & & 1 & & 20 & & 480 & 140 & 30 & 7 \\
\hline G & 4 & 7.3 & 100 & 480 & 2 & & 8 & 2 & 4 & 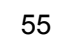 & 8.5 & 2.4 & 1.1 & & 6 & & $T$ & & 840 & & 310 & 120 & 30 & 0 \\
\hline L & $<2$ & 9.3 & 18 & & 2 & & 3 & & 1 & & & 2.1 & 0.34 & & $<2$ & & & & - & & 670 & 22 & 0 & 0 \\
\hline L & $<2$ & 8.9 & 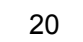 & & 2 & & 3 & $<$ & 1 & & & 1.9 & & & $<2$ & & & & & & 660 & 16 & 51 & \\
\hline L-3 & $<2$ & 8.1 & 400 & 1,000 & 2 & & 5 & 3 & 10 & & & 2.0 & 0.31 & 1 & 23 & & & & 180 & & 650 & 1 & 51 & 0 \\
\hline L & 4 & 6.7 & 1,600 & & 3 & & & & 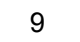 & & & & & & 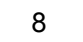 & & & & 660 & & & 8 & $r$ & \\
\hline L & $<$ & 7.8 & 30 & & 3 & & 1 & 1 & 2 & & & & & & 3 & & & & & & 0 & 9 & 20 & \\
\hline $\mathrm{L}-$ & $<$ & 9 & 8 & & 2 & & & $r$ & & & & & & & 2 & & & & & & & & & \\
\hline $\mathrm{L}$ & $<2$ & 7.2 & 20 & & 2 & & 11 & 3 & 0 & 2 & & & & & 2 & & & & 9 & 0.27 & & 8 & 0 & \\
\hline 1. & $<2$ & 8.4 & $<10$ & 700 & 2 & 2 & 4 & 1 & 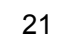 & 3 & 4. & 2.6 & 0.65 & 1,600 & 7 & 2 & 1 & 0 & 24 & 0.30 & 600 & 39 & 30 & 74 \\
\hline 1 & $<2$ & 7.2 & 16 & 720 & 2 & 2 & 11 & 4 & 8 & 2 & 14 & 2.1 & 0.62 & 92 & 2 & 2. & 1 & 0. & 40 & 0.32 & 460 & 94 & 430 & 510 \\
\hline L & $<2$ & 7.2 & 14 & 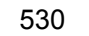 & 2 & 2. & 4 & 27 & 4 & 5 & 6.5 & 2.0 & 1.0 & 2,5 & 13 & 1. & 1 & 0.1 & 17 & 0.53 & 440 & 23 & 200 & 110 \\
\hline & $<2$ & 4.9 & 16 & 750 & $<1$ & 2. & 20 & 9 & 210 & 27 & 30 & 1.4 & 0.66 & 1,7 & 3 & 1. & 3 & 0.24 & 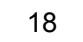 & 0.52 & 290 & 230 & 1000 & 310 \\
\hline L-100 & 45 & 7.6 & 3,900 & 1,000 & 3 & 0.99 & 110 & 140 & 0 & 400 & 5.8 & 1.9 & 0.27 & 29 & 9 & 1. & 3 & 0.06 & 4,900 & 0.09 & 390 & 24 & 44 & 7,700 \\
\hline PP-1 & $<2$ & 7.1 & 15 & 590 & 2 & 3.4 & 4 & 22 & 130 & 23 & 5.4 & 2.5 & 2.1 & & 2 & 1. & 3 & 0.16 & 25 & 0.60 & 420 & 43 & 60 & 150 \\
\hline PP-2 & $<2$ & 7.2 & 21 & 550 & 2 & 3. & 5 & 15 & 69 & 29 & 4. & 2.4 & 1.3 & 1,000 & 2 & & 20 & 0.14 & 120 & 0.43 & 410 & 60 & 40 & 240 \\
\hline PP-3 & 15 & 5.9 & 390 & 620 & 2 & 1.5 & 19 & 9 & 39 & 420 & 4.6 & 2.1 & 0.62 & 10,000 & 6 & 1. & 16 & 0.11 & 2,400 & 0.28 & 270 & 30 & 20 & 3,300 \\
\hline PP-4 & 5 & 7.6 & 110 & 620 & 3 & 2.3 & 11 & 10 & 25 & 150 & 3.8 & 2.4 & 0.89 & 2,800 & 2 & 1. & 1 & 0.12 & 580 & 0.35 & 440 & 36 & 100 & 1,900 \\
\hline PP-5 & 2 & 6.6 & 59 & 680 & 2 & 2.8 & 12 & 42 & 140 & 71 & 14 & 1.8 & 0.98 & 2,200 & 3 & 1.8 & 22 & 0.26 & 230 & 0.61 & 380 & 150 & 470 & 910 \\
\hline S-1 & $<2$ & 7.2 & 55 & 800 & 1 & 1.2 & 4 & 20 & 50 & 40 & 4.5 & 2.6 & 1.4 & 1,100 & $<2$ & 0.66 & 18 & 0.13 & 68 & 0.42 & 250 & 9 & 140 & 180 \\
\hline
\end{tabular}




\begin{tabular}{|c|c|c|c|c|c|c|c|c|c|c|c|c|c|c|c|c|c|c|c|c|c|c|c|c|}
\hline & $\begin{array}{r}\mathbf{A g} \\
\mathrm{ppm}\end{array}$ & $\begin{array}{l}\text { Al } \\
\%\end{array}$ & $\begin{array}{r}\text { As } \\
\text { ppm }\end{array}$ & $\begin{array}{c}\text { Ba } \\
\text { ppm }\end{array}$ & $\begin{array}{c}\text { Be } \\
\text { ppm }\end{array}$ & $\begin{array}{l}\mathrm{Ca} \\
\%\end{array}$ & $\begin{array}{c}\text { Cd } \\
\text { ppm }\end{array}$ & $\begin{array}{c}\text { Co } \\
\text { ppm }\end{array}$ & $\begin{array}{c}\mathbf{C r} \\
\mathrm{ppm}\end{array}$ & $\begin{array}{c}\mathrm{Cu} \\
\mathrm{ppm}\end{array}$ & 6 & $\%$ & $\begin{array}{c}\mathbf{M g} \\
\%\end{array}$ & $\begin{array}{r}\text { Mn } \\
\text { ppm }\end{array}$ & $\begin{array}{c}\text { Mo } \\
\text { ppm }\end{array}$ & $\begin{array}{l}\mathrm{Na} \\
\%\end{array}$ & $\begin{array}{l}\mathbf{N i} \\
\mathrm{pm}\end{array}$ & $\begin{array}{l}\mathbf{P} \\
\%\end{array}$ & $\begin{array}{l}\mathrm{Pb} \\
\mathrm{pm}\end{array}$ & $\begin{array}{l}\mathrm{Ti} \\
\%\end{array}$ & $\begin{array}{c}\text { Sr } \\
\text { ppm }\end{array}$ & $\begin{array}{c}\text { Th } \\
\text { ppm }\end{array}$ & $\begin{array}{c}\mathbf{V} \\
\mathrm{ppm}\end{array}$ & $\begin{array}{l}\text { Zn } \\
p m m\end{array}$ \\
\hline & 53 & 6.4 & 820 & 800 & $?$ & 0.76 & 40 & 120 & 20 & 00 & 10 & 2 & 9 & 2 & & 0.35 & 19 & 3 & 0 & 0.01 & & 24 & & 200 \\
\hline & & & 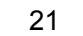 & & & & & & & & & & & & & & & & & & & & & \\
\hline & & & 2 & & & & & & & & & & & & & & & & & & & 2 & & \\
\hline & 0 & 0 & 780 & & 0 & & & & & & 3 & & & & & & & & & & & 5 & & \\
\hline & & 7.6 & 500 & & 2 & & & $c^{2}$ & & & 7.0 & & & & 3 & & & & & 0.22 & & 0 & & \\
\hline & 4 & 7.7 & 50 & 660 & & & & 0 & & & 1 & & & & $<2$ & & & & & 0.56 & & 39 & & \\
\hline & 5 & 8.2 & 46 & 60 & & & & 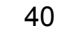 & & & & & & & 2 & & & & & 0.25 & & 2 & & \\
\hline & & & 18 & & & & & & & & 1 & & & & $<2$ & & & & & & & 5 & & \\
\hline & & 0 & & & & & & & & & & & & & ? & & & & & 0.60 & & 6 & & \\
\hline & & 3 & 1,700 & 10 & & & & & & & & 2.4 & 0.95 & & & & & & & 0.49 & 200 & 14 & & \\
\hline & $<2$ & 7.2 & 850 & 490 & & & & & & & 7.1 & 2.7 & 1. & & & & & & 300 & 0.61 & 270 & 5 & & 1,800 \\
\hline & $<2$ & 7.9 & & 520 & & & & & & & 4. & & 1. & & 2 & & & & & 0.42 & & 6 & & \\
\hline & $<2$ & 7.0 & 15 & & & & & & & & 9 & 1.8 & 1. & & $<2$ & & & & & 0.65 & 390 & 38 & & \\
\hline & $<2$ & 7.1 & & & & & 5 & & & & & 2.4 & 0.98 & & 2 & & & & & 0.44 & 350 & 39 & & 430 \\
\hline & $<2$ & 7.0 & 20 & & & & 6 & & & 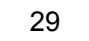 & & 2.6 & 1. & & & & & & & 0.88 & $2 \varepsilon$ & 7 & & 0 \\
\hline & $<2$ & 7.0 & 26 & & & & & & & & & 2. & & & & & & & & 0.96 & 3 & 4 & & \\
\hline & 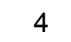 & & 2,40 & 48 & 3 & & & 4. & & & 6 & 2. & & & 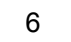 & & 30 & & 50 & 0.54 & 320 & 30 & 160 & 700 \\
\hline & 6 & & & 31 & 2 & & 5 & 2 & & & & 3. & & & 6 & & & & & $0 . \angle 2$ & & 25 & 69 & \\
\hline WS-103b & 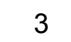 & 6.5 & 3,000 & 410 & 3 & 1.4 & 16 & 26 & 29 & 160 & 4.9 & 2.6 & 0.92 & 2,300 & 13 & 0.90 & 15 & 0.10 & 500 & 0.40 & 190 & 29 & 120 & 1,300 \\
\hline
\end{tabular}


Appendix 7. Results of NURE streambed sediment sample reanalysis by ICP-AES using mixed acid total digestion from the upper Prickly Pear Creek watershed.

[Analyzed by David Fey, USGS]

\begin{tabular}{|c|c|c|c|c|c|c|c|c|c|c|c|c|c|c|c|c|c|c|c|c|c|c|c|c|c|c|c|c|c|}
\hline o & ID & Lat & Long & $\begin{array}{l}\text { Al } \\
\%\end{array}$ & $\begin{array}{l}\mathrm{Ca} \\
\%\end{array}$ & $\begin{array}{l}\mathrm{Fe} \\
\%\end{array}$ & $\begin{array}{l}\mathbf{K} \\
\%\end{array}$ & $\begin{array}{c}\mathrm{Mg} \\
\%\end{array}$ & $\%$ & $\begin{array}{r}\mathbf{P} \\
\%\end{array}$ & $\begin{array}{l}\mathrm{Ti} \\
\%\end{array}$ & $\begin{array}{l}\mathrm{Ag} \\
\mathrm{pm}\end{array}$ & $\begin{array}{c}\text { As } \\
\mathrm{ppm}\end{array}$ & $\begin{array}{c}\mathrm{Ba} \\
\mathrm{ppm}\end{array}$ & $\begin{array}{c}\mathrm{Be} \\
\mathrm{ppm}\end{array}$ & $\begin{array}{c}\text { Cd } \\
\text { ppm }\end{array}$ & $\begin{array}{c}\text { Co } \\
\text { ppm }\end{array}$ & $\begin{array}{c}\mathrm{Cr} \\
\mathrm{ppm}\end{array}$ & $\begin{array}{c}\mathrm{Cu} \\
\mathrm{ppm}\end{array}$ & $\begin{array}{c}\mathbf{L i} \\
\mathrm{ppm}\end{array}$ & $\begin{array}{l}\text { Mn } \\
\text { ppm }\end{array}$ & $\begin{array}{c}\text { Mo } \\
\text { ppm }\end{array}$ & $\begin{array}{l}\mathrm{Ni} \\
\mathrm{pmm}\end{array}$ & $\begin{array}{c}\mathbf{P b} \\
\mathrm{ppm}\end{array}$ & $\begin{array}{l}\text { Sc } \\
\text { ppm }\end{array}$ & $\mathrm{Sr}$ & ppm & $\mathbf{V}$ & $\begin{array}{c}\mathrm{Zn} \\
\mathrm{ppm}\end{array}$ \\
\hline 33 & 23214 & 883 & & 7.6 & 30 & 32 & 21 & 12 & 20 & 14 & ת? & & & 40 & 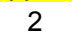 & 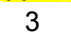 & & 20 & & 19 & 810 & $<2$ & 13 & 27 & in & 100 & 30 & 87 & 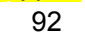 \\
\hline & & & & & & & & & & & & & & & & & & & & & & & & & & & & & 34 \\
\hline & & & & & & & & & & & & & & & & & & & & & & & & & & & & & 60 \\
\hline & & & & & & & & & & & & & & & & & & & & & & & & & & & & & 68 \\
\hline & & & & & & & & & & & & & & & & & & & & & & 2 & & & & & & & 140 \\
\hline & & & & & & & & & & & & & & & & & & & & & & $<2$ & & & & & & & 130 \\
\hline & & & & 37.2 & & & & & & & & & & & & & & & & & & 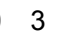 & & & & & & & 650 \\
\hline & & & & 7.2 & & & & & & & & & & & & & & & & & & $\checkmark$ & & & & & & & 450 \\
\hline & & & & 8.2 & & & & & & & & & & & & & & & & & & & & & & & - & & 100 \\
\hline & & & & 8.0 & .0 & & 2.2 & & & & & & & & & & & & & & & 3 & & & & & 8 & 0 & 140 \\
\hline & & & & & & & 9 & & & & & & & & & & & & & & & 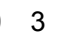 & 2 & & & & & 50 & 1,400 \\
\hline & & & & 8.0 & & & 20 & & & & & 5 & & & & & & & & & & $<2$ & 15 & & & & & 56 & 120 \\
\hline & & & & 8 & & & & & & & & ? & & & & & & & & & & 120 & 10 & & & & & & 69 \\
\hline & & & & 3.9 & & & & & & & & & & & & & & & & & & $<2$ & 28 & & & & & & 7,600 \\
\hline & & & & 7.4 & 0.94 & & & & & & & & & & & & & & & & & 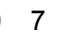 & 10 & & & & & 4 & 1,700 \\
\hline & & & & 7.0 & & & & & & & & & & & & & & & & & & $<2$ & & & & & 8 & 240 & 120 \\
\hline & & & & 5.8 & & & & & & & & & & & & & & & & & & 26 & 30 & & & & 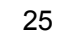 & 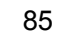 & 250 \\
\hline & & & & 58.1 & & & & & & & & 7 & & & & & & & & & & $<2$ & 13 & & & 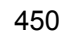 & 28 & 100 & 1,200 \\
\hline & & & & 7.4 & & & & & & & & & & & & & & & & 21 & & 2 & 150 & & & & & 30 & 110 \\
\hline & & & & 7.6 & & & & & & & & & & & & & & & & & (0) & $<2$ & 1 & & & 0 & 100 & & 64 \\
\hline & & & & 77. & & & & & & & & & & & & & & & & & & 4 & & & & & & & 69 \\
\hline & & & & 0 & & & & & & & & & & & & & & & & & & $<2$ & & & & & & & 180 \\
\hline & & & & 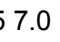 & & & & & & & & & & & & & & & & & & $<2$ & & & & & & & 140 \\
\hline & & & & 8.6 & $0.0^{2}$ & 4. & & & & & & & & & & & & & & & & 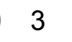 & 20 & & & 0 & Do & 130 & 100 \\
\hline & 2020048 & 46.4786 & & 6.7 & 3.1 & & ... & 1.6 & $\cdots$ & . & r. & 2 & & 510 & 2 & 6 & -0 & 78 & 24 & 27 & 1,300 & $<2$ & 21 & - & 24 & 350 & 120 & 270 & 96 \\
\hline
\end{tabular}


Appendix 8. 2M HCL-1\% hydrogen peroxide partial-digestion ICP-AES results from streambed sediments collected October 2000 from the upper Prickly Pear Creek watershed. [Analyzed by David Fey, USGS]

\begin{tabular}{|l|l|l|l|l|l|l|l|l|l|l|l|l|l|l|l|l|l|l|l|l|l|l|l|l|l|l|l|l|l} 
Ag/P & Al/P & As/P & B/P & Ba/P & Be/P & Ca/P & Cd/P & Co/P & Cr/P & Cu/P & Fe/P & K/P & Li/P & Mg/P & Mn/P & Mo/P & Na/P & Ni/P & P/P & Pb/P & Sb/P & Si/P & Sr/P & Ti/P & V/P & Zn/P \\
\hline
\end{tabular}

\begin{tabular}{|c|c|c|c|c|c|c|c|c|c|c|c|c|c|c|c|c|c|c|c|c|c|c|c|c|c|c|c|}
\hline eld No. & om & $\mathrm{ppm}$ & ppm & ppm & $\mathrm{pm}$ & ppm & $\mathrm{ppm}$ & ppm & $\mathrm{ppm}$ & ppm & ppm & $\mathrm{ppm}$ & ppm & $\mathrm{pm}$ & $\mathrm{ppm}$ & ppm & ppm & $\mathrm{ppm}$ & ppm & $\mathrm{pm}$ & ppm & ppm & ppm & ppm & opm & $\mathrm{ppm}$ & $\mathrm{ppm}$ \\
\hline B-1 & 0.3 & 2,500 & 8.4 & 2.1 & 180 & 0.51 & 5,100 & 4.3 & 8.7 & 1.8 & 85 & 17,000 & 780 & 2.2 & 1,900 & 4,000 & 2.8 & 84 & 14 & 1,300 & 32 & $<2$ & 2,200 & 55 & 66 & 13 & 1,200 \\
\hline B-100 & .3 & 400 & 14 & 1.6 & 00 & 41 & 4,900 & 1.4 & 7.6 & 6.3 & 76 & 4,000 & 1,400 & 4.2 & 2,700 & 1,100 & 2 & 76 & 7 & ,400 & 31 & $<2$ & ,900 & 30 & 240 & 18 & 10 \\
\hline C-1 & 0.8 & 4,200 & 16 & 1.8 & 100 & .52 & 5,100 & 11 & 9.2 & 3.5 & 36 & 16,000 & 780 & 4.5 & 2,200 & 3,300 & 1.1 & 43 & 9.5 & , 100 & 280 & $<2$ & 1,700 & 29 & 250 & 22 & 1,400 \\
\hline C-2 & 33 & 3,700 & 9.9 & 1.6 & 170 & .31 & 5,000 & 3 & 6.5 & 3.7 & 16 & 13,000 & 920 & 5.1 & 2,600 & 2,400 & 0.74 & 44 & 6.4 & ,300 & 50 & $<2$ & 1,700 & 25 & 290 & 17 & 470 \\
\hline$C-3$ & .83 & 200 & 24 & 2.3 & 190 & 0.9 & 5,700 & 9.3 & 7.9 & 4.4 & 35 & 16,000 & 1,200 & 4.5 & 2,800 & 6,600 & 0.65 & 74 & 13 & 980 & 190 & $<2$ & 1,800 & 48 & 98 & 19 & 1,300 \\
\hline C-4 & 9.3 & 6,500 & 840 & 2.6 & 200 & 1.7 & 5,400 & 51 & 14 & 4.3 & 640 & 17,000 & 1,100 & 4.4 & 2,300 & 11,000 & $<0.6$ & 68 & 27 & 1,200 & 1300 & $<2$ & 2,100 & 50 & $<2$ & 14 & 7,200 \\
\hline C-5 & .94 & 800 & 84 & 1.5 & 100 & 0.34 & 4,500 & 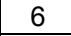 & 6.8 & 3 & 50 & 11,000 & 1,200 & 5.2 & 2,600 & 1,500 & $<0.6$ & 49 & 6.7 & ,400 & 170 & $<2$ & 1,800 & 20 & 270 & 16 & 780 \\
\hline C- 6 & 43 & 200 & 29 & 1.3 & 96 & 0.26 & 4,600 & 2.5 & 5.4 & 2.7 & 43 & 7,900 & 1,500 & 6.1 & 2,600 & 700 & $<0.6$ & 57 & 5.6 & ,400 & 75 & $<2$ & 1,500 & 20 & 370 & 15 & 410 \\
\hline C-10 & 2.3 & 3,200 & 650 & 2.7 & 71 & 0.28 & 2,000 & 2.2 & 6.5 & 2.1 & 52 & 22,000 & 710 & 2.8 & 1,600 & 540 & $<0.6$ & 65 & 4.7 & 800 & 390 & $<2$ & 1,500 & 13 & 52 & 0 & 270 \\
\hline & 1 & 100 & 13 & 1. & 80 & 49 & 3,300 & 2.1 & 8.4 & 6.5 & 37 & 12,000 & 710 & 3.8 & 2,600 & 2,300 & $<0.6$ & 43 & 9 & 650 & 64 & $<2$ & 1,300 & 26 & 2.5 & 4 & 550 \\
\hline C-102 & $<0.3$ & 2,700 & 6.3 & 1.1 & 75 & 0.29 & 3,800 & 0.73 & 4.2 & 2.6 & 12 & 8,300 & 730 & 4.2 & 1,800 & 680 & $<0.6$ & 40 & 3.9 & 1,100 & 18 & $<2$ & 1,400 & 16 & 210 & 12 & 58 \\
\hline & 78 & 300 & 32 & 3 & 380 & .43 & 6,700 & 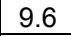 & 11 & 2.5 & 30 & & 810 & 7 & 400 & 7,800 & 0.73 & 4 & 12 & 1,500 & 120 & $<2$ & 2,200 & 50 & 190 & 21 & ,700 \\
\hline C-104 & 0.81 & 4,600 & 17 & 1.8 & 130 & 0.5 & 5,800 & 11 & 9.3 & 4.1 & 39 & 16,000 & 930 & 5.1 & 2,600 & 2,200 & 0.74 & 44 & 9.4 & 1,300 & 190 & $<2$ & 2,000 & 33 & 310 & 22 & 1,300 \\
\hline & $<0.3$ & 100 & 3.1 & 0.93 & 74 & 0.2 & 4,400 & 0.54 & 4.6 & 2.9 & 14 & 7,300 & 1,200 & 5.7 & 300 & 250 & 1 & 74 & 5 & 00 & 6.2 & $<2$ & 600 & 5 & 60 & 7 & 25 \\
\hline G-1 & 2 & 3,600 & 33 & 1.2 & 61 & 0.28 & 3,700 & 3.3 & 5 & 2.5 & 31 & 9,500 & 990 & 6 & 2,300 & 610 & 1.1 & 61 & 3.9 & 1,000 & 580 & $<2$ & 1,700 & 26 & 330 & 18 & 480 \\
\hline $\mathrm{L}-1$ & $<0.3$ & 2,900 & 12 & 0.69 & 120 & 0.35 & 3,100 & 1.3 & 3 & 1.9 & 12 & 6,800 & 430 & 4.1 & 1,200 & 480 & $<0.6$ & 38 & 2.8 & 560 & 26 & $<2$ & 1,400 & 31 & 140 & & 100 \\
\hline $\mathrm{L}-2$ & $<0.3$ & 3,800 & 16 & 1.2 & 110 & 0.38 & 4,900 & 1 & 4.1 & 3.1 & 19 & 8,000 & 600 & 6.4 & 1,600 & 740 & $<0.6$ & 51 & 4 & 550 & 20 & $<2$ & 1,500 & 61 & 87 & 12 & 49 \\
\hline L-3 & 1.1 & 3,100 & 400 & 2.8 & 930 & 0.68 & 4,000 & 58 & 36 & $<0.3$ & 83 & 34,000 & 410 & 3.7 & 1,000 & 7,000 & 16 & 40 & 17 & 860 & 170 & $<2$ & 2,200 & 70 & $<2$ & 13 & 5,100 \\
\hline $\mathrm{L}-3 \mathrm{~b}$ & 2.9 & 5,200 & 1,400 & 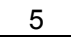 & 900 & 2.3 & 4,200 & 160 & 98 & $<0.3$ & 260 & 59,000 & 330 & 2 & 460 & 23,000 & 3.3 & 61 & 35 & 840 & 550 & $<2$ & 2,200 & 73 & $<2$ & 15 & 9,800 \\
\hline $\mathrm{L}$ & $<0.3$ & 3,700 & 25 & 1.8 & 150 & 0.56 & 4,200 & 14 & 5.6 & 2.3 & 29 & 11,000 & 1,300 & 6.1 & 2,200 & 2,000 & 0.6 & 58 & 6.6 & 980 & 38 & $<2$ & 1,800 & 29 & 310 & 15 & 1,100 \\
\hline L-4a & 35 & 400 & 78 & 2.5 & 200 & 0.41 & 3,400 & 20 & 12 & 0.6 & 23 & 25,000 & 590 & 4.9 & 1,800 & 2,500 & 0.93 & 50 & 6.7 & 940 & 50 & $<2$ & 1,800 & 30 & 140 & 14 & 2,200 \\
\hline L-5 & $<0.3$ & 000 & 14 & 1.2 & 130 & 0.23 & 4,200 & 3.8 & 6.6 & 2.6 & 18 & 11,000 & 1,000 & 6.1 & 2,400 & 1,200 & $<0.6$ & 45 & 5.2 & 1,600 & 30 & $<2$ & 1,700 & 21 & 330 & 16 & 660 \\
\hline L-6 & $<0.3$ & 800 & 7 & 1.6 & 130 & 0.36 & 6,400 & 0.84 & 7.8 & 1.9 & 21 & 10,000 & 980 & 4.1 & 2,100 & 1,400 & 3.6 & 55 & 6.2 & 1,900 & 11 & $<2$ & 1,700 & 35 & 160 & 4 & 7 \\
\hline L-7 & $<0.3$ & 900 & 5.9 & .75 & 65 & $<0.2$ & 3,400 & 2 & 3.5 & 1.8 & 15 & 5,900 & 730 & 3.6 &, 500 & 500 & 0.66 & 39 & 3.5 & 1,200 & 20 & $<2$ & 1,200 & 14 & 180 & 9.9 & 380 \\
\hline L-8 & $<0.3$ & 2,900 & 6.6 & 1. & 110 & 0.41 & 4,400 & 1.1 & 13 & $\leq$ & 34 & 11,000 & 1,400 & 3.3 & 2,000 & 2,000 & 5 & 72 & 8 & 1,400 & 12 & $<2$ & 1,600 & 33 & 220 & 17 & 110 \\
\hline L-9 & $<0.3$ & 700 & 0 & 1.4 & 100 & 0.26 & 5,400 & 3.2 & 7.2 & 3.4 & 22 & 8,800 & 1,200 & 4.6 & 900 & 1,000 & 2.2 & 90 & 6.7 & 200 & 17 & $<2$ & 1,600 & 23 & 260 & 18 & 300 \\
\hline L-100 & 23 & 7,700 & 2,600 & 2 & 420 & 1.9 & 2,800 & 10 & 120 & $<0.3$ & 310 & 29,000 & 370 & 4.2 & 410 & 4,000 & 3.6 & 40 & 30 & 350 & ,200 & $<2$ & 2,000 & 54 & $<2$ & 4.4 & 6,800 \\
\hline & $<0.3$ & 4,800 & 5.1 & 1.2 & 59 & 0.2 & 5,100 & 1.2 & 5.5 & 18 & 15 & 9,200 & 1,400 & 10 & 3,800 & 310 & $<0.6$ & 67 & 11 & 1,600 & 13 & $<2$ & 2,000 & 29 & 700 & 24 & 88 \\
\hline PP-2 & 0.37 & 3,300 & 9.5 & 1.2 & 51 & 0.2 & 5,200 & 1.6 & 3.7 & 7.1 & 19 & 6,700 & 910 & 5.8 & 2,800 & 400 & 0.74 & 72 & 5.4 & 1,200 & 80 & $<2$ & 1,500 & 28 & 350 & 16 & 180 \\
\hline$P-3$ & 9.9 & 200 & 160 & 1.2 & 100 & .36 & 3,100 & 13 & 2.5 & 2.7 & 200 & 1,000 & 650 & 2.6 & 1,400 & 7,900 & 2.2 & 46 & 7.8 & 880 & .000 & 2.1 & 1,300 & 20 & $<2$ & 13 & 500 \\
\hline
\end{tabular}




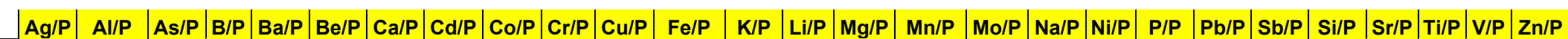

\begin{tabular}{|c|c|c|c|c|c|c|c|c|c|c|c|c|c|c|c|c|c|c|c|c|c|c|c|c|c|c|c|}
\hline Field No. & $\mathrm{pm}$ & $\mathrm{pm}$ & ppm & $\mathrm{ppm}$ & $\mathrm{ppm}$ & om & $\mathrm{ppm}$ & ppm & ppm & $\mathrm{p}$ & ppm & om & $\mathrm{ppm}$ & $\mathrm{ppm}$ & $\mathrm{ppm}$ & $\mathrm{ppm}$ & $\mathrm{om}$ & ppm & $\mathrm{m}$ & ppm & ppm & ppm & $\mathrm{pm}$ & ppm & $\mathrm{m}$ & ppm & $\mathrm{m}$ \\
\hline PP-4 & 3.5 & 3,200 & 72 & 1.7 & 100 & 0.97 & 4,700 & 7.6 & 5 & 3.4 & 84 & 10,000 & 1,300 & 5.8 & 2,500 & 2,600 & 0.87 & 110 & 5.6 & 1,500 & 590 & $<2$ & 1,800 & 34 & 70 & 17 & 1,500 \\
\hline PP- & 1.4 & 500 & 31 & 1.3 & 85 & .36 & 5,700 & 2.8 & 3.3 & 3.3 & 34 & 100 & 1,100 & 4.9 & 000 & 1,500 & 62 & 78 & 4.7 & 2,200 & 210 & $<2$ & 500 & 24 & 50 & 3 & 720 \\
\hline$S-1$ & 0.32 & 900 & 20 & 1.4 & 85 & 32 & 800 & 1.6 & 7.5 & 8.8 & 42 & 10,000 & 1,500 & 8.4 & 4,400 & 720 & $<0.6$ & 75 & 6.8 & 1,100 & 52 & $<2$ & 100 & 31 & 90 & 24 & 120 \\
\hline S-1a & 39 & 6,200 & 450 & 5.2 & 100 & 1.2 & 3,700 & 140 & 95 & $<0.3$ & 4,800 & 59,000 & 1,200 & 3.2 & 960 & 23,000 & 0.6 & 160 & 44 & 900 & 2,600 & 37 & 6,600 & 49 & $<2$ & 12 & 8,700 \\
\hline & 0.3 & 5,900 & 16 & 1.2 & 100 & 0.97 & 6,400 & 1.2 & 4.9 & 11 & 20 & 400 & 1,400 & 5.2 & 3,200 & 420 & $<0.6$ & 81 & 6.4 & 610 & 23 & $<2$ & 700 & 47 & 330 & 13 & 80 \\
\hline S & 2.7 & 2,600 & 270 & 1.7 & 110 & 0.44 & 3,900 & 19 & 8.2 & 3.6 & 120 & 12,000 & 800 & 2.6 & 1,600 & 2,900 & 1.2 & 88 & 11 & 1,100 & 810 & $<2$ & 1,600 & 40 & 27 & 12 & 1,000 \\
\hline & 32 & 400 & 450 & 2.2 & 210 & 74 & 6,200 & 47 & $<0.3$ & 2.4 & 600 & 20,000 & 600 & 2.1 & 1,700 & 20,000 & .0 & 65 & 11 & 860 & 5,400 & 2 & 200 & 60 & $<2$ & 8.4 & 6,600 \\
\hline S-100 & 8.9 & 10,000 & 370 & 2.3 & 120 & 0.95 & 4,300 & 38 & 41 & 7.7 & 2,900 & 27,000 & 1,600 & 9.4 & 3,900 & 9,100 & $<0.6$ & 79 & 16 & 1,200 & 820 & $<2$ & 2,100 & 35 & $<2$ & 23 & 2,000 \\
\hline $\mathrm{S}$ & 3.2 & 300 & 25 & 3.9 & 120 & 0.47 & 8,200 & 3.4 & 12 & 7 & 190 & 16,000 & 2,400 & 7.3 & 4,400 & 560 & 0.6 & 76 & 10 & 1,800 & 210 & $<2$ & 200 & 39 & 390 & 32 & 420 \\
\hline $\mathrm{S}$ & 4 & 000 & 21 & 2.1 & 120 & 1.2 & 5,600 & 31 & 30 & 5.9 & 4,500 & 17,000 & 1,300 & 6.1 & 3,900 & 100 & $=0.6$ & 100 & 21 & 1,400 & 480 & $<2$ & 500 & 61 & $<2$ & 1 & 1,30 \\
\hline WS- & $<0.3$ & 600 & 20 & 1.8 & 65 & 0.26 & 4,800 & 1.2 & 8.3 & 5.5 & 13 & 14,000 & 2,300 & 12 & 4,500 & 500 & $<0.6$ & 60 & 7.1 & 1,100 & 26 & $<2$ & 600 & 24 & 880 & 37 & 82 \\
\hline WS-2 & 1.8 & 5,100 & 1,100 & 2.6 & 130 & 0.81 & 5,600 & 14 & 23 & 2 & 66 & 21,000 & 2,500 & 12 & 4,100 & 5,700 & 1.4 & 78 & 16 & 1,300 & 260 & $<2$ & 2,600 & 38 & 650 & 28 & 2,90 \\
\hline WS-2a & 1.5 & 3,000 & 200 & 1.9 & 82 & 0.64 & 4,000 & 9.3 & 11 & 4 & 61 & 17,000 & 1,300 & 5.4 & 2,200 & 2,300 & 2 & 61 & 8.5 & 980 & 330 & $<2$ & 1,800 & 24 & 320 & 20 & 1,700 \\
\hline WS-3 & 0.77 & 3,100 & 530 & 1.8 & 70 & 0.68 & 3,400 & 9 & 7.6 & 3.2 & 39 & 12,000 & 1,300 & 5.8 & 2,300 & 1,200 & .94 & 50 & 7.4 & 960 & 200 & $<2$ & 1,800 & 16 & 410 & 18 & 1,50 \\
\hline WS- 4 & $<0.3$ & 100 & 4.4 & 1.1 & 74 & 0.55 & 3,200 & 0.73 & 5.5 & 2.1 & 22 & 6,900 & 1,600 & 5.8 & 2,300 & 490 & $<0.6$ & 46 & 4.6 & 800 & 17 & $<2$ & 1,600 & 15 & 440 & 14 & 16 \\
\hline WS-5 & $<0.3$ & 100 & 5.9 & 1.4 & 77 & 0.2 & 5,000 & 0.78 & 5.2 & 4.4 & 13 & 900 & 1,300 & 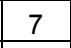 & 2,900 & 24 & 0.6 & 87 & 4.7 & 1,400 & 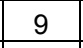 & 2 & 1,700 & 29 & 490 & 6 & 35 \\
\hline WS-7 & 1.1 & 300 & 74 & 1.2 & 77 & 0.33 & 4,000 & 2.3 & 5.3 & 3.2 & 19 & 00 & 1,500 & 6.4 & 2,700 & $4 \varepsilon$ & $<0.6$ & 60 & 4.9 & 1,200 & 41 & $<2$ & 1,700 & 19 & 520 & 1 & 360 \\
\hline WS- 100 & $<0.3$ & 5,500 & 26 & 1.9 & 80 & 0.33 & 5,000 & 1.7 & 8.6 & 5.9 & 22 & 14,000 & 2,200 & 10 & 4,300 & 640 & 0.65 & 54 & 7.8 & 1,200 & 48 & $<2$ & 2,400 & 24 & 780 & 35 & 110 \\
\hline WS-101 & $<0.3$ & 4,800 & 8.2 & 1.8 & 63 & 0.23 & 4,400 & 0.95 & 6.8 & 4.2 & 12 & 11,000 & 1,900 & 12 & 3,600 & 440 & $<0.6$ & 52 & 5.6 & 1,000 & 27 & $<2$ & 2,200 & 24 & 770 & 28 & \\
\hline WS-102 & 2.2 & 5,000 & 1,700 & 3 & 120 & 1 & 5,400 & 20 & 29 & 1.9 & 83 & 26,000 & 2,400 & 11 & 3,700 & 8100 & 1.8 & 85 & 21 & 1,300 & 380 & $<2$ & 2,800 & 43 & 570 & 26 & 4,700 \\
\hline WS-103a & 3 & 800 & 1,800 & 1.5 & 32 & 0.33 & 1,200 & 3 & 3.3 & 2 & 67 & 15,000 & 400 & 0.92 & 430 & 300 & 2.7 & 21 & 2.1 & 620 & 690 & $<2$ & 860 & 3 & 74 & 6.7 & 250 \\
\hline$S-103 b$ & 2.5 & 700 & 2,800 & 3 & 82 & 0.93 & 3,600 & 16 & 19 & 4.1 & 150 & 25,000 & 1,300 & 5.5 & 2,100 & 2,200 & 2.5 & 53 & 8.4 & 920 & 480 & $<2$ & 1,900 & 28 & 280 & 24 & 1,400 \\
\hline
\end{tabular}


Appendix 9. Mercury in water, filtered and unfiltered samples by CV-FAAS from upper Prickly Pear Creek watershed.

[Samples collected by Terry Klein, USGS, in October 2000 and analyzed by James Crock, USGS. Detection limit is $0.005 \mu \mathrm{g} / 1$ ]

\begin{tabular}{|c|c|c|c|c|c|}
\hline $\begin{array}{l}\text { Field } \\
\text { Number }\end{array}$ & Sample Type & $\mathrm{Hg}, \mathrm{ppb}$ & Field Number & Sample Type & $\mathrm{Hg}, \mu \mathrm{g} / \mathrm{l}$ \\
\hline$L-3 b-F$ & water, filtered & 0.006 & WS-3-F & water, filtered & $<0.005$ \\
\hline$L-3 b-U$ & water, unfiltered & $<0.005$ & WS-3-U & water, unfiltered & $<0.005$ \\
\hline $\mathrm{L}-2-\mathrm{F}$ & water, filtered & $<0.005$ & WS-2a-U & water, unfiltered & $<0.005$ \\
\hline L-2-U & water, unfiltered & $<0.005$ & WS-2a-F & water, filtered & $<0.005$ \\
\hline L-9-U & water, unfiltered & $<0.005$ & WS-2-U & water, unfiltered & $<0.005$ \\
\hline L-9-F & water, filtered & $<0.005$ & WS-2-F & water, filtered & $<0.005$ \\
\hline$S-1 a-U$ & water, unfiltered & 0.005 & $B L-1000$ & blank water, filtered & $<0.005$ \\
\hline S-1a-F & water, filtered & $<0.005$ & BL-000 & Blank water, unfiltered & $<0.005$ \\
\hline$S-4-F$ & water, filtered & $<0.005$ & BL-1002 & blank water, filtered & $<0.005$ \\
\hline S-4-U & water, unfiltered & 0.005 & & & \\
\hline$B-1-U$ & water, unfiltered & 0.005 & & & \\
\hline B-1-F & water, filtered & $<0.005$ & & & \\
\hline C-100-F & water, filtered & $<0.005$ & & & \\
\hline C-100-U & water, unfiltered & $<0.005$ & & & \\
\hline C-101-U & water, unfiltered & $<0.005$ & & & \\
\hline C-101-F & water, filtered & $<0.005$ & & & \\
\hline PP-4-U & water, unfiltered & $<0.005$ & & & \\
\hline PP-4-F & water, filtered & $<0.005$ & & & \\
\hline C-104-U & water, unfiltered & $<0.005$ & & & \\
\hline C-104-F & water, filtered & $<0.005$ & & & \\
\hline C-6-U & water, unfiltered & $<0.005$ & & & \\
\hline C-6-F & water, filtered & $<0.005$ & & & \\
\hline PP-2-U & water, unfiltered & $<0.005$ & & & \\
\hline PP-2-F & water, filtered & $<0.005$ & & & \\
\hline L-100-F & water, filtered & $<0.005$ & & & \\
\hline L-100-U & water, unfiltered & $<0.005$ & & & \\
\hline WS-7-U & water, unfiltered & $<0.005$ & & & \\
\hline WS-7-F & water, filtered & $<0.005$ & & & \\
\hline
\end{tabular}


Appendix 10. Provisional biology data from streams in the upper Prickly Pear Creek watershed, Montana, 2000. All measurements are as $\mu \mathrm{g} / \mathrm{g}$ dry weight. BIO=biofilm, FIL=filet, INV=benthic macroinvertebrates, $\mathrm{PC}=$ pyloric caeca, $\mathrm{WF}=$ Whole Fish.

Aquatic Vegetation, Biofilm, and Benthic Macroinvertebrates

\begin{tabular}{|c|c|c|c|c|c|c|c|c|}
\hline Site ID & Date & Sample ID & Type & $\mu \mathrm{g}$ As $/ \mathrm{g}$ & $\mu \mathrm{g} \mathrm{Cd} / \mathrm{g}$ & $\mu \mathrm{g} \mathrm{Cu} / \mathrm{g}$ & $\mu \mathrm{g} \mathrm{Pb} / \mathrm{g}$ & $\mu \mathrm{g} \mathrm{zn} / \mathrm{g}$ \\
\hline WS3 & $10 / 2 / 00$ & WS3-INV-1 & INV & 35.16 & 3.63 & 44.82 & 21.70 & 0.67 \\
\hline wS3 & $10 / 2 / 00$ & WS3-INV-2 & INV & 53.64 & 4.24 & 38.40 & 27.10 & 0.68 \\
\hline wS3 & $10 / 2 / 00$ & WS3-INV-3 & INV & 79.46 & 7.38 & 40.16 & 38.00 & 0.71 \\
\hline WS3 & $10 / 2 / 00$ & WS3-INV-4 & INV & 34.80 & 4.33 & 49.80 & 18.90 & 0.65 \\
\hline WS3 & $10 / 2 / 00$ & No Biofilm & $\mathrm{BIO}$ & & & & & \\
\hline WS3 & $10 / 2 / 00$ & No Biofilm & $\mathrm{BIO}$ & & & & & \\
\hline WS3 & $10 / 2 / 00$ & No Biofilm & $\mathrm{BIO}$ & & & & & \\
\hline WS3 & $10 / 2 / 00$ & No Biofilm & $\mathrm{BIO}$ & & & & & \\
\hline WS3 & $10 / 5 / 00$ & No Plants & $\mathrm{PL}$ & & & & & \\
\hline WS3 & $10 / 5 / 00$ & No Plants & $\mathrm{PL}$ & & & & & \\
\hline WS3 & $10 / 5 / 00$ & No Plants & PL & & & & & \\
\hline WS3 & $10 / 5 / 00$ & No Plants & $\mathrm{PL}$ & & & & & \\
\hline PP1 & $10 / 5 / 00$ & PP1-INV-1 & INV & 2.36 & 1.23 & 15.12 & 2.18 & 0.22 \\
\hline PP1 & $10 / 5 / 00$ & PP1-INV-2 & INV & 0.31 & 1.19 & 17.08 & 1.29 & 0.19 \\
\hline PP1 & $10 / 5 / 00$ & PP1-INV-3 & INV & -1.05 & 1.15 & 18.92 & 1.20 & 0.20 \\
\hline PP1 & $10 / 5 / 00$ & PP1-INV-4 & INV & -0.73 & 1.05 & 20.59 & 0.97 & 0.19 \\
\hline PP1 & $10 / 5 / 00$ & No Biofilm & $\mathrm{BIO}$ & & & & & \\
\hline PP1 & $10 / 5 / 00$ & No Biofilm & $\mathrm{BIO}$ & & & & & \\
\hline PP1 & $10 / 5 / 00$ & No Biofilm & $\mathrm{BIO}$ & & & & & \\
\hline PP1 & $10 / 5 / 00$ & No Biofilm & $\mathrm{BIO}$ & & & & & \\
\hline PP1 & $10 / 5 / 00$ & PP1-PL-1 & $\mathrm{PL}$ & 3.11 & 1.24 & 9.89 & 7.14 & 0.06 \\
\hline PP1 & $10 / 5 / 00$ & PP1-PL-2 & $\mathrm{PL}$ & 6.17 & 1.38 & 16.75 & 10.67 & 0.11 \\
\hline PP1 & $10 / 5 / 00$ & PP1-PL-3 & $\mathrm{PL}$ & 4.03 & 1.82 & 13.65 & 9.16 & 0.07 \\
\hline PP1 & $10 / 5 / 00$ & PP1-PL-4 & $\mathrm{PL}$ & 2.93 & 0.82 & 11.52 & 8.03 & 0.06 \\
\hline PP3 & $10 / 3 / 00$ & PP3-INV-1 & INV & 27.49 & 7.98 & 119.76 & 281.00 & 1.65 \\
\hline PP3 & $10 / 3 / 00$ & PP3-INV-2 & INV & 13.21 & 7.06 & 85.52 & 157.00 & 1.18 \\
\hline PP3 & $10 / 3 / 00$ & PP3-INV-3 & INV & 56.38 & 10.5 & 181.85 & 493.00 & 2.47 \\
\hline PP3 & $10 / 3 / 00$ & PP3-INV-4 & INV & 10.94 & 12.4 & 50.40 & 109.00 & 0.99 \\
\hline PP3 & $10 / 3 / 00$ & No Biofilm & $\mathrm{BIO}$ & & & & & \\
\hline PP3 & $10 / 3 / 00$ & No Biofilm & $\mathrm{BIO}$ & & & & & \\
\hline PP3 & $10 / 3 / 00$ & No Biofilm & $\mathrm{BIO}$ & & & & & \\
\hline PP3 & $10 / 3 / 00$ & No Biofilm & $\mathrm{BIO}$ & & & & & \\
\hline PP3 & $10 / 3 / 00$ & PP3-PL-1 & $\mathrm{PL}$ & 136.75 & 27.70 & 255.81 & 761.25 & 3.95 \\
\hline PP3 & $10 / 3 / 00$ & PP3-PL-2 & $\mathrm{PL}$ & 82.10 & 21.50 & 223.66 & 727.33 & 3.35 \\
\hline PP3 & $10 / 3 / 00$ & PP3-PL-3 & $\mathrm{PL}$ & 110.76 & 22.40 & 184.53 & 733.42 & 2.71 \\
\hline PP3 & $10 / 3 / 00$ & PP3-PL-4 & $\mathrm{PL}$ & 65.86 & 27.50 & 145.72 & 563.28 & 3.31 \\
\hline PP5 & $10 / 6 / 00$ & PP5-INV-1 & INV & 7.42 & 1.63 & 38.49 & 34.70 & 0.65 \\
\hline PP5 & $10 / 6 / 00$ & PP5-INV-2 & INV & 7.74 & 2.27 & 43.63 & 41.80 & 0.79 \\
\hline PP5 & $10 / 6 / 00$ & PP5-INV-3 & INV & 7.61 & 1.98 & 39.30 & 54.60 & 0.64 \\
\hline PP5 & $10 / 6 / 00$ & PP5-INV-4 & INV & 10.68 & 1.98 & 51.68 & 54.80 & 0.81 \\
\hline PP5 & $10 / 6 / 00$ & PP5-INV-5 & INV & & & & & \\
\hline PP5 & $10 / 6 / 00$ & PP5-INV-6 & INV & 11.58 & 2.31 & 44.66 & 62.50 & 0.73 \\
\hline PP5 & $10 / 6 / 00$ & PP5-INV-7 & INV & 8.45 & 1.71 & 42.19 & 39.80 & 0.73 \\
\hline PP5 & $10 / 6 / 00$ & PP5-INV-8 & INV & 13.18 & 2.23 & 55.75 & 56.60 & 0.81 \\
\hline PP5 & $10 / 6 / 00$ & No Biofilm & $\mathrm{BIO}$ & & & & & \\
\hline PP5 & $10 / 6 / 00$ & No Biofilm & $\mathrm{BIO}$ & & & & & \\
\hline PP5 & $10 / 6 / 00$ & No Biofilm & $\mathrm{BIO}$ & & & & & \\
\hline PP5 & $10 / 6 / 00$ & No Biofilm & $\mathrm{BIO}$ & & & & & \\
\hline PP5 & $10 / 6 / 00$ & PP5-PL-1 & $\mathrm{PL}$ & 38.37 & 10.6 & 40.16 & 169.45 & 3.07 \\
\hline PP5 & $10 / 6 / 00$ & PP5-PL-2 & $\mathrm{PL}$ & 62.75 & 26.6 & 85.92 & 279.79 & 6.22 \\
\hline PP5 & $10 / 6 / 00$ & PP5-PL-3 & $\mathrm{PL}$ & 55.78 & 14.8 & 84.54 & 254.00 & 5.93 \\
\hline
\end{tabular}




\begin{tabular}{|c|c|c|c|c|c|c|c|c|}
\hline Site ID & Date & Sample ID & Type & mg As & $\mathrm{mg} \mathrm{Cd}$ & $\mathrm{mg} \mathrm{Cu}$ & $\mathrm{mg} \mathrm{Pb}$ & $\mathrm{mg} \mathrm{Zn}$ \\
\hline PP5 & $10 / 6 / 00$ & PP5-PL-4 & $\mathrm{PL}$ & 49.18 & 17.7 & 63.08 & 197.78 & 5.41 \\
\hline C5 & $10 / 5 / 00$ & C5-INV-1 & INV & 12.79 & 2.81 & 36.67 & 16.80 & 0.34 \\
\hline C5 & $10 / 5 / 00$ & C5-INV-2 & INV & 14.71 & 5.53 & 42.94 & 37.20 & 0.64 \\
\hline C5 & $10 / 5 / 00$ & C5-INV-3 & INV & 13.75 & 2.93 & 32.21 & 15.40 & 0.36 \\
\hline $\mathrm{C} 5$ & $10 / 5 / 00$ & C5-INV-4 & INV & 19.73 & 3.03 & 36.53 & 25.30 & 0.43 \\
\hline $\mathrm{C} 5$ & $10 / 5 / 00$ & No Biofilm & $\mathrm{BIO}$ & & & & & \\
\hline C5 & $10 / 5 / 00$ & No Biofilm & $\mathrm{BIO}$ & & & & & \\
\hline C5 & $10 / 5 / 00$ & No Biofilm & $\mathrm{BIO}$ & & & & & \\
\hline $\mathrm{C} 5$ & $10 / 5 / 00$ & No Biofilm & $\mathrm{BIO}$ & & & & & \\
\hline C5 & $10 / 5 / 00$ & C5-PL-1 & $\mathrm{PL}$ & 115.75 & 7.62 & 49.23 & 133.32 & 1.20 \\
\hline C5 & $10 / 5 / 00$ & C5-PL-2 & $\mathrm{PL}$ & 255.45 & 14.8 & 81.50 & 210.73 & 2.05 \\
\hline C5 & $10 / 5 / 00$ & C5-PL-3 & $\mathrm{PL}$ & 195.47 & 16.1 & 78.65 & 188.19 & 2.55 \\
\hline $\mathrm{C} 5$ & $10 / 5 / 00$ & C5-PL-4 & $\mathrm{PL}$ & 169.19 & 17.9 & 74.02 & 174.23 & 2.63 \\
\hline L5 & $10 / 6 / 00$ & L5-INV-1 & INV & 0.89 & 1.49 & 29.78 & 2.11 & 0.62 \\
\hline L5 & $10 / 6 / 00$ & L5-INV-2 & INV & 4.40 & 2.85 & 35.75 & 3.56 & 1.07 \\
\hline L5 & $10 / 6 / 00$ & L5-INV-3 & INV & 1.38 & 7.74 & 32.52 & 1.53 & 0.88 \\
\hline L5 & $10 / 6 / 00$ & L5-INV-4 & INV & 4.31 & 5.14 & 29.49 & 3.64 & 0.93 \\
\hline L5 & $10 / 6 / 00$ & No Biofilm & $\mathrm{BIO}$ & & & & & \\
\hline L5 & $10 / 6 / 00$ & No Biofilm & $\mathrm{BIO}$ & & & & & \\
\hline L5 & $10 / 6 / 00$ & No Biofilm & $\mathrm{BIO}$ & & & & & \\
\hline L5 & $10 / 6 / 00$ & No Biofilm & $\mathrm{BIO}$ & & & & & \\
\hline L5 & $10 / 6 / 00$ & L5-PL-1 & $\mathrm{PL}$ & 17.19 & 5.34 & 20.54 & 13.42 & 1.57 \\
\hline L5 & $10 / 6 / 00$ & L5-PL-2 & $\mathrm{PL}$ & 13.81 & 2.95 & 15.47 & 15.38 & 0.95 \\
\hline L5 & $10 / 6 / 00$ & L5-PL-3 & $\mathrm{PL}$ & 31.81 & 8.6 & 26.74 & 18.53 & 2.09 \\
\hline L5 & $10 / 6 / 00$ & L5-PL-4 & $\mathrm{PL}$ & 21.63 & 5.2 & 20.15 & 11.94 & 1.70 \\
\hline L5 & $10 / 6 / 00$ & L5-PL-5 & $\mathrm{PL}$ & & & & & \\
\hline L5 & $10 / 6 / 00$ & L5-PL-6 & $\mathrm{PL}$ & 27.58 & 5.07 & 24.18 & 18.65 & 1.66 \\
\hline L5 & $10 / 6 / 00$ & L5-PL-7 & $\mathrm{PL}$ & 16.32 & 2.92 & 15.27 & 14.29 & 0.80 \\
\hline L5 & $10 / 6 / 00$ & L5-PL-8 & $\mathrm{PL}$ & 20.45 & 4.86 & 20.94 & 12.55 & 1.71 \\
\hline L5 & $10 / 6 / 00$ & L5-PL-9 & $\mathrm{PL}$ & 18.82 & 5.55 & 20.43 & 12.10 & 1.73 \\
\hline L5 & $10 / 6 / 00$ & L5-PL-10 & $\mathrm{PL}$ & & & & & \\
\hline WS7 & $10 / 3 / 00$ & WS7-INV-1 & INV & 9.46 & 1.95 & 38.32 & 16.50 & 0.38 \\
\hline WS7 & $10 / 3 / 00$ & WS7-INV-2 & INV & 17.24 & 2.43 & 38.17 & 11.30 & 0.37 \\
\hline WS7 & $10 / 3 / 00$ & WS7-INV-3 & INV & 10.70 & 1.72 & 42.63 & 7.31 & 0.37 \\
\hline WS7 & $10 / 3 / 00$ & WS7-INV-4 & INV & 8.18 & 1.25 & 32.93 & 4.58 & 0.38 \\
\hline WS7 & $10 / 3 / 00$ & WS7-BIO-1 & $\mathrm{BIO}$ & 75.55 & 1.12 & 12.92 & 35.07 & 0.29 \\
\hline WS7 & $10 / 3 / 00$ & WS7-BIO-2 & $\mathrm{BIO}$ & 248.14 & 1.01 & 8.74 & 24.86 & 0.20 \\
\hline WS7 & $10 / 3 / 00$ & WS7-BIO-3 & $\mathrm{BIO}$ & 30.36 & 1.07 & 7.69 & 18.52 & 0.14 \\
\hline WS7 & $10 / 3 / 00$ & WS7-BIO-4 & $\mathrm{BIO}$ & 48.56 & 1.2 & 8.97 & 22.45 & 0.21 \\
\hline WS7 & $10 / 5 / 00$ & WS7-PL-1 & $\mathrm{PL}$ & 207.42 & 3.24 & 34.01 & 100.16 & 0.54 \\
\hline WS7 & $10 / 5 / 00$ & WS7-PL-2 & $\mathrm{PL}$ & 103.03 & 4.03 & 21.11 & 45.62 & 0.78 \\
\hline WS7 & $10 / 5 / 00$ & WS7-PL-3 & $\mathrm{PL}$ & 107.98 & 2.96 & 20.64 & 41.76 & 0.74 \\
\hline WS7 & $10 / 5 / 00$ & WS7-PL-4 & $\mathrm{PL}$ & 106.48 & 3.41 & 22.96 & 47.19 & 0.81 \\
\hline PP4 & $10 / 3 / 00$ & PP4-INV-1 & INV & 8.63 & 3.13 & 29.52 & 35.80 & 0.63 \\
\hline PP4 & $10 / 3 / 00$ & PP4-INV-2 & INV & 13.47 & 3.07 & 39.81 & 34.60 & 0.76 \\
\hline PP4 & $10 / 3 / 00$ & PP4-INV-3 & INV & 11.47 & 3.53 & 41.77 & 37.60 & 0.73 \\
\hline PP4 & $10 / 3 / 00$ & PP4-INV-4 & INV & 15.68 & 3 & 47.55 & 61.40 & 0.78 \\
\hline PP4 & $10 / 3 / 00$ & PP4-BIO-1 & $\mathrm{BIO}$ & 53.37 & 16.2 & 109.00 & 368.00 & 4.18 \\
\hline PP4 & $10 / 3 / 00$ & PP4-BIO-2 & $\mathrm{BIO}$ & 53.78 & 22.6 & 128.00 & 414.00 & 3.64 \\
\hline PP4 & $10 / 3 / 00$ & PP4-BIO-3 & $\mathrm{BIO}$ & 65.27 & 17.3 & 134.00 & 396.00 & 3.82 \\
\hline PP4 & $10 / 3 / 00$ & PP4-BIO-4 & $\mathrm{BIO}$ & 58.40 & 15.1 & 120.00 & 381.00 & 3.45 \\
\hline
\end{tabular}




\begin{tabular}{|c|c|c|c|c|c|c|c|c|}
\hline Site ID & Date & Sample ID & Type & $\mu \mathrm{g}$ As & $\mu \mathrm{g} \mathrm{Cd}$ & $\mu \mathrm{g} \mathrm{Cu}$ & $\mu \mathrm{g} \mathrm{Pb}$ & $\mu \mathrm{g} \mathrm{Zn}$ \\
\hline $\begin{array}{l}\text { PP4 } \\
\text { PP4 } \\
\text { PP4 } \\
\text { PP4 } \\
\end{array}$ & $\begin{array}{l}10 / 3 / 00 \\
10 / 3 / 00 \\
10 / 3 / 00 \\
10 / 3 / 00 \\
\end{array}$ & $\begin{array}{l}\text { No Plants } \\
\text { No Plants } \\
\text { No Plants } \\
\text { No Plants }\end{array}$ & $\begin{array}{l}\text { PL } \\
\text { PL } \\
\text { PL } \\
\text { PL }\end{array}$ & & & & & \\
\hline WS2 & $10 / 3 / 00$ & WS2-INV-1 & INV & 94.78 & 6 & 34.92 & 18.80 & 0.99 \\
\hline WS2 & $10 / 3 / 00$ & WS2-INV-2 & INV & 107.26 & 5.72 & 31.61 & 17.90 & 0.92 \\
\hline WS2 & $10 / 3 / 00$ & WS2-INV-3 & INV & 244.84 & 5.79 & 33.53 & 37.10 & 0.99 \\
\hline WS2 & $10 / 3 / 00$ & WS2-INV-4 & INV & 157.70 & 4.72 & 35.12 & 24.20 & 1.00 \\
\hline WS2 & $10 / 3 / 00$ & No Biofilm & $\mathrm{BIO}$ & & & & & \\
\hline WS2 & $10 / 3 / 00$ & No Biofilm & $\mathrm{BIO}$ & & & & & \\
\hline WS2 & $10 / 3 / 00$ & No Biofilm & $\mathrm{BIO}$ & & & & & \\
\hline WS2 & $10 / 3 / 00$ & No Biofilm & $\mathrm{BIO}$ & & & & & \\
\hline WS2 & $10 / 3 / 00$ & No Plants & PL & & & & & \\
\hline WS2 & $10 / 3 / 00$ & No Plants & PL & & & & & \\
\hline WS2 & $10 / 3 / 00$ & No Plants & PL & & & & & \\
\hline WS2 & $10 / 3 / 00$ & No Plants & PL & & & & & \\
\hline L8 & $10 / 4 / 00$ & L8-INV-1 & INV & 4.28 & 3.74 & 22.91 & 3.52 & 0.27 \\
\hline L8 & $10 / 4 / 00$ & L8-INV-2 & INV & 2.31 & 3.46 & 22.33 & 3.42 & 0.24 \\
\hline L8 & $10 / 4 / 00$ & No sample & INV & & & & & \\
\hline L8 & $10 / 4 / 00$ & No sample & INV & & & & & \\
\hline L8 & $10 / 4 / 00$ & No Biofilm & $\mathrm{BIO}$ & & & & & \\
\hline L8 & $10 / 4 / 00$ & No Biofilm & $\mathrm{BIO}$ & & & & & \\
\hline L8 & $10 / 4 / 00$ & No Biofilm & $\mathrm{BIO}$ & & & & & \\
\hline L8 & $10 / 4 / 00$ & No Biofilm & $\mathrm{BIO}$ & & & & & \\
\hline L8 & $10 / 4 / 00$ & No Plants & PL & & & & & \\
\hline L8 & $10 / 4 / 00$ & No Plants & PL & & & & & \\
\hline L8 & $10 / 4 / 00$ & No Plants & PL & & & & & \\
\hline L8 & $10 / 4 / 00$ & No Plants & $P \mathrm{PL}$ & & & & & \\
\hline L7 & $10 / 4 / 00$ & L7-INV-1 & INV & 1.61 & 3.89 & 32.41 & 1.45 & 0.47 \\
\hline L7 & $10 / 4 / 00$ & L7-INV-2 & INV & 3.37 & 9.07 & 31.12 & 1.46 & 0.55 \\
\hline L7 & $10 / 4 / 00$ & L7-INV-3 & INV & 2.55 & 6.68 & 30.69 & 1.32 & 0.58 \\
\hline $\mathrm{L} 7$ & $10 / 4 / 00$ & L7-INV-4 & INV & 1.42 & 3.21 & 33.33 & 1.16 & 0.56 \\
\hline L7 & $10 / 4 / 00$ & No Biofilm & $\mathrm{BIO}$ & & & & & \\
\hline L7 & $10 / 4 / 00$ & No Biofilm & $\mathrm{BIO}$ & & & & & \\
\hline L7 & $10 / 4 / 00$ & No Biofilm & $\mathrm{BIO}$ & & & & & \\
\hline $\mathrm{L} 7$ & $10 / 4 / 00$ & No Biofilm & $\mathrm{BIO}$ & & & & & \\
\hline L7 & $10 / 5 / 00$ & L7-PL-1 & $\mathrm{PL}$ & 9.01 & 2.66 & 22.73 & 13.52 & 0.96 \\
\hline L7 & $10 / 5 / 00$ & L7-PL-2 & $\mathrm{PL}$ & 4.32 & 2 & 15.67 & 7.52 & 0.78 \\
\hline L7 & $10 / 5 / 00$ & L7-PL-3 & $\mathrm{PL}$ & 7.90 & 2.02 & 19.32 & 12.24 & 0.82 \\
\hline$\underline{\mathrm{L} 7}$ & $10 / 5 / 00$ & L7-PL-4 & $\mathrm{PL}$ & 9.96 & 2.32 & 20.42 & 10.71 & 0.81 \\
\hline L3W & $10 / 4 / 00$ & L3W-INV-1 & INV & 25.32 & 6.51 & 31.94 & 29.60 & 0.88 \\
\hline L3W & $10 / 4 / 00$ & L3W-INV-2 & INV & 5.59 & 5.89 & 21.74 & 7.51 & 0.70 \\
\hline L3W & $10 / 4 / 00$ & L3W-INV-3 & INV & 3.37 & 39.1 & 21.19 & 4.98 & 0.45 \\
\hline L3W & $10 / 4 / 00$ & L3W-INV-4 & INV & 7.07 & 3.83 & 21.39 & 6.04 & 0.72 \\
\hline L3W & $10 / 4 / 00$ & No Biofilm & $\mathrm{BIO}$ & & & & & \\
\hline L3W & $10 / 4 / 00$ & No Biofilm & $\mathrm{BIO}$ & & & & & \\
\hline L3W & $10 / 4 / 00$ & No Biofilm & $\mathrm{BIO}$ & & & & & \\
\hline L3W & $10 / 4 / 00$ & No Biofilm & $\mathrm{BIO}$ & & & & & \\
\hline L3W & $10 / 5 / 00$ & L3W-PL-1 & $\mathrm{PL}$ & 59.09 & 27.4 & 20.03 & 45.32 & 3.30 \\
\hline L3W & $10 / 5 / 00$ & L3W-PL-2 & $\mathrm{PL}$ & 78.51 & 22.9 & 18.10 & 59.52 & 3.61 \\
\hline L3W & $10 / 5 / 00$ & L3W-PL-3 & $\mathrm{PL}$ & 31.84 & 12.7 & 14.45 & 29.86 & 1.66 \\
\hline L3W & $10 / 5 / 00$ & L3W-PL-4 & $\mathrm{PL}$ & 76.28 & 22.5 & 21.93 & 65.95 & 3.11 \\
\hline \multirow{2}{*}{$\begin{array}{l}\text { L3E } \\
\text { L3E }\end{array}$} & \multirow{2}{*}{$\begin{array}{l}10 / 4 / 00 \\
10 / 4 / 00\end{array}$} & L3E-INV-1 & INV & 302.43 & 119 & 148.42 & 139.00 & 4.48 \\
\hline & & No inverts & INV & & & & & \\
\hline
\end{tabular}




\begin{tabular}{|c|c|c|c|c|c|c|c|c|}
\hline Site ID & Date & Sample ID & Type & $\mu \mathrm{g}$ As & $\mu \mathrm{g} \mathrm{Cd}$ & $\mu \mathrm{g} \mathrm{Cu}$ & $\mu \mathrm{g} \quad \mathrm{Pb}$ & $\mu \mathrm{g} \mathrm{Zn}$ \\
\hline L3E & $10 / 4 / 00$ & No inverts & INV & & & & & \\
\hline L3E & $10 / 4 / 00$ & No inverts & INV & & & & & \\
\hline L3E & $10 / 4 / 00$ & No Biofilm & $\mathrm{BIO}$ & & & & & \\
\hline L3E & $10 / 4 / 00$ & No Biofilm & $\mathrm{BIO}$ & & & & & \\
\hline L3E & $10 / 4 / 00$ & No Biofilm & $\mathrm{BIO}$ & & & & & \\
\hline L3E & $10 / 4 / 00$ & No Biofilm & $\mathrm{BIO}$ & & & & & \\
\hline L3E & $10 / 5 / 00$ & L3E-PL-1 & $\mathrm{PL}$ & $1,232.02$ & 268 & 204.24 & 450.25 & 34.01 \\
\hline L3E & $10 / 5 / 00$ & L3E-PL-2 & PL & $1,797.37$ & 243 & 242.40 & 614.56 & 31.60 \\
\hline L3E & $10 / 5 / 00$ & L3E-PL-3 & $\mathrm{PL}$ & $1,116.76$ & 167 & 172.52 & 352.76 & 20.39 \\
\hline L3E & $10 / 5 / 00$ & L3E-PL-4 & $\mathrm{PL}$ & $1,124.29$ & 173 & 166.64 & 316.28 & 25.15 \\
\hline L3C & $10 / 26 / 00$ & L3C-INV-1 & INV & 21.99 & 26 & 33.20 & 14.50 & 2.43 \\
\hline L3C & $10 / 26 / 00$ & L3C-INV-2 & INV & 32.87 & 21.3 & 35.82 & 23.70 & 3.05 \\
\hline L3C & $10 / 26 / 00$ & No inverts & INV & & & & & \\
\hline L3C & $10 / 26 / 00$ & No inverts & INV & & & & & \\
\hline L3C & $10 / 26 / 00$ & No Biofilm & $\mathrm{BIO}$ & & & & & \\
\hline L3C & $10 / 26 / 00$ & No Biofilm & $\mathrm{BIO}$ & & & & & \\
\hline L3C & $10 / 26 / 00$ & No Biofilm & $\mathrm{BIO}$ & & & & & \\
\hline $\mathrm{L} 3 \mathrm{C}$ & $10 / 26 / 00$ & No Biofilm & $\mathrm{BIO}$ & & & & & \\
\hline L3C & $10 / 26 / 00$ & L3C-PL-1 & $\mathrm{PL}$ & 111.35 & 47.9 & 50.45 & 72.08 & 10.10 \\
\hline L3C & $10 / 26 / 00$ & L3C-PL-2 & $\mathrm{PL}$ & 95.89 & 46.9 & 49.88 & 56.34 & 10.10 \\
\hline L3C & $10 / 26 / 00$ & L3C-PL-3 & $\mathrm{PL}$ & 96.79 & 44.7 & 45.92 & 58.70 & 9.76 \\
\hline L3C & $10 / 26 / 00$ & L3C-PL-4 & $\mathrm{PL}$ & 125.00 & 54.6 & 52.27 & 68.66 & 10.89 \\
\hline
\end{tabular}


Individual Tissues

\begin{tabular}{|c|c|c|c|c|c|c|c|c|c|c|c|c|}
\hline Site ID & Date & Species & Sex & $\mathrm{L}(\mathrm{cm})$ & wt (gm) & Type & New Id & $\mu \mathrm{g} \mathrm{As/g}$ & $\mu \mathrm{g} \mathrm{Cd} / \mathrm{g}$ & $\mu \mathrm{g} \mathrm{Cu} / \mathrm{g}$ & $\mu \mathrm{g} \quad \mathrm{Pb} / \mathrm{g}$ & $\mu \mathrm{g} \mathrm{Zn} / \mathrm{g}$ \\
\hline WS3 & $10 / 19 / 00$ & Brook & $M$ & 14 & 23 & Gill & & & & & & \\
\hline WS3 & $10 / 19 / 00$ & Brook & M & 15 & 26 & Gill & PP-WS3-B1G & 0.80 & 11.3 & 3.27 & 0.86 & 0.43 \\
\hline WS3 & $10 / 19 / 00$ & Brook & M & 15 & 26 & Gill & & & & & & \\
\hline WS3 & $10 / 19 / 00$ & Brook & - & 11.5 & 9 & Gill & & & & & & \\
\hline WS3 & $10 / 19 / 00$ & Brook & - & 11.5 & 12 & Gill & & & & & & \\
\hline WS3 & $10 / 19 / 00$ & Brook & $\mathrm{F}$ & 13 & 17 & Gill & PP-WS3-B2G & 4.59 & 11.7 & 3.16 & 1.33 & 0.45 \\
\hline WS3 & $10 / 19 / 00$ & Brook & $M$ & 18.5 & 43 & Gill & & & & & & \\
\hline WS3 & $10 / 19 / 00$ & Brook & $F$ & 12 & 13 & Gill & & & & & & \\
\hline WS3 & $10 / 19 / 00$ & Brook & - & 13 & 18 & Gill & & & & & & \\
\hline WS3 & $10 / 19 / 00$ & Brook & M & 13.5 & 20 & Gill & PP-WS3-B3G & 5.38 & 12.5 & 2.85 & 0.98 & 0.55 \\
\hline WS3 & $10 / 19 / 00$ & Brook & $M$ & 14.5 & 24 & Gill & & & & & & \\
\hline WS3 & $10 / 19 / 00$ & Brook & $F$ & 13 & 17 & Gill & & & & & & \\
\hline WS3 & $10 / 19 / 00$ & Brook & $\mathrm{F}$ & 13 & 18 & Gill & & & & & & \\
\hline WS3 & $10 / 19 / 00$ & Brook & $\mathrm{F}$ & 13.5 & 21 & Gill & PP-WS3-B4G & 4.81 & 12 & 3.13 & 5.49 & 0.50 \\
\hline WS3 & $10 / 19 / 00$ & Brook & $\mathrm{F}$ & 15 & 24 & Gill & & & & & & \\
\hline WS3 & $10 / 19 / 00$ & Brook & $M$ & 14 & 23 & Liver & & & & & & \\
\hline WS3 & $10 / 19 / 00$ & Brook & M & 15 & 26 & Liver & PP-WS3-B1L & 0.73 & 12.4 & 191.78 & 1.25 & 0.34 \\
\hline WS3 & $10 / 19 / 00$ & Brook & M & 15 & 26 & Liver & & & & & & \\
\hline WS3 & $10 / 19 / 00$ & Brook & - & 11.5 & 9 & Liver & & & & & & \\
\hline WS3 & $10 / 19 / 00$ & Brook & - & 11.5 & 12 & Liver & & & & & & \\
\hline WS3 & $10 / 19 / 00$ & Brook & $\mathrm{F}$ & 13 & 17 & Liver & PR-WS3-B2L & 0.42 & 14.6 & 78.00 & 0.41 & 0.27 \\
\hline WS3 & $10 / 19 / 00$ & Brook & M & 18.5 & 43 & Liver & & & & & & \\
\hline WS3 & $10 / 19 / 00$ & Brook & $\mathrm{F}$ & 12 & 13 & Liver & & & & & & \\
\hline WS3 & $10 / 19 / 00$ & Brook & - & 13 & 18 & Liver & & & & & & \\
\hline WS3 & $10 / 19 / 00$ & Brook & M & 13.5 & 20 & Liver & PP-WS3-B3L & 3.35 & 14.6 & 174.30 & 0.24 & 0.31 \\
\hline WS3 & $10 / 19 / 00$ & Brook & $\mathrm{M}$ & 14.5 & 24 & Liver & & & & & & \\
\hline WS3 & $10 / 19 / 00$ & Brook & $\mathrm{F}$ & 13 & 17 & Liver & & & & & & \\
\hline WS3 & $10 / 19 / 00$ & Brook & $\mathrm{F}$ & 13 & 18 & Liver & & & & & & \\
\hline WS3 & $10 / 19 / 00$ & Brook & $\mathrm{F}$ & 13.5 & 21 & Liver & PP-WS3-B4L & 11.58 & 25.4 & 265.20 & 0.56 & 0.38 \\
\hline WS3 & $10 / 19 / 00$ & Brook & $\mathrm{F}$ & 15 & 24 & Liver & & & & & & \\
\hline WS3 & $10 / 19 / 00$ & Brook & $M$ & 14 & 23 & $P C$ & & & & & & \\
\hline WS3 & $10 / 19 / 00$ & Brook & M & 15 & 26 & PC & PP-WS3-B1P & 75.18 & 10.5 & 10.07 & 10.30 & 0.52 \\
\hline WS3 & $10 / 19 / 00$ & Brook & M & 15 & 26 & $\mathrm{PC}$ & & & & & & \\
\hline WS3 & $10 / 19 / 00$ & Brook & - & 11.5 & 9 & $P C$ & & & & & & \\
\hline WS3 & $10 / 19 / 00$ & Brook & - & 11.5 & 12 & PC & & & & & & \\
\hline WS3 & $10 / 19 / 00$ & Brook & $\mathrm{F}$ & 13 & 17 & PC & PP-WS3-B2P & 12.04 & 10.8 & 4.09 & 3.59 & 0.42 \\
\hline WS3 & $10 / 19 / 00$ & Brook & M & 18.5 & 43 & $\mathrm{PC}$ & & & & & & \\
\hline
\end{tabular}




\begin{tabular}{|c|c|c|c|c|c|c|c|c|c|c|c|c|}
\hline Site ID & Date & Species & Sex & $\mathrm{L}(\mathrm{cm})$ & wt (gm) & Type & New Id & $\mu \mathrm{g} \mathrm{As} / \mathrm{g}$ & $\mu \mathrm{g} \mathrm{Cd} / \mathrm{g}$ & $\mu \mathrm{g} \mathrm{Cu} / \mathrm{g}$ & $\mu \mathrm{g} \mathrm{Pb} / \mathrm{g}$ & $\mu \mathrm{g} \mathrm{zn} / \mathrm{g}$ \\
\hline WS3 & $10 / 19 / 00$ & Brook & $\mathrm{F}$ & 12 & 13 & $P C$ & & & & & & \\
\hline WS3 & $10 / 19 / 00$ & Brook & - & 13 & 18 & $\mathrm{PC}$ & & & & & & \\
\hline WS3 & $10 / 19 / 00$ & Brook & M & 13.5 & 20 & $\mathrm{PC}$ & PP-WS3-B3P & 49.86 & 17.3 & 6.19 & 26.10 & 0.36 \\
\hline WS3 & $10 / 19 / 00$ & Brook & M & 14.5 & 24 & $\mathrm{PC}$ & & & & & & \\
\hline WS3 & $10 / 19 / 00$ & Brook & $\mathrm{F}$ & 13 & 17 & PC & & & & & & \\
\hline WS3 & $10 / 19 / 00$ & Brook & $\mathrm{F}$ & 13 & 18 & PC & & & & & & \\
\hline WS3 & $10 / 19 / 00$ & Brook & $\mathrm{F}$ & 13.5 & 21 & PC & PP-WS3-B4P & 18.27 & 14.9 & 4.40 & 16.10 & 0.36 \\
\hline WS3 & $10 / 19 / 00$ & Brook & $\mathrm{F}$ & 15 & 24 & $\mathrm{PC}$ & & & & & & \\
\hline WS3 & $10 / 19 / 00$ & Brook & $M$ & 14 & 23 & FIL & & & & & & \\
\hline WS3 & $10 / 19 / 00$ & Brook & M & 15 & 26 & FIL & PP-WS3-B1F & 0.90 & 1.27 & 4.70 & 13.60 & 0.45 \\
\hline WS3 & $10 / 19 / 00$ & Brook & M & 15 & 26 & FIL & & & & & & \\
\hline WS3 & $10 / 19 / 00$ & Brook & - & 11.5 & 9 & FIL & & & & & & \\
\hline WS3 & $10 / 19 / 00$ & Brook & - & 11.5 & 12 & FIL & & & & & & \\
\hline WS3 & $10 / 19 / 00$ & Brook & $\mathrm{F}$ & 13 & 17 & FIL & PP-WS3-B2F & 0.73 & 0.52 & 2.11 & 1.23 & 0.53 \\
\hline WS3 & $10 / 19 / 00$ & Brook & $M$ & 18.5 & 43 & FIL & & & & & & \\
\hline WS3 & $10 / 19 / 00$ & Brook & $\mathrm{F}$ & 12 & 13 & FIL & & & & & & \\
\hline WS3 & $10 / 19 / 00$ & Brook & - & 13 & 18 & FIL & & & & & & \\
\hline WS3 & $10 / 19 / 00$ & Brook & M & 13.5 & 20 & FIL & PP-WS3-B3F & 1.95 & 0.43 & 1.55 & 0.65 & 0.45 \\
\hline WS3 & $10 / 19 / 00$ & Brook & $M$ & 14.5 & 24 & FIL & & & & & & \\
\hline WS3 & $10 / 19 / 00$ & Brook & $\mathrm{F}$ & 13 & 17 & FIL & & & & & & \\
\hline WS3 & $10 / 19 / 00$ & Brook & $\mathrm{F}$ & 13 & 18 & FIL & & & & & & \\
\hline WS3 & $10 / 19 / 00$ & Brook & $\mathrm{F}$ & 13.5 & 21 & FIL & PP-WS3-B4F & 3.05 & 0.4 & 1.43 & -0.03 & 0.29 \\
\hline WS3 & $10 / 19 / 00$ & Brook & $\mathrm{F}$ & 15 & 24 & FIL & & & & & & \\
\hline PP1 & $10 / 18 / 00$ & Brook & $\overline{\mathrm{F}}$ & 15.5 & 30 & Gill & & & & & & \\
\hline PP1 & $10 / 18 / 00$ & Brook & $\mathrm{F}$ & 17 & 40 & Gill & PP-PP1-B1G & -0.45 & 0.10 & 2.09 & 0.29 & 0.07 \\
\hline PP1 & $10 / 18 / 00$ & Brook & M & 20 & 74 & Gill & & & & & & \\
\hline PP1 & $10 / 18 / 00$ & Brook & $\mathrm{F}$ & 14.5 & 24 & Gill & & & & & & \\
\hline PP1 & $10 / 18 / 00$ & Brook & M & 18 & 52 & Gill & PP-PP1-B2G & -0.95 & 0.13 & 2.27 & 0.19 & 0.07 \\
\hline PP1 & $10 / 18 / 00$ & Brook & $M$ & 20 & 69 & Gill & & & & & & \\
\hline PP1 & $10 / 18 / 00$ & Brook & $\mathrm{F}$ & 16 & 31 & Gill & & & & & & \\
\hline PP1 & $10 / 18 / 00$ & Brook & $\mathrm{F}$ & 18 & 45 & Gill & PP-PP1-B3G & -2.33 & 0.96 & 2.21 & 0.37 & 0.09 \\
\hline PP1 & $10 / 18 / 00$ & Brook & M & 20 & 68 & Gill & & & & & & \\
\hline PP1 & $10 / 18 / 00$ & Brook & $M$ & 17 & 37 & Gill & & & & & & \\
\hline PP1 & $10 / 18 / 00$ & Brook & $\mathrm{F}$ & 18.5 & 47 & Gill & PP-PP1-B4G & 3.43 & 0.27 & 2.21 & 0.06 & 0.18 \\
\hline PP1 & $10 / 18 / 00$ & Brook & $\mathrm{F}$ & 19.5 & 61 & Gill & & & & & & \\
\hline
\end{tabular}




\begin{tabular}{|c|c|c|c|c|c|c|c|c|c|c|c|c|}
\hline Site ID & Date & Species & Sex & $L(\mathrm{~cm})$ & wt (gm) & Type & New Id & $\mu \mathrm{g} \mathrm{As} / \mathrm{g}$ & $\mu \mathrm{g} \mathrm{Cd} / \mathrm{g}$ & $\mu \mathrm{g} \mathrm{Cu} / \mathrm{g}$ & $\mu \mathrm{g} \mathrm{Pb} / \mathrm{g}$ & $\mu \mathrm{g} \mathrm{Zn} / \mathrm{g}$ \\
\hline PP1 & $10 / 18 / 00$ & Brook & $\mathrm{F}$ & 17 & 38 & Gill & & & & & & \\
\hline PP1 & $10 / 18 / 00$ & Brook & $\mathrm{F}$ & 19 & 52 & Gill & PP-PP1-B5G & 0.15 & 0.14 & 2.52 & 0.64 & 0.10 \\
\hline PP1 & $10 / 18 / 00$ & Brook & $\mathrm{M}$ & 18 & 54 & Gill & & & & & & \\
\hline PP1 & $10 / 18 / 00$ & Brook & $\bar{F}$ & 15.5 & 30 & Liver & & & & & & \\
\hline PP1 & $10 / 18 / 00$ & Brook & $\mathrm{F}$ & 17 & 40 & Liver & PP-PP1-B1L & 4.79 & 5.04 & 6.95 & 0.16 & 0.29 \\
\hline PP1 & $10 / 18 / 00$ & Brook & M & 20 & 74 & Liver & & & & & & \\
\hline PP1 & $10 / 18 / 00$ & Brook & $F$ & 14.5 & 24 & Liver & & & & & & \\
\hline PP1 & $10 / 18 / 00$ & Brook & M & 18 & 52 & Liver & PP-PP1-B2L & 1.66 & 2.87 & 6.85 & 0.18 & 0.34 \\
\hline PP1 & $10 / 18 / 00$ & Brook & M & 20 & 69 & Liver & & & & & & \\
\hline PP1 & $10 / 18 / 00$ & Brook & $\mathrm{F}$ & 16 & 31 & Liver & & & & & & \\
\hline PP1 & $10 / 18 / 00$ & Brook & $\mathrm{F}$ & 18 & 45 & Liver & PP-PP1-B3L & 0.79 & 4.77 & 9.29 & -0.17 & 0.35 \\
\hline PP1 & $10 / 18 / 00$ & Brook & M & 20 & 68 & Liver & & & & & & \\
\hline PP1 & $10 / 18 / 00$ & Brook & $M$ & 17 & 37 & Liver & & & & & & \\
\hline PP1 & $10 / 18 / 00$ & Brook & $\mathrm{F}$ & 18.5 & 47 & Liver & PP-PP1-B4L & 3.30 & 3.47 & 7.89 & 0.17 & 0.41 \\
\hline PP1 & $10 / 18 / 00$ & Brook & $\mathrm{F}$ & 19.5 & 61 & Liver & & & & & & \\
\hline PP1 & $10 / 18 / 00$ & Brook & $\mathrm{F}$ & 17 & 38 & Liver & & & & & & \\
\hline PP1 & $10 / 18 / 00$ & Brook & $\mathrm{F}$ & 19 & 52 & Liver & PP-PP1-B5L & 2.90 & 3.99 & 6.13 & 0.94 & 0.30 \\
\hline PP1 & $10 / 18 / 00$ & Brook & M & 18 & 54 & Liver & & & & & & \\
\hline PP1 & $10 / 18 / 00$ & Brook & $\bar{F}$ & 15.5 & 30 & PC & & & & & & \\
\hline PP1 & $10 / 18 / 00$ & Brook & $\mathrm{F}$ & 17 & 40 & PC & PP-PP1-B1P & 1.66 & 3.2 & 47.30 & 0.16 & 0.13 \\
\hline PP1 & $10 / 18 / 00$ & Brook & M & 20 & 74 & $\mathrm{PC}$ & & & & & & \\
\hline PP1 & $10 / 18 / 00$ & Brook & $\mathrm{F}$ & 14.5 & 24 & $P C$ & & & & & & \\
\hline PP1 & $10 / 18 / 00$ & Brook & M & 18 & 52 & $\mathrm{PC}$ & PP-PP1-B2P & 0.37 & 3.01 & 85.00 & 0.08 & 0.16 \\
\hline PP1 & $10 / 18 / 00$ & Brook & M & 20 & 69 & $\mathrm{PC}$ & & & & & & \\
\hline PP1 & $10 / 18 / 00$ & Brook & $\bar{F}$ & 16 & 31 & $\mathrm{PC}$ & & & & & & \\
\hline PP1 & $10 / 18 / 00$ & Brook & $\mathrm{F}$ & 18 & 45 & PC & PP-PP1-B3P & 2.73 & 4.66 & 62.00 & 0.49 & 0.19 \\
\hline PP1 & $10 / 18 / 00$ & Brook & M & 20 & 68 & $\mathrm{PC}$ & & & & & & \\
\hline PP1 & $10 / 18 / 00$ & Brook & $M$ & 17 & 37 & $P C$ & & & & & & \\
\hline PP1 & $10 / 18 / 00$ & Brook & $\mathrm{F}$ & 18.5 & 47 & $\mathrm{PC}$ & PP-PP1-B4P & 1.22 & 5.29 & 84.03 & 0.10 & 0.17 \\
\hline PP1 & $10 / 18 / 00$ & Brook & $\mathrm{F}$ & 19.5 & 61 & $\mathrm{PC}$ & & & & & & \\
\hline PP1 & $10 / 18 / 00$ & Brook & $\bar{F}$ & 17 & 38 & $P C$ & & & & & & \\
\hline PP1 & $10 / 18 / 00$ & Brook & $\mathrm{F}$ & 19 & 52 & $\mathrm{PC}$ & PP-PP1-B5P & -1.04 & 4.14 & 32.49 & 0.01 & 0.20 \\
\hline PP1 & $10 / 18 / 00$ & Brook & M & 18 & 54 & $\mathrm{PC}$ & & & & & & \\
\hline PP1 & $10 / 18 / 00$ & Brook & $\mathrm{F}$ & 15.5 & 30 & FIL & & & & & & \\
\hline PP1 & $10 / 18 / 00$ & Brook & $\mathrm{F}$ & 17 & 40 & FIL & PP-PP1-B1F & -0.13 & 1.67 & 3.16 & 0.68 & 0.25 \\
\hline PP1 & $10 / 18 / 00$ & Brook & M & 20 & 74 & FIL & & & & & & \\
\hline
\end{tabular}




\begin{tabular}{|c|c|c|c|c|c|c|c|c|c|c|c|c|}
\hline Site ID & Date & Species & Sex & $\mathrm{L}(\mathrm{cm})$ & wt (gm) & Type & New Id & $\mu \mathrm{g} \mathrm{As} / \mathrm{g}$ & $\mu \mathrm{g} \mathrm{Cd} / \mathrm{g}$ & $\mu \mathrm{g} \mathrm{Cu} / \mathrm{g}$ & $\mu \mathrm{g} \mathrm{Pb} / \mathrm{g}$ & $\mu \mathrm{g} \mathrm{Zn} / \mathrm{g}$ \\
\hline PP1 & $10 / 18 / 00$ & Brook & $\mathrm{F}$ & 14.5 & 24 & FIL & & & & & & \\
\hline PP1 & $10 / 18 / 00$ & Brook & M & 18 & 52 & FIL & PP-PP1-B2F & -1.82 & 6.89 & 5.12 & 0.64 & 0.31 \\
\hline PP1 & $10 / 18 / 00$ & Brook & M & 20 & 69 & FIL & & & & & & \\
\hline PP1 & $10 / 18 / 00$ & Brook & $\mathrm{F}$ & 16 & 31 & FIL & & & & & & \\
\hline PP1 & 10/18/00 & Brook & $\mathrm{F}$ & 18 & 45 & FIL & PP-PP1-B3F & -3.78 & 1.1 & 3.11 & 87.00 & 0.29 \\
\hline PP1 & $10 / 18 / 00$ & Brook & $\mathrm{M}$ & 20 & 68 & FIL & & & & & & \\
\hline PP1 & $10 / 18 / 00$ & Brook & M & 17 & 37 & FIL & & & & & & \\
\hline PP1 & $10 / 18 / 00$ & Brook & $\mathrm{F}$ & 18.5 & 47 & FIL & PP-PP1-B4F & -0.27 & 2.57 & 16.74 & 1.95 & 0.30 \\
\hline PP1 & $10 / 18 / 00$ & Brook & $\mathrm{F}$ & 19.5 & 61 & FIL & & & & & & \\
\hline PP1 & $10 / 18 / 00$ & Brook & $\mathrm{F}$ & 17 & 38 & FIL & & & & & & \\
\hline PP1 & $10 / 18 / 00$ & Brook & $\mathrm{F}$ & 19 & 52 & FIL & PP-PP1-B5F & 2.82 & 1.6 & 5.10 & 0.27 & 0.20 \\
\hline PP1 & $10 / 18 / 00$ & Brook & $\mathrm{M}$ & 18 & 54 & $\mathrm{FIL}$ & & & & & & \\
\hline PP3 & $10 / 25 / 00$ & Brook & $\mathrm{F}$ & 16 & 34 & Gill & & & & & & \\
\hline PP3 & $10 / 25 / 00$ & Brook & $\mathrm{F}$ & 17 & 50 & Gill & PP-PP3-B1G & 5.07 & 9.61 & 3.75 & 12.60 & 0.49 \\
\hline PP3 & $10 / 25 / 00$ & Brook & $\mathrm{M}$ & 21.5 & 83 & Gill & PP-PP3-B2G & 4.23 & 6.83 & 6.55 & 10.90 & 0.42 \\
\hline PP3 & $10 / 25 / 00$ & Brook & $\mathrm{F}$ & 23.5 & 92 & Gill & PP-PP3-B3G & 5.71 & 9.05 & 5.16 & 32.00 & 0.65 \\
\hline PP3 & $10 / 25 / 00$ & Brook & $\mathrm{F}$ & 24 & 101 & Gill & PP-PP3-B4G & 0.03 & 5.19 & 3.36 & 14.00 & 0.35 \\
\hline PP3 & $10 / 25 / 00$ & Brook & $\mathrm{F}$ & 16 & 34 & Liver & & & & & & \\
\hline PP3 & $10 / 25 / 00$ & Brook & $\mathrm{F}$ & 17 & 50 & Liver & PP-PP3-B1L & 1.20 & 3.83 & 68.79 & 2.02 & 0.19 \\
\hline PP3 & $10 / 25 / 00$ & Brook & $\mathrm{M}$ & 21.5 & 83 & Liver & PP-PP3-B2L & -1.65 & 5.27 & 307.39 & 8.32 & 0.26 \\
\hline PP3 & $10 / 25 / 00$ & Brook & $\mathrm{F}$ & 23.5 & 92 & Liver & PP-PP3-B3L & -0.37 & 20.5 & 1414.67 & 31.60 & 0.34 \\
\hline PP3 & $10 / 25 / 00$ & Brook & $\mathrm{F}$ & 24 & 101 & Liver & PP-PP3-B4L & 0.29 & 16.8 & 476.12 & 34.80 & 0.41 \\
\hline PP3 & $10 / 25 / 00$ & Brook & $\mathrm{F}$ & 16 & 34 & PC & & & & & & \\
\hline PP3 & $10 / 25 / 00$ & Brook & $\mathrm{F}$ & 17 & 50 & $\mathrm{PC}$ & PP-PP3-B1P & 8.75 & 22.8 & 11.48 & 55.20 & 0.61 \\
\hline PP3 & $10 / 25 / 00$ & Brook & $\mathrm{M}$ & 21.5 & 83 & $\mathrm{PC}$ & PP-PP3-B2P & 5.71 & 7.03 & 6.72 & 18.80 & 0.37 \\
\hline PP3 & $10 / 25 / 00$ & Brook & $\mathrm{F}$ & 23.5 & 92 & $\mathrm{PC}$ & PP-PP3-B3P & 4.19 & 9.09 & 11.27 & 15.60 & 0.41 \\
\hline PP3 & $10 / 25 / 00$ & Brook & $\mathrm{F}$ & 24 & 101 & $\mathrm{PC}$ & PP-PP3-B4P & 7.61 & 10.6 & 18.71 & 30.40 & 0.53 \\
\hline PP3 & $10 / 25 / 00$ & Brook & $\mathrm{F}$ & 16 & 34 & FIL & & & & & & \\
\hline PP3 & $10 / 25 / 00$ & Brook & $\mathrm{F}$ & 17 & 50 & FIL & PP-PP3-B1F & -1.35 & 0.17 & 2.40 & 0.88 & 0.13 \\
\hline PP5 & $10 / 25 / 00$ & Brook & $M$ & 21.5 & 83 & FIL & PP-PP3-B2F & -3.77 & 0.29 & 1.83 & 0.37 & 0.23 \\
\hline PP5 & $10 / 25 / 00$ & Brook & $\mathrm{F}$ & 23.5 & 92 & FIL & PP-PP3-B3F & -1.24 & 0.33 & 2.06 & 8.29 & 0.24 \\
\hline PP3 & $10 / 25 / 00$ & Brook & $\mathrm{F}$ & 24 & 101 & FIL & PP-PP3-B4F & 0.11 & 1.29 & 11.80 & 1.01 & 0.34 \\
\hline
\end{tabular}




\begin{tabular}{|c|c|c|c|c|c|c|c|c|c|c|c|c|}
\hline Site ID & Date & Species & Sex & $L(\mathrm{~cm})$ & wt (gm) & Type & New Id & $\mu \mathrm{g} \mathrm{As} / \mathrm{g}$ & $\mu \mathrm{g} \mathrm{Cd} / \mathrm{g}$ & $\mu \mathrm{g} \mathrm{Cu} / \mathrm{g}$ & $\mu \mathrm{g} \mathrm{Pb} / \mathrm{g}$ & $\mu \mathrm{g} \mathrm{Zn} / \mathrm{g}$ \\
\hline PP5 & $10 / 25 / 00$ & RBT & $\mathrm{M}$ & 23.5 & 119 & Gill & PP-PP5-RB1G & 3.11 & 1.32 & 2.61 & 4.46 & 1.01 \\
\hline PP5 & $10 / 25 / 00$ & RBT & $\mathrm{F}$ & 24.5 & 139 & Gill & PP-PP5-RB2G & 1.51 & 5.05 & 3.24 & 11.60 & 0.87 \\
\hline PP5 & $10 / 25 / 00$ & RBT & $\mathrm{F}$ & 25 & 143 & Gill & PP-PP5-RB3G & 2.52 & 5.36 & 4.75 & 2.82 & 2.51 \\
\hline PP5 & $10 / 25 / 00$ & RBT & $\mathrm{F}$ & 25.5 & 145 & Gill & PP-PP5-RB4G & 1.58 & 7.71 & 4.12 & 3.30 & 3.04 \\
\hline PP5 & $10 / 25 / 00$ & RBT & $\mathrm{F}$ & 27 & 204 & Gill & PP-PP5-RB5G & 2.55 & 2.98 & 3.51 & 6.31 & 1.65 \\
\hline PP5 & $10 / 25 / 00$ & RBT & M & 23.5 & 119 & Liver & PP-PP5-RB1L & -0.83 & 2.87 & 381.13 & 1.87 & 0.15 \\
\hline PP5 & $10 / 25 / 00$ & RBT & $\mathrm{F}$ & 24.5 & 139 & Liver & PP-PP5-RB2L & 0.14 & 3.22 & 175.13 & 1.41 & 0.13 \\
\hline PP5 & $10 / 25 / 00$ & RBT & $\mathrm{F}$ & 25.5 & 145 & Liver & PP-PP5-RB4L & 0.45 & 5.64 & 216.72 & 1.19 & 0.19 \\
\hline PP5 & $10 / 25 / 00$ & RBT & $\mathrm{F}$ & 27 & 204 & Liver & PP-PP5-RB5L & -0.97 & 1.87 & 125.60 & 1.10 & 0.08 \\
\hline PP5 & $10 / 25 / 00$ & RBT & $\mathrm{M}$ & 23.5 & 119 & $\mathrm{PC}$ & PP-PP5-RB1P & 9.62 & 3.05 & 26.15 & 6.06 & 1.68 \\
\hline PP5 & $10 / 25 / 00$ & RBT & $\mathrm{F}$ & 24.5 & 139 & $\mathrm{PC}$ & PP-PP5-RB2P & 10.16 & 5.22 & 16.25 & 11.50 & 1.44 \\
\hline PP5 & $10 / 25 / 00$ & RBT & $\mathrm{F}$ & 25 & 143 & $\mathrm{PC}$ & PP-PP5-RB3P & 5.09 & 4.89 & 9.35 & 3.76 & 0.90 \\
\hline PP5 & $10 / 25 / 00$ & RBT & $\mathrm{F}$ & 25.5 & 145 & $\mathrm{PC}$ & PP-PP5-RB4P & 8.53 & 4.19 & 23.85 & 4.76 & 2.64 \\
\hline PP5 & $10 / 25 / 00$ & RBT & $\mathrm{F}$ & 27 & 204 & $\mathrm{PC}$ & PP-PP5-RB5P & 8.10 & 2.72 & 15.15 & 8.03 & 0.66 \\
\hline PP5 & $10 / 25 / 00$ & RBT & $\mathrm{F}$ & 24.5 & 139 & FIL & PP-PP5-RB2F & 0.06 & 0.27 & 2.48 & 0.89 & 0.14 \\
\hline PP5 & $10 / 25 / 00$ & RBT & $\mathrm{F}$ & 25 & 143 & FIL & PP-PP5-RB3F & -0.49 & 0.4 & 2.94 & 0.27 & 0.16 \\
\hline PP5 & $10 / 25 / 00$ & RBT & $\mathrm{F}$ & 25.5 & 145 & $\mathrm{FIL}$ & PP-PP5-RB4F & -1.63 & 0.24 & 1.58 & -0.06 & 0.15 \\
\hline PP5 & $10 / 25 / 00$ & RBT & $\mathrm{F}$ & 27 & 204 & FIL & PP-PP5-RB5F & 1.17 & 0.11 & 2.42 & 0.29 & 0.11 \\
\hline C5 & $10 / 24 / 00$ & Brook & - & 11 & 12 & Gill & & & & & & \\
\hline $\mathrm{C} 5$ & $10 / 24 / 00$ & Brook & $\mathrm{F}$ & 22.5 & 92 & Gill & PP-C5-B1G & -1.30 & 7.85 & 19.95 & 5.20 & 0.31 \\
\hline C5 & $10 / 24 / 00$ & Brook & - & 12 & 13 & Gill & & & & & & \\
\hline $\mathrm{C} 5$ & $10 / 24 / 00$ & Brook & $\mathrm{M}$ & 21.5 & 83 & Gill & PP-C5-B2G & -1.24 & 5.32 & 5.39 & 5.28 & 0.27 \\
\hline $\mathrm{C} 5$ & $10 / 24 / 00$ & Brook & $\bar{F}$ & 12 & 14 & Gill & & & & & & \\
\hline C5 & $10 / 24 / 00$ & Brook & M & 13 & 15 & Gill & PP-C5-B3G & -3.59 & 7.16 & 4.21 & 4.27 & 0.29 \\
\hline $\mathrm{C} 5$ & $10 / 24 / 00$ & Brook & $\mathrm{F}$ & 21 & 70 & Gill & & & & & & \\
\hline C5 & $10 / 24 / 00$ & Brook & - & 11.5 & 16 & Gill & & & & & & \\
\hline C5 & $10 / 24 / 00$ & Brook & M & 13.5 & 22 & Gill & & & & & & \\
\hline C5 & $10 / 24 / 00$ & Brook & - & 14.5 & 25 & Gill & PP-C5-B4G & -2.50 & 5.76 & 4.98 & 3.47 & 0.35 \\
\hline C5 & $10 / 24 / 00$ & Brook & $\mathrm{M}$ & 14 & 25 & Gill & & & & & & \\
\hline C5 & $10 / 24 / 00$ & Brook & M & 13 & 19 & Gill & & & & & & \\
\hline
\end{tabular}




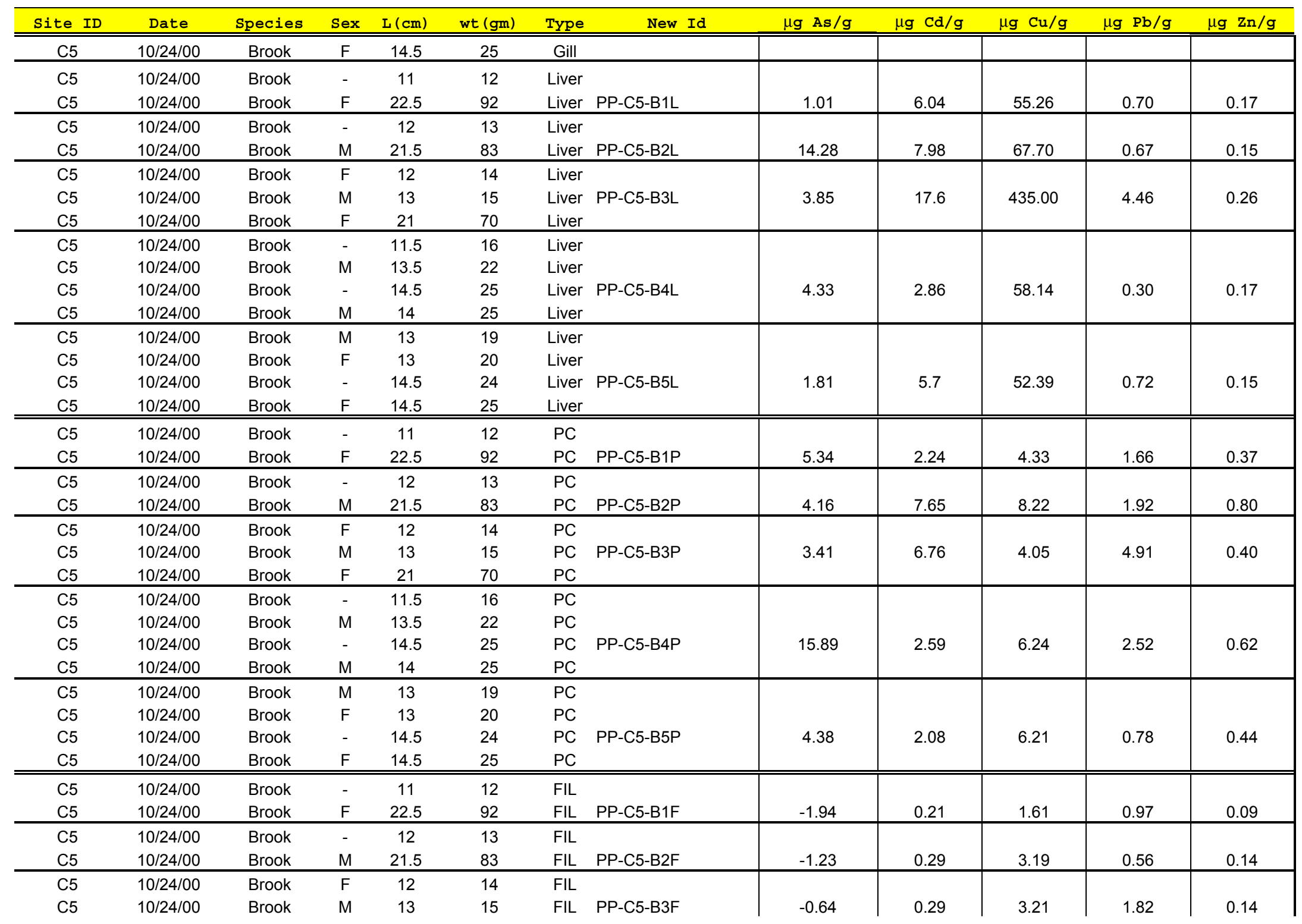




\begin{tabular}{|c|c|c|c|c|c|c|c|c|c|c|c|c|}
\hline Site ID & Date & Species & Sex & $\mathrm{L}(\mathrm{cm})$ & wt (gm) & Type & New Id & $\mu \mathrm{g} \mathrm{As} / \mathrm{g}$ & $\mu \mathrm{g} \mathrm{Cd} / \mathrm{g}$ & $\mu \mathrm{g} \mathrm{Cu} / \mathrm{g}$ & $\mu \mathrm{g} \mathrm{Pb} / \mathrm{g}$ & $\mu \mathrm{g} \mathrm{Zn} / \mathrm{g}$ \\
\hline $\mathrm{C} 5$ & $10 / 24 / 00$ & Brook & $\mathrm{F}$ & 21 & 70 & FIL & & & & & & \\
\hline $\mathrm{C5}$ & $10 / 24 / 00$ & Brook & - & 11.5 & 16 & FIL & & & & & & \\
\hline C5 & $10 / 24 / 00$ & Brook & $M$ & 13.5 & 22 & FIL & & & & & & \\
\hline C5 & $10 / 24 / 00$ & Brook & - & 14.5 & 25 & FIL & PP-C5-B4F & -1.90 & 0.1 & 2.00 & 0.71 & 0.08 \\
\hline $\mathrm{C} 5$ & $10 / 24 / 00$ & Brook & M & 14 & 25 & FIL & & & & & & \\
\hline $\mathrm{C5}$ & $10 / 24 / 00$ & Brook & $M$ & 13 & 19 & FIL & & & & & & \\
\hline $\mathrm{C} 5$ & $10 / 24 / 00$ & Brook & $\mathrm{F}$ & 13 & 20 & FIL & & & & & & \\
\hline C5 & $10 / 24 / 00$ & Brook & - & 14.5 & 24 & FIL & PP-C5-B5F & -2.22 & 0.42 & 1.47 & 0.63 & 0.08 \\
\hline $\mathrm{C} 5$ & $10 / 24 / 00$ & Brook & $\mathrm{F}$ & 14.5 & 25 & FIL & & & & & & \\
\hline L5 & $10 / 17 / 00$ & Brook & $M$ & 13 & 15 & Gill & & & & & & \\
\hline L5 & $10 / 17 / 00$ & Brook & - & 16.5 & 31 & Gill & PP-L5-B1G & -4.87 & 3.22 & 4.57 & 2.03 & 0.38 \\
\hline L5 & $10 / 17 / 00$ & Brook & $\mathrm{M}$ & 16.5 & 39 & Gill & & & & & & \\
\hline L5 & $10 / 17 / 00$ & Brook & - & 13.5 & 18 & Gill & & & & & & \\
\hline L5 & $10 / 17 / 00$ & Brook & M & 14 & 29 & Gill & PP-L5-B2G & -3.28 & 3.74 & 5.28 & 0.99 & 0.30 \\
\hline L5 & $10 / 17 / 00$ & Brook & M & 16.5 & 39 & Gill & & & & & & \\
\hline L5 & $10 / 17 / 00$ & Brook & - & 14 & 20 & Gill & & & & & & \\
\hline L5 & $10 / 17 / 00$ & Brook & M & 16 & 29 & Gill & PP-L5-B3G & -5.55 & 2.95 & 5.40 & 1.11 & 0.31 \\
\hline L5 & $10 / 17 / 00$ & Brook & M & 17 & 38 & Gill & & & & & & \\
\hline L5 & $10 / 17 / 00$ & Brook & $M$ & 14 & 23 & Gill & & & & & & \\
\hline L5 & $10 / 17 / 00$ & Brook & M & 14.5 & 28 & Gill & PP-L5-B4G & -2.45 & 2.71 & 4.14 & 0.78 & 0.33 \\
\hline L5 & $10 / 17 / 00$ & Brook & $\mathrm{M}$ & 17 & 34 & Gill & & & & & & \\
\hline L5 & $10 / 17 / 00$ & Brook & $M$ & 15 & 28 & Gill & & & & & & \\
\hline L5 & $10 / 17 / 00$ & Brook & $M$ & 15.5 & 31 & Gill & PP-L5-B5G & 1.46 & 3.12 & 4.39 & 3.56 & 0.43 \\
\hline L5 & $10 / 17 / 00$ & Brook & $\mathrm{M}$ & 16 & 33 & Gill & & & & & & \\
\hline L5 & $10 / 17 / 00$ & Brook & $M$ & 13 & 15 & Liver & & & & & & \\
\hline L5 & $10 / 17 / 00$ & Brook & - & 16.5 & 31 & Liver & PP-L5-B1L & 2.11 & 5.75 & 67.73 & 0.67 & 0.10 \\
\hline L5 & $10 / 17 / 00$ & Brook & M & 16.5 & 39 & Liver & & & & & & \\
\hline L5 & $10 / 17 / 00$ & Brook & - & 13.5 & 18 & Liver & & & & & & \\
\hline L5 & $10 / 17 / 00$ & Brook & M & 14 & 29 & Liver & PP-L5-B2L & 1.42 & 7.22 & 57.38 & 1.14 & 0.20 \\
\hline L5 & $10 / 17 / 00$ & Brook & $M$ & 16.5 & 39 & Liver & & & & & & \\
\hline L5 & $10 / 17 / 00$ & Brook & - & 14 & 20 & Liver & & & & & & \\
\hline L5 & $10 / 17 / 00$ & Brook & M & 16 & 29 & Liver & PP-L5-B3L & 1.75 & 3.74 & 110.53 & 1.58 & 0.23 \\
\hline L5 & $10 / 17 / 00$ & Brook & M & 17 & 38 & Liver & & & & & & \\
\hline L5 & $10 / 17 / 00$ & Brook & $M$ & 14 & 23 & Liver & & & & & & \\
\hline L5 & $10 / 17 / 00$ & Brook & M & 14.5 & 28 & Liver & PP-L5-B4L & 2.25 & 4.24 & 60.35 & 4.65 & 0.13 \\
\hline L5 & $10 / 17 / 00$ & Brook & $\mathrm{M}$ & 17 & 34 & Liver & & & & & & \\
\hline L5 & $10 / 17 / 00$ & Brook & $M$ & 15 & 28 & Liver & & & & & & \\
\hline
\end{tabular}




\begin{tabular}{|c|c|c|c|c|c|c|c|c|c|c|c|c|}
\hline Site ID & Date & Species & Sex & $\mathrm{L}(\mathrm{cm})$ & wt (gm) & Type & New Id & $\mu \mathrm{g}$ As $/ \mathrm{g}$ & $\mu \mathrm{g} \mathrm{Cd} / \mathrm{g}$ & $\mu \mathrm{g} \mathrm{Cu} / \mathrm{g}$ & $\mu \mathrm{g} \mathrm{Pb} / \mathrm{g}$ & $\mu \mathrm{g} \mathrm{zn} / \mathrm{g}$ \\
\hline L5 & $10 / 17 / 00$ & Brook & $M$ & 15.5 & 31 & Liver & PP-L5-B5L & 2.36 & 7.61 & 136.38 & 0.02 & 0.20 \\
\hline L5 & $10 / 17 / 00$ & Brook & $\mathrm{M}$ & 16 & 33 & Liver & & & & & & \\
\hline L5 & $10 / 17 / 00$ & Brook & $\mathrm{M}$ & 13 & 15 & PC & & & & & & \\
\hline L5 & $10 / 17 / 00$ & Brook & - & 16.5 & 31 & PC & PP-L5-B1P & -2.70 & 10.9 & 23.88 & 56.90 & 0.88 \\
\hline L5 & $10 / 17 / 00$ & Brook & $\mathrm{M}$ & 16.5 & 39 & $\mathrm{PC}$ & & & & & & \\
\hline L5 & $10 / 17 / 00$ & Brook & - & 13.5 & 18 & PC & & & & & & \\
\hline L5 & $10 / 17 / 00$ & Brook & $M$ & 14 & 29 & PC & PP-L5-B2P & 1.77 & 10.4 & 5.50 & 0.13 & 0.41 \\
\hline L5 & $10 / 17 / 00$ & Brook & $\mathrm{M}$ & 16.5 & 39 & $\mathrm{PC}$ & & & & & & \\
\hline L5 & $10 / 17 / 00$ & Brook & - & 14 & 20 & PC & & & & & & \\
\hline L5 & $10 / 17 / 00$ & Brook & $M$ & 16 & 29 & PC & PP-L5-B3P & 2.61 & 269 & 6.82 & 0.72 & 0.38 \\
\hline L5 & $10 / 17 / 00$ & Brook & $\mathrm{M}$ & 17 & 38 & $\mathrm{PC}$ & & & & & & \\
\hline L5 & $10 / 17 / 00$ & Brook & $M$ & 14 & 23 & PC & & & & & & \\
\hline L5 & $10 / 17 / 00$ & Brook & $M$ & 14.5 & 28 & PC & PP-L5-B4P & 0.10 & 4.71 & 7.28 & 0.24 & 0.33 \\
\hline L5 & $10 / 17 / 00$ & Brook & $\mathrm{M}$ & 17 & 34 & $\mathrm{PC}$ & & & & & & \\
\hline L5 & $10 / 17 / 00$ & Brook & $M$ & 15 & 28 & $P C$ & & & & & & \\
\hline L5 & $10 / 17 / 00$ & Brook & $M$ & 15.5 & 31 & PC & PP-L5-B5P & 2.57 & 4.26 & 7.35 & 0.04 & 0.45 \\
\hline L5 & $10 / 17 / 00$ & Brook & $\mathrm{M}$ & 16 & 33 & $\mathrm{PC}$ & & & & & & \\
\hline L5 & $10 / 17 / 00$ & Brook & $M$ & 13 & 15 & FIL & & & & & & \\
\hline L5 & $10 / 17 / 00$ & Brook & - & 16.5 & 31 & FIL & PP-L5-B1F & -1.85 & 0.1 & 1.86 & 1.23 & 0.13 \\
\hline L5 & $10 / 17 / 00$ & Brook & $\mathrm{M}$ & 16.5 & 39 & FIL & & & & & & \\
\hline L5 & $10 / 17 / 00$ & Brook & - & 13.5 & 18 & FIL & & & & & & \\
\hline L5 & $10 / 17 / 00$ & Brook & $M$ & 14 & 29 & FIL & PP-L5-B2F & -0.06 & 0.25 & 1.94 & 1.57 & 0.21 \\
\hline L5 & $10 / 17 / 00$ & Brook & $\mathrm{M}$ & 16.5 & 39 & FIL & & & & & & \\
\hline L5 & $10 / 17 / 00$ & Brook & - & 14 & 20 & FIL & & & & & & \\
\hline L5 & $10 / 17 / 00$ & Brook & $M$ & 16 & 29 & FIL & PP-L5-B3F & -0.19 & 0.15 & 1.52 & 0.61 & 0.20 \\
\hline L5 & $10 / 17 / 00$ & Brook & $\mathrm{M}$ & 17 & 38 & FIL & & & & & & \\
\hline L5 & $10 / 17 / 00$ & Brook & $M$ & 14 & 23 & FIL & & & & & & \\
\hline L5 & $10 / 17 / 00$ & Brook & $M$ & 14.5 & 28 & FIL & PP-L5-B4F & -2.59 & 0.65 & 2.35 & 0.60 & 0.17 \\
\hline L5 & $10 / 17 / 00$ & Brook & $\mathrm{M}$ & 17 & 34 & FIL & & & & & & \\
\hline L5 & $10 / 17 / 00$ & Brook & M & 15 & 28 & FIL & & & & & & \\
\hline L5 & $10 / 17 / 00$ & Brook & $M$ & 15.5 & 31 & FIL & PP-L5-B5F & -0.72 & 0.44 & 2.11 & 2.92 & 0.20 \\
\hline L5 & $10 / 17 / 00$ & Brook & $\mathrm{M}$ & 16 & 33 & FIL & & & & & & \\
\hline
\end{tabular}




\section{Whole Fish}

\begin{tabular}{|c|c|c|c|c|c|c|c|c|c|c|c|c|}
\hline Site ID & Date & Species & Sex & $L(\mathrm{~cm})$ & wt (gm) & Sample ID & Type & $\mu \mathrm{g}$ As $/ \mathrm{g}$ & $\mu \mathrm{g} \mathrm{Cd} / \mathrm{g}$ & $\mu \mathrm{g} \mathrm{Cu} / \mathrm{g}$ & $\mu \mathrm{g} \quad \mathrm{Pb} / \mathrm{g}$ & $\mu \mathrm{g} \mathrm{zn} / \mathrm{g}$ \\
\hline WS3 & $10 / 19 / 00$ & Brook & & 13 & 16 & WS3-WF-1 & WF & 5.47 & 3.26 & 12.48 & 3.12 & 0.46 \\
\hline WS3 & $10 / 19 / 00$ & Brook & & 13.5 & 21 & WS3-WF-2 & WF & 4.03 & 3 & 41.22 & 1.60 & 0.30 \\
\hline WS3 & $10 / 19 / 00$ & Brook & & 14 & 22 & WS3-WF-3 & WF & 4.83 & 1.66 & 9.04 & 2.48 & 0.43 \\
\hline wS3 & $10 / 19 / 00$ & Brook & & 12.5 & 15 & WS3-WF-4 & WF & 4.75 & 1.74 & 44.10 & 1.68 & 0.33 \\
\hline WS3 & $10 / 19 / 00$ & Brook & & 12.5 & 14 & WS3-WF-5 & WF & 3.09 & 3 & 49.60 & 1.37 & 0.64 \\
\hline PP1 & $10 / 18 / 00$ & Brook & $\bar{M}$ & 22 & 102 & PP1-WF-1 & WF & 0.06 & 0.33 & 3.30 & 0.55 & 0.09 \\
\hline PP1 & $10 / 18 / 00$ & Brook & $\mathrm{F}$ & 20 & 72 & PP1-WF-2 & WF & -0.69 & 0.49 & 16.98 & 0.02 & 0.11 \\
\hline PP1 & $10 / 18 / 00$ & Brook & & 13.5 & 22 & PP1-WF-3 & WF & 0.06 & 0.39 & 8.57 & 0.10 & 0.12 \\
\hline PP1 & $10 / 18 / 00$ & Brook & & 17 & 38 & PP1-WF-4 & WF & -0.25 & 0.59 & 33.03 & 0.17 & 0.08 \\
\hline PP1 & $10 / 18 / 00$ & Brook & & 17 & 38 & PP1-WF-5 & WF & 1.76 & 0.73 & 41.55 & 0.12 & 0.11 \\
\hline PP3 & $10 / 25 / 00$ & Brook & & 16.5 & 41 & PP3-WF-1 & WF & 0.03 & 0.61 & 4.03 & 3.50 & 0.21 \\
\hline PP3 & $10 / 25 / 00$ & Brook & & 17.5 & 56 & PP3-WF-2 & WF & 0.03 & 0.68 & 17.79 & 3.32 & 0.24 \\
\hline PP3 & $10 / 25 / 00$ & Brook & & 18 & 58 & PP3-WF-3 & WF & 0.24 & 0.83 & 12.72 & 3.67 & 0.33 \\
\hline PP3 & $10 / 25 / 00$ & Brook & & 10 & 8 & PP3-WF-4 & WF & 5.34 & 1.32 & 32.24 & 20.30 & 0.30 \\
\hline PP3 & $10 / 25 / 00$ & Brook & & 9.5 & 6 & PP3-WF-5 & WF & 1.58 & 0.66 & 15.19 & 0.61 & 0.17 \\
\hline PP5 & $10 / 25 / 00$ & RBT & & 19 & 63 & PP5-WF-1 & WF & 0.99 & 0.21 & 9.95 & 2.24 & 0.15 \\
\hline PP5 & $10 / 25 / 00$ & RBT & & 21.5 & 84 & PP5-WF-2 & WF & 0.84 & 0.4 & 14.15 & 22.80 & 0.22 \\
\hline PP5 & $10 / 25 / 00$ & RBT & & 24 & 124 & PP5-WF-3 & WF & 0.78 & 0.22 & 7.05 & 1.79 & 0.10 \\
\hline PP5 & $10 / 25 / 00$ & RBT & & 19.5 & 65 & PP5-WF-4 & WF & 1.62 & 0.19 & 6.05 & 2.67 & 0.20 \\
\hline PP5 & $10 / 25 / 00$ & RBT & & $?$ & $?$ & PP5-WF-5 & WF & 2.32 & 0.3 & 17.90 & 4.67 & 0.23 \\
\hline $\mathrm{C} 5$ & $10 / 24 / 00$ & $\overline{\text { Brook }}$ & & 13 & 19 & C5-WF-1 & WF & 2.33 & 0.79 & 16.81 & 3.22 & 0.16 \\
\hline C5 & $10 / 24 / 00$ & Brook & & 16 & 32 & C5-WF-2 & WF & 0.49 & 0.59 & 14.62 & 4.36 & 0.15 \\
\hline C5 & $10 / 24 / 00$ & Brook & & 13.5 & 19 & C5-WF-3 & WF & 2.83 & 0.5 & 10.02 & 0.69 & 0.14 \\
\hline C5 & $10 / 24 / 00$ & Brook & & 11.5 & 13 & C5-WF-4 & WF & 3.77 & 0.66 & 21.16 & 0.88 & 0.10 \\
\hline $\mathrm{C} 5$ & $10 / 24 / 00$ & Brook & & 12.5 & 15 & C5-WF-5 & WF & -1.22 & 0.42 & 11.17 & 0.68 & 0.15 \\
\hline $\bar{L} 5$ & $10 / 17 / 00$ & Brook & & 13.5 & 17 & L5-WF-1 & WF & 0.41 & 0.54 & 10.62 & 0.13 & 0.40 \\
\hline L5 & $10 / 17 / 00$ & Brook & & 14.5 & 22 & L5-WF-2 & WF & -0.02 & 0.86 & 15.59 & 0.36 & 0.35 \\
\hline L5 & $10 / 17 / 00$ & Brook & & 14.5 & 23 & L5-WF-3 & WF & -1.14 & 0.98 & 31.50 & -0.09 & 0.39 \\
\hline L5 & $10 / 17 / 00$ & Brook & & 13.5 & 19 & L5-WF-4 & WF & 0.06 & 1.85 & 83.82 & 0.46 & 0.42 \\
\hline L5 & $10 / 17 / 00$ & Brook & & 14 & 20 & L5-WF-5 & WF & 1.20 & 1.25 & 12.76 & 0.34 & 0.55 \\
\hline
\end{tabular}

